\title{
Photolabile Linkers for Solid-Phase Synthesis
}

\author{
Mikkelsen, Remi J. T.; Grier, Katja E.; Mortensen, Kim T.; Nielsen, Thomas .; Qvortrup, Katrine
}

Published in:

A C S Combinatorial Science

Link to article, DOI:

10.1021/acscombsci.8b00028

Publication date:

2018

Document Version

Peer reviewed version

Link back to DTU Orbit

Citation (APA):

Mikkelsen, R. J. T., Grier, K. E., Mortensen, K. T., Nielsen, T. ., \& Qvortrup, K. (2018). Photolabile Linkers for Solid-Phase Synthesis. A C S Combinatorial Science, 20(7), 377-399.

https://doi.org/10.1021/acscombsci.8b00028

\section{General rights}

Copyright and moral rights for the publications made accessible in the public portal are retained by the authors and/or other copyright owners and it is a condition of accessing publications that users recognise and abide by the legal requirements associated with these rights.

- Users may download and print one copy of any publication from the public portal for the purpose of private study or research.

- You may not further distribute the material or use it for any profit-making activity or commercial gain

- You may freely distribute the URL identifying the publication in the public portal

If you believe that this document breaches copyright please contact us providing details, and we will remove access to the work immediately and investigate your claim 


\section{Review}

Subscriber access provided by DTU Library

\section{Photolabile Linkers for Solid-Phase Synthesis \\ Remi Jacob Thomsen Mikkelsen, Katja Egeskov Grier, Kim \\ Thollund Mortensen, Thomas Eiland Nielsen, and Katrine Qvortrup}

ACS Comb. Sci., Just Accepted Manuscript • DOI: 10.1021/acscombsci.8b00028 • Publication Date (Web): 04 Jun 2018

Downloaded from http://pubs.acs.org on June 13, 2018

\section{Just Accepted}

"Just Accepted" manuscripts have been peer-reviewed and accepted for publication. They are posted online prior to technical editing, formatting for publication and author proofing. The American Chemical Society provides "Just Accepted" as a service to the research community to expedite the dissemination of scientific material as soon as possible after acceptance. "Just Accepted" manuscripts appear in full in PDF format accompanied by an HTML abstract. "Just Accepted" manuscripts have been fully peer reviewed, but should not be considered the official version of record. They are citable by the Digital Object Identifier (DOI®). "Just Accepted" is an optional service offered to authors. Therefore, the "Just Accepted" Web site may not include all articles that will be published in the journal. After a manuscript is technically edited and formatted, it will be removed from the "Just Accepted" Web site and published as an ASAP article. Note that technical editing may introduce minor changes to the manuscript text and/or graphics which could affect content, and all legal disclaimers and ethical guidelines that apply to the journal pertain. ACS cannot be held responsible for errors or consequences arising from the use of information contained in these "Just Accepted" manuscripts. 


\title{
Photolabile Linkers for Solid-Phase Synthesis
}

\author{
Remi J. T. Mikkelsen ${ }^{\dagger}$, Katja E. Grier ${ }^{\dagger}$, Kim T. Mortensen ${ }^{\dagger}$, and Thomas E. Nielsen ${ }^{*}+,, \infty$, Katrine \\ Qvortrup $^{* \dagger}$ \\ ${ }^{\dagger}$ Department of Chemistry, Technical University of Denmark, DK-2800 Kgs. Lyngby, Denmark. \\ $\$$ Singapore Centre for Environmental Life Sciences Engineering, Nanyang Technological \\ University, Singapore 637551, Singapore. \\ a Costerton Biofilm Center, Department of Immunology and Microbiology, University of \\ Copenhagen, DK-2200 Copenhagen N, Denmark.
}

\begin{abstract}
KEYWORDS. Solid-phase synthesis, photolabile linker, combinatorial chemistry, chemical biology.
\end{abstract}

\begin{abstract}
Photolabile linkers are the subjects of intense research, because they allow the release of the target molecule simply by irradiation. Photochemical release of synthesis products is often facilitated without additional reagents under mild reaction conditions, which may even be environmentally friendly and appealing in the context of greener chemistry. The mild conditions also allow for applications of released material in subsequent biological screening experiments, where contamination with cleavage reagents would be detrimental. This review pays attention to the increasing number of photolabile linkers developed for solid-phase synthesis and release, and covers: (i) $o$-nitrobenzyloxy linkers, (ii) $o$-nitrobenzylamino linkers,
\end{abstract}


(iii) $\alpha$-substituted $o$-nitrobenzyl linkers, (iv) $o$-nitroveratryl linkers, (v) phenacyl linkers, (vi) $p$ alkoxyphenacyl linkers, (vii) benzoin linkers, (viii) pivaloyl linkers, (ix) other photolabile linkers.

\section{INTRODUCTION}

Originally pioneered by Merrifield for the synthesis of peptides,[1] solid-phase organic synthesis (SPOS) is a well-established technique that offers unique advantages over conventional solution-phase methods. With experimental simplicity, reactions are driven to completion with excessive amounts of reagent, and even highly polar and polymeric organic compounds are readily handled through multiple reaction steps, and easily isolated following release of product from the solid support. Since the introduction of solid-phase methods half a century ago, many laboratories have focused on the development of technologies and chemistry suitable for solidphase synthesis, which has resulted in a remarkable outburst of chemical transformations that can be applied for the routine synthesis of organic molecules on solid support.[2, 3, 4, 5, 6] This has led to the application of solid-phase synthesis for the generation of molecular libraries in academia and industry to identify new bio-active molecules, drugs, catalysts and other fine chemicals.[7, 8] Solid-phase synthesis is the cornerstone of combinatorial chemistry, either through the generation of nucleic acid libraries for biological display, or in in-bead based splitpool approaches.

The use of solid supports in organic synthesis relies on several interconnected requirements. The substrate containing multiple chemical handles must be attached to the solid support, and then modified through multiple chemical transformations before controlled release 
of the target product. Conventional linkers normally used in SPOS typically rely on harsh cleavage conditions, comprising strong acids, bases or nucleophiles, which can pose compatibility problems with more sensitive molecular structures. Inherently, the range of chemical transformations available for the synthesis of any given compound is restricted by linker. Photolysis offers a method of linker cleavage, which is fully orthogonal to conventional chemical methods and therefore, holds a unique promise for applying an expanded range of chemical transformations to build structurally diverse compounds on solid support. Photolabile linkers generally do not need acidic, basic or metal-assisted activation for cleavage, and photochemical substrate release is often facilitated without additional reagents under mild reaction conditions, that may even be environmentally friendly and appealing in the context of greener chemistry. The mild conditions may, furthermore, become attractive for applications of released crude material in subsequent biological screening experiments, where contamination with cleavage reagents would be detrimental. Recent advances in LED lighting technology have significantly increased the ease with which photochemical transformations may be achieved, and the field has witnessed a markedly increased interest in recent years. Herein, we provide an extensive overview of the synthesis and applications of photolabile linkers for solid-phase synthesis.

\title{
PHOTOLABILE LINKERS
}

\section{o-Nitrobenzyloxy linkers}

\author{
Nitrobenzyl-based linkers are often considered the most commonly used linkers. Their \\ cleavage mechanism is traditionally identified as a Norrish type II reaction, as the \\ photochemistry was described by Norrish in 1935.[9] Norrish demonstrated that an incident
}


photon (300-350 $\mathrm{nm})$ breaks the $\mathrm{N}=\mathrm{O} \pi$-bond in the nitro-group, forming a diradical excited state. During the photoisomerization, the activated oxygen of the nitro group abstracts a proton from the benzylic position, forming the aci-nitro compound, which subsequently rearranges to afford an $o$-nitrosobenzaldehyde, thereby releasing the product (Figure 1).<smiles>[R]C(Cl)c1cc(O)ccc1[N+](=O)[O-]</smiles><smiles>[R]C(=O)c1cc(Oc2ccc([N+](=O)[O-])c([2H])c2)ccc1O</smiles>

Figure 1. Norrish Type II mechanism for the photo cleavage of a 2-nitrobenzyl-based linker.

Overall, nitrobenzyl-based linkers are highly general, and the list of functional groups that can be released are now extensive. The scope includes, but is not limited to phosphates, carboxylates, carbonates, carbamates, and alkoxides. Research efforts towards raising the chemical and quantum yields of nitrobenzyl-based linkers have led to the identification of several benificial modifications, which will be disscussed in the following sections.

The first reported example of a photolabile linker was the o-nitrobenzyloxy based resin pioneered by Rich and Gurwara in 1973.[10] The resin was contructed using a Friedel-Craftstype chloromethylation of the aromatic rings of polymer 1, cf. Scheme 1. A nitration, as described by Merrifield,[1] made the resin ready for attachment of th first amino acid at the $C$ terminus affording 3. After standard SPPS, photolysis released the first peptide constructed on a photolabile linker in a yield of $62 \%$. 


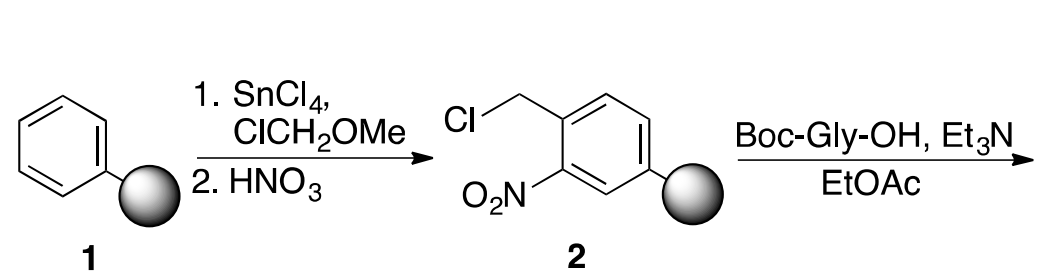

Boc
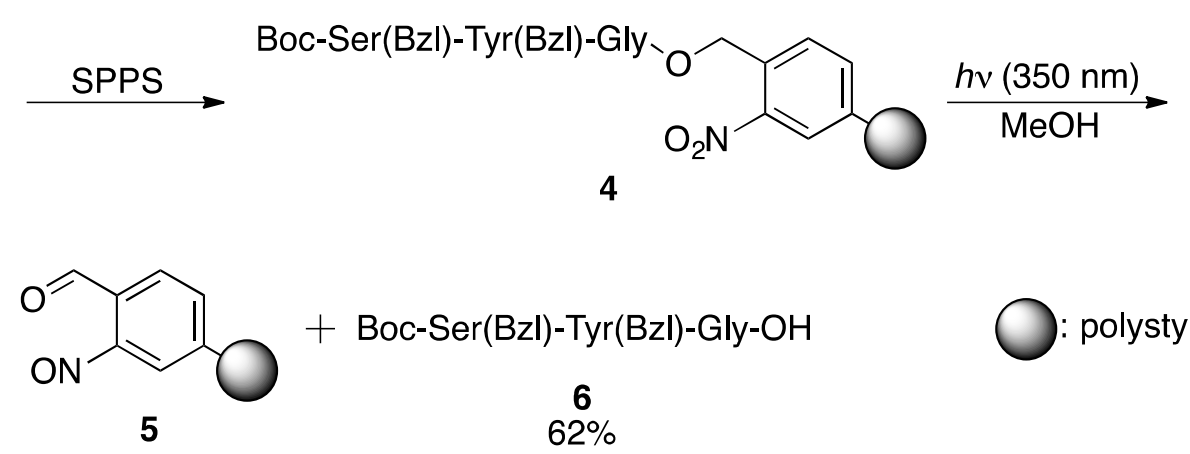

polystyrene resin

Scheme 1. First solid-phase synthesis and application of a photolabile linker based on the $o$ nitrobenzyloxy functional group.

However, it became clear that this strategy was not applicable to the synthesis of peptides incorporating more than four amino acids.[11] Over-nitration of the resin apparently caused enhanced polarity of the resin resulting in reduced swelling in organic solvents. In an attempt to find a solution to this limitation, a new strategy was developed where the linker $\mathbf{8}$ was prepared separately and then coupled to the resin,[11] cf. Scheme 2. Construct 9 was then set up for attachment of the first amino acid and following standard SPPS, the decapeptide $\mathbf{1 1}$ was released in $64 \%$ yield. 

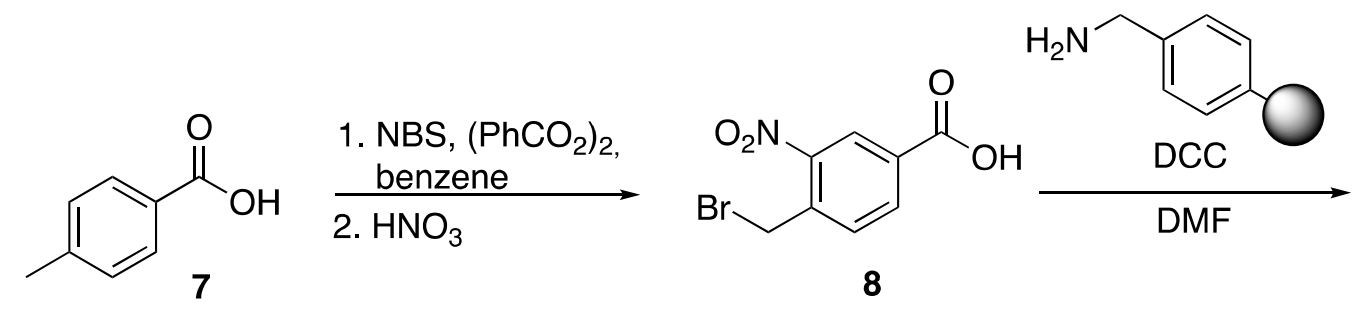

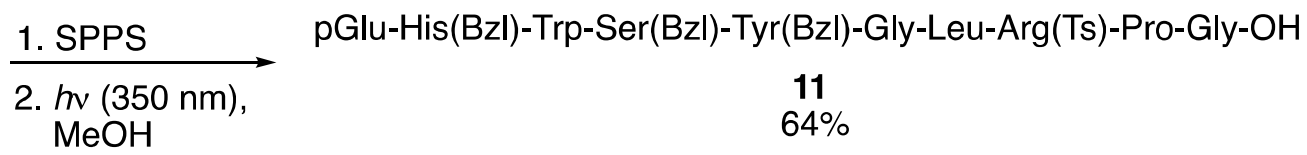

: polystyrene resin

Scheme 2. Synthesis and application of an $o$-nitrobenzyloxy linker.

Later, Merrifield and coworkers have used linker 8 for the preparation of multi-detachable resins $[12,13]$. Barany and Albericio have applied the linker in an orthogonal protection group scheme for solid-phase organic synthesis [14], where the photolabile construct 12 contained a phenolic $t$-butyl group and a dithiasuccinoyl $N$ - $\alpha$ amino protecting group, both of which are photochemically inert and mutually orthogonal (Scheme 3).<smiles></smiles>

polystyrene resin

Scheme 3. Three-dimensional and orthogonal protection of a resin-bound peptide. 
Different variations of this linker construct have been explored, e.g. with a phenyl group in the benzylic position, $[15,16]$ or a glycine unit as an internal standard.[17] Pillai et al. has also reported use of the o-nitrobenzyloxy linker with a PEG spacer in between the photolabile cleavage site and the solid support.[18] In a study aiming for the synthesis of encoded small molecule libraries, Ohlmeyer and coworkers used the $o$-nitrobenzyloxy linker to facilitate easy release of the synthesized compounds under conditions optimal for direct use in biological assays.[19]

In 1993 Greenberg and coworkers demonstrated the application of $o$-nitrobenzyloxy-based linkers for oligonucleotide synthesis.[20, 21, 22] A DCC-mediated coupling of succinatothymidine 13 to the trichlorophenyl ester $\mathbf{1 4}$, followed by coupling to a long-chain alkyl amine controlled pore glass, LCAA-CPG, support in the presence of HOBt led to construct $\mathbf{1 5}$, which allowed for the synthesis of oligonucleotides (Scheme 4).

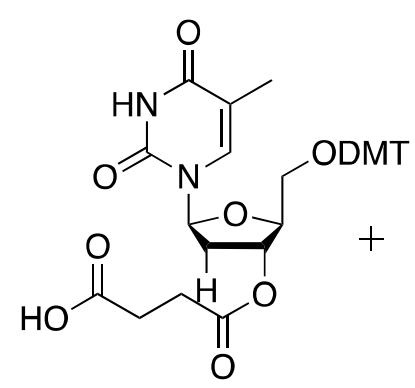

13<smiles>O=C(Oc1cc(Cl)c(Cl)cc1Cl)c1ccc(CO)c([N+](=O)[O-])c1</smiles>

14

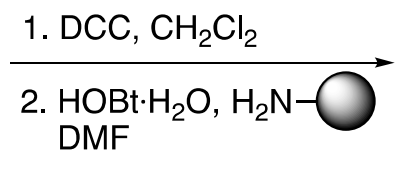<smiles>COOCC1OC2OC1C(n1cc(C)c(=O)[nH]c1=O)C2CCC(=O)OCc1ccc(C(=O)Nc2ccccc2)cc1[N+](=O)[O-]</smiles>

15

Scheme 4. Solid-phase oligonucleotide synthesis using a photolabile linker.

Alcohol-containing groups can also be attached to a $o$-nitrobenzyloxy linker as either carbonates,[23] or ethers,[24] for example in oligosaccharide synthesis. In pioneering work by Zehavi et al.,[25] however, a rather low isolated yield of oligosaccharides was obtained (e.g. 0.87 $\%$ of 16, Scheme 5). The low yield was ascribed to low accessibility of amine handles in the 
aminoethyl substituted polyacrylamide gel resin used. Later, Nicolaou et al.,[26, 27] Kantchev and Parquette[28] demonstrated the use of the $o$-nitrobenzyloxy linker in oligosaccharide synthesis, allowing for a higher isolated yield of the desired oligosaccharides.

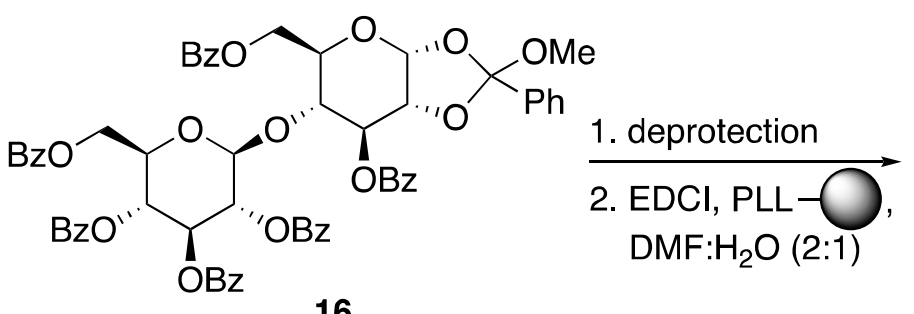

16<smiles>O=C(Nc1ccc([18OH])cc1)c1ccc(CO[AlH2])c([N+](=O)[O-])c1</smiles>

18

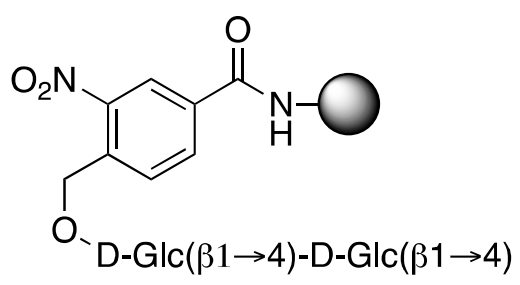

17

$\underset{\text { UDP-Gal, D-galactosyltransferase }}{\stackrel{\text { sodium cacodylate buffer }}{\longrightarrow}}$

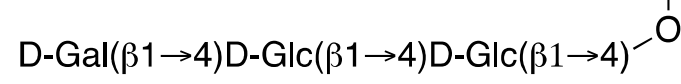

$$
\text { D-Gal }(\beta 1 \rightarrow 4) D-G l c(\beta 1 \rightarrow 4) D-G l c(\alpha / \beta)
$$

19
$0.87 \%$

: polyacrylamide gel resin

Scheme 5. Oligosaccharide synthesis utilizing a photolabile $o$-nitrobenzyloxy linker.

Using the linker construct 14, amines can be attached through a carbamate moiety as shown by Armstrong et al. for combinatorial library synthesis using the Passerini reaction (Scheme 6).[29] 
<smiles>O=C(Oc1cc(Cl)c(Cl)cc1Cl)c1ccc(CO)c([N+](=O)[O-])c1</smiles><smiles>CCOC(=O)CNC(=O)OCc1ccc(C(=O)Oc2cc(Cl)c(Cl)cc2Cl)cc1[N+](=O)[O-]</smiles>

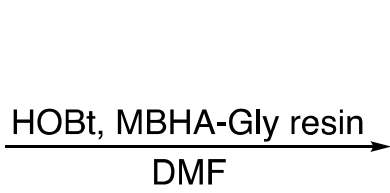<smiles>COC(=O)NCC(=O)O</smiles><smiles>N#Cc1ccccc1</smiles>
18<smiles>CCCC=CCCC(=O)OC</smiles>

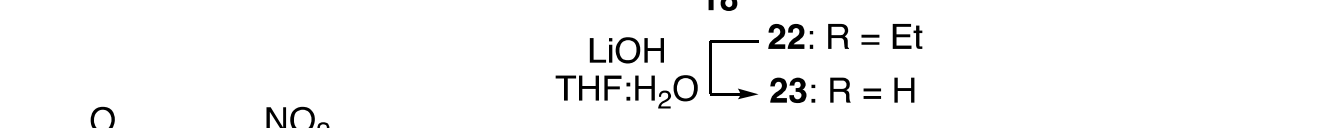<smiles>CCCC(OC(=O)CNC(=O)OCc1ccc(C(=O)NCC(C)=O)cc1[N+](=O)[O-])C(=O)NCC(=O)OC</smiles><smiles>c1ccccc1</smiles><smiles>CCCC(OC(=O)CNC(C)=O)C(=O)NCC(=O)OC</smiles>

: methylbenzhydrylamine resin

Scheme 6. Photolabile $o$-nitrobenzyloxy linker attached to an amine through a carbamate moiety.

\section{2-(2-Nitrophenyl)propyloxycarbonyl (NPPOC) linker}

To lower the photolysis time required for efficient cleavage compared to $o$-nitrobenzyl linkers, Damha et al. hypothesized that extending the chain containing the reactive hydroxyl handle by one carbon atom and branching it to generate a tertiary benzylic carbon center would be beneficial.[30] The effects of a substituent in the benzylic position are consistent with the relative rates of hydrogen abstraction from alkyl carbon by a photo-activated $o$-nitro group: primary $<$ secondary $<$ tertiary. 
To investigate this feature, Damha et al. prepared linker 28. [30] Starting from 26, linker 28 was synthesized in two steps followed by attachment to the solid support (Scheme 7). With construct 29 in hand, Damha synthesized a library of oligoribonucleotides and found that the target molecules indeed were photolytically released from the linker in only 15 minutes at room temperature.<smiles>CCOC(=O)c1ccc(C(C)COOC(F)(F)F)c([N+](=O)[O-])c1</smiles><smiles>CC(COOC(F)(F)F)c1ccc(C(=O)O)cc1[N+](=O)[O-]</smiles>
28

: LCAA-CPG<smiles>CC(COC(F)F)c1ccc(C(=O)Nc2ccccc2)cc1[N+](=O)[O-]</smiles>
29

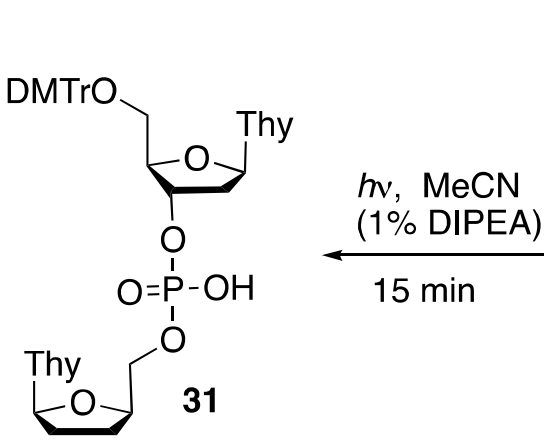

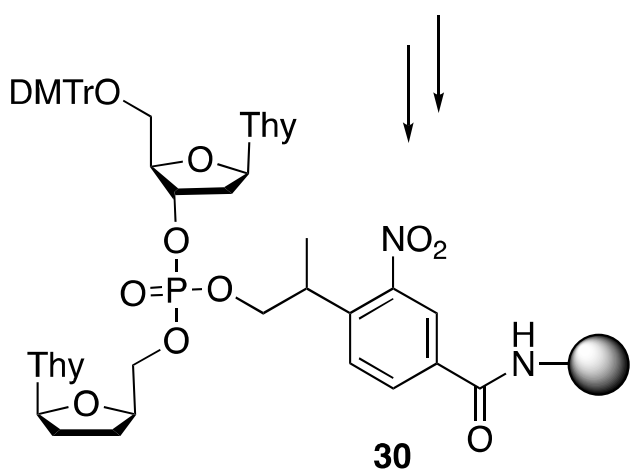

Scheme 7. Photolabile $o$-nitrobenzyloxy linker for incorporation of a tertiary benzylic carbon.

Despite the structural similarity between $o$-nitrobenzyl linkers and $\mathbf{2 8}$, the release mechanism differs markedly. The generated aci-nitro intermediate rearranges to $o$-nitrostyrene with $\beta$ elimination of the linker group,[31] as illustrated in Figure 2. 


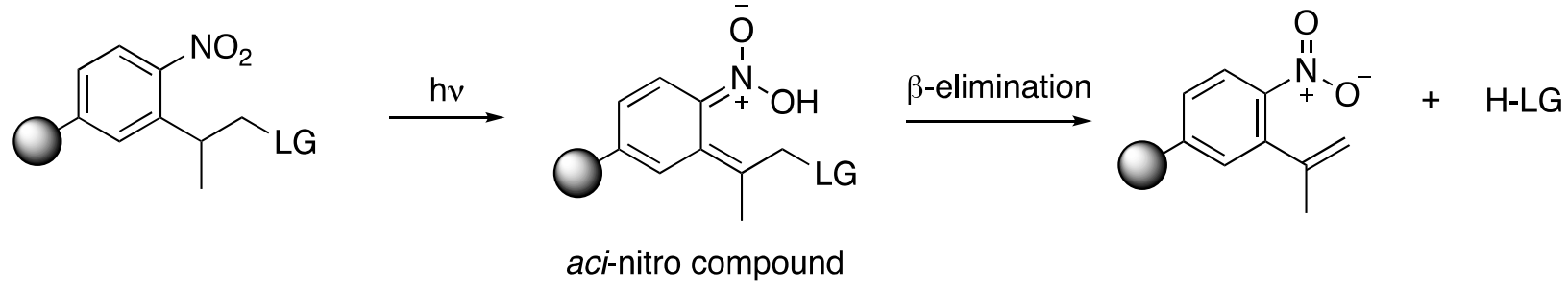

Figure 2. Mechanism for the photocleavage of NPPOC derivatives.

\section{o-Nitrobenzylamino linkers}

Taking into account that many biologically active peptides possess a $c$-terminal primary amide, Rich and Gurwara developed a variation of the $o$-nitrobenzyl-based linker that upon photolysis releases amides (Scheme 8).[32]. Starting from $p$-toluic acid, bromination followed by nitration led to $\mathbf{8}$. The bromide $\mathbf{8}$ was then aminated and immediately Boc-protected using Boc-azide to furnish 32. After attachment to the resin and deprotection, Boc-Val-OH was attached. After photolysis Boc-Val- $\mathrm{NH}_{2}$ (35) was provided in quantitative yield. Furthermore, it was shown that a decapeptide could be prepared and released in high purity and good yield (65\%). Another synthetic route to provide $\mathbf{3 2}$ from 4-aminomethylbenzoic acid was presented by Barany and coworkers.[33] Ajayaghosh and Pillai demonstrated the possibility of releasing secondary amides by substituting the linker precursor $\mathbf{8}$ (or the corresponding chloride) with a primary amine instead of ammonia.[34, 35, 36] Hinterstein, et al. used an $o$-nitrobenzylamino linker in their on-bead screening of a one-bead one-compound library in the search for nuclear import inhibitors.[37] 

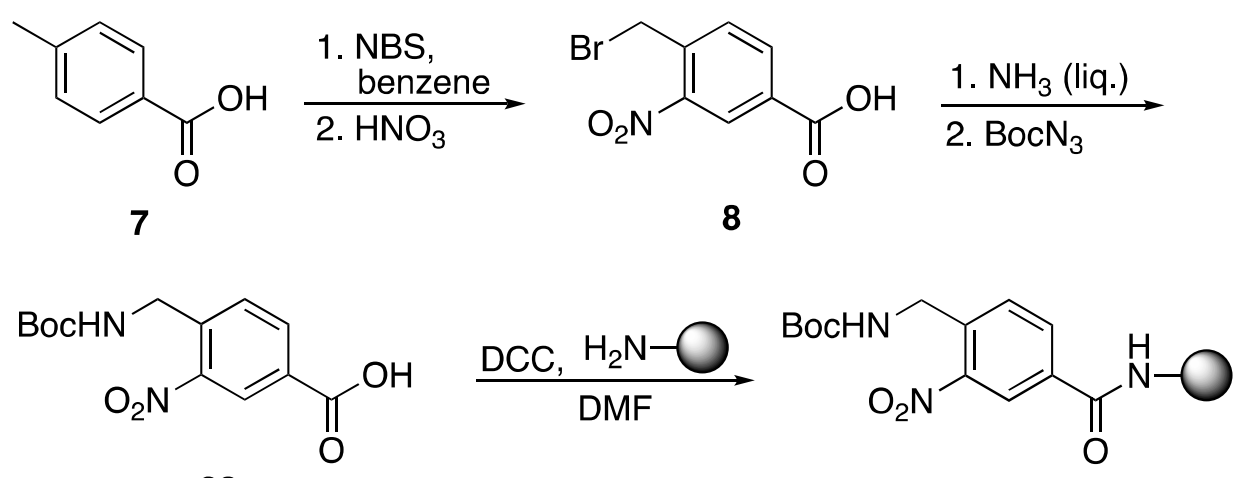

32

33

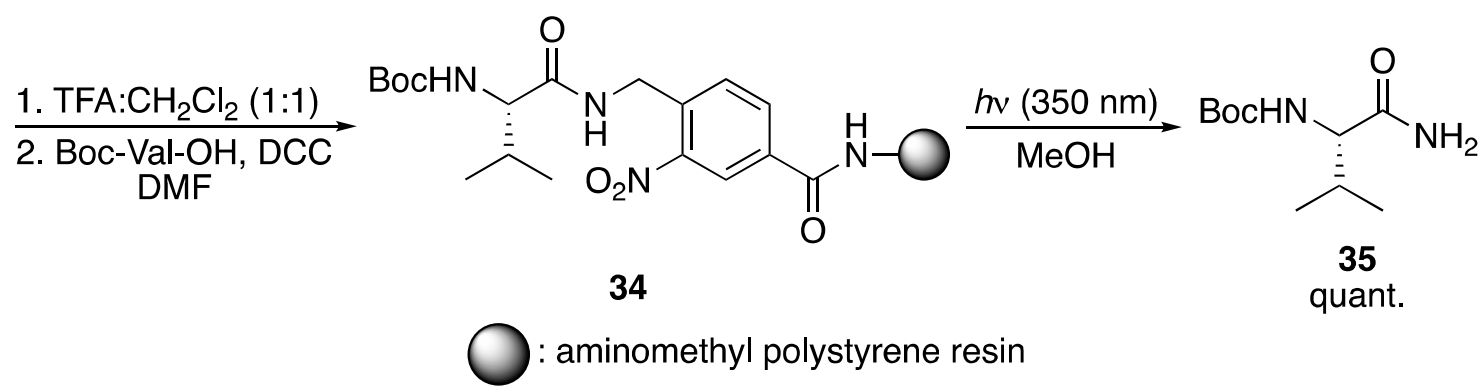

Scheme 8. Photolabile $o$-nitrobenzylamino linker for release of amides.

Recently, Seeberger and coworkers developed an approach for the automated synthesis of glucosaminoglycans utilizing an $o$-nitrobenzylamino linker.[38] Iterative cycles of coupling carbohydrate building blocks $\mathbf{3 7}$ and $\mathbf{3 8}$ to the linker construct 36, yielded, in 16 steps, the hexasaccharide $\mathbf{4 0}$ in 13\% yield after photoclevage in a continuous flow photoreactor, cf. scheme 9. 
<smiles>O=C(OCc1ccccc1)N(CCCCCO)Cc1cc(O)ccc1[N+](=O)[O-]</smiles>

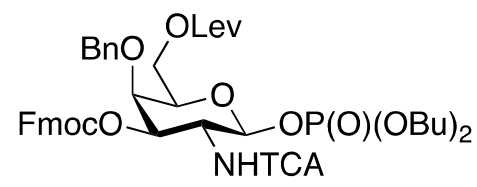
NHTCA

37

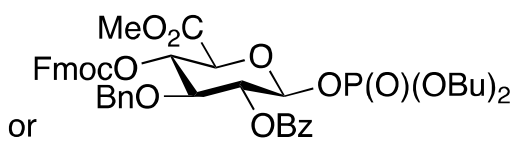

38

coupling of carbohydrate building block 


\section{a-Substituted $o$-nitrobenzyl linkers}

The $o$-nitrobenzyl-based linkers presented so far suffer from disadvantageous formation of side products, such as o-nitrosobenzaldehyde, which is a very reactive species prone to polymerization, forming a highly colored product, which may act as an undesired internal light filter that affects the efficiency of the photolytic release.[41] To solve this issue, Ajayaghosh and Pillai prepared resin $\mathbf{4 3}$, featuring a secondary benzyl alcohol as reactive handle for peptide attachment (Scheme 10).[41]

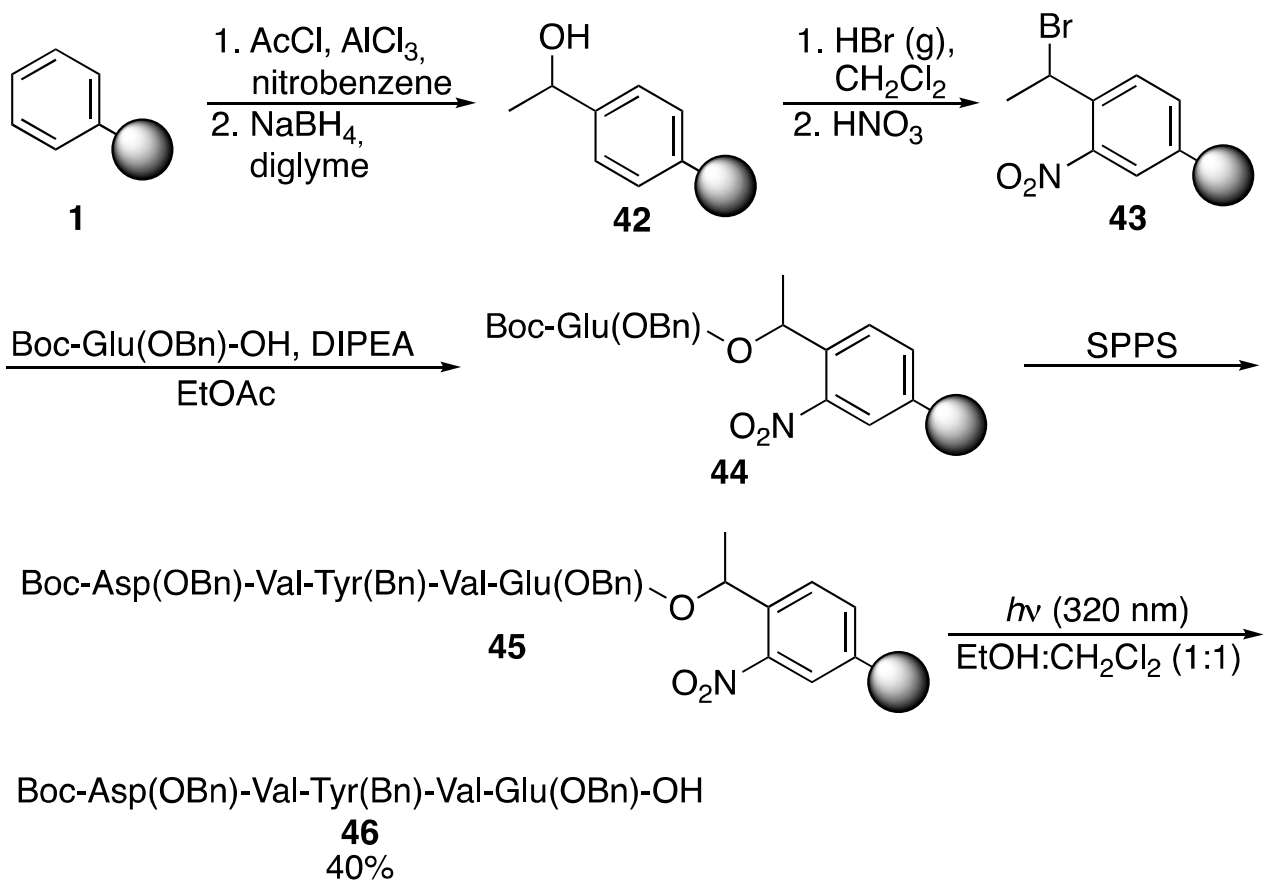

: polystyrene resin

Scheme 10. Integral $\alpha$-substituted nitrobenzyl-derived photolabile linker used for the synthesis of pentapeptide 46.

Resin 1 was subjected to Friedel-Crafts-type acylation, followed by reduction to the alcoholfunctionalized resin $\mathbf{4 2}$, which after substitution and nitration was transformed into the bromofunctionalized integral linker 43. This linker was used for the synthesis of pentapeptide 46 in a yield of $40 \%$. This resin, however, suffered from problems similar to those observed with Rich 
and Gurwara's original o-nitrobenzyloxy linker (Scheme 1). Over-nitration destroyed the swelling properties of the resin and prevented the synthesis of longer peptides.

A solution to this issue is to introduce the support itself in the benzylic position instead of a methyl group (Scheme 11).[42] The resin 1 underwent Friedel-Crafts acylation followed by reduction leading to $o$-nitrobenzhydryl resin 48. With this resin in hand, Ajayaghosh and Pillai synthesized peptides $\mathbf{4 9}$ [42] and, after transformation to the amine-functionalized resin $\mathbf{5 0 , [ 4 3 ] ~}$ the corresponding amidopeptides 51. Peptides with up to 10 amino acids were synthesized in good yields.

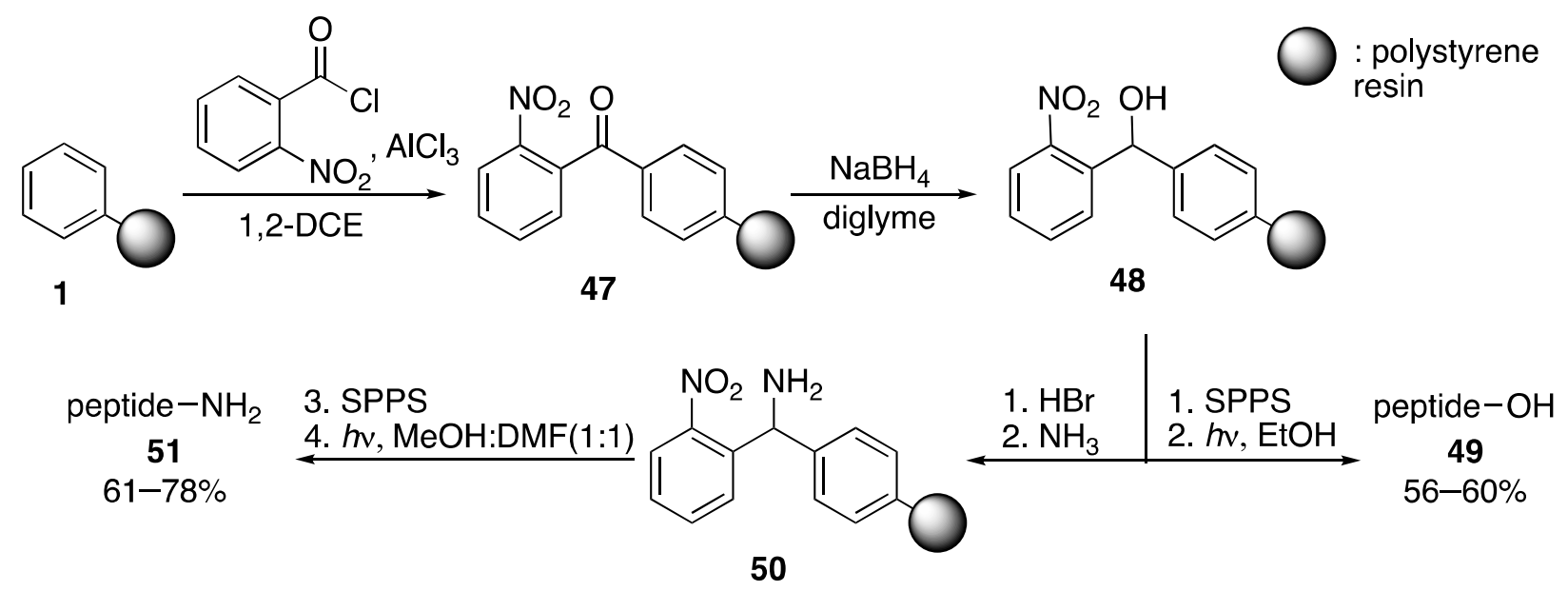

Scheme 11. $o$-Nitrobenzhydryl resin for the synthesis of peptides and amido peptide.

The related 3-amino-3-(2-nitrophenyl)propionyl (ANP) linker $\mathbf{5 3}$ was developed by Geysen and coworkers for the synthesis of peptide amides (Scheme 12).[44] Sternson and Schreiber demonstrated a more acid-stable variant established with two methyl groups in the $\alpha$-position of the carboxylic acid handle.[45] Geysen and coworkers demonstrated the use of an alcoholfunctionalized variant of the linker for oligosaccharide synthesis.[46] A longer spacer was incorporated between the support and the photosensitive part to avoid problems with $\beta$ elimination and lactonization of the alcohol. 
<smiles>O=Cc1ccccc1[N+](=O)[O-]</smiles>

52
1. $\mathrm{CH}_{2}(\mathrm{COOH})_{2}$, $\mathrm{NH}_{4} \mathrm{OAc}, \mathrm{AcOH}$ 2. $\mathrm{FmocOSu}, \mathrm{Et}_{3} \mathrm{~N}$ $\mathrm{MeCN}: \mathrm{H}_{2} \mathrm{O}(1: 1)$<smiles>CCCNC(CC(=O)O)c1ccccc1[N+](=O)[O-]</smiles>

53

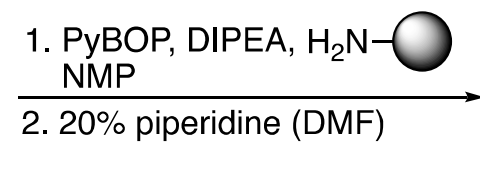
NMP<smiles>NC(CC(=O)Nc1ccccc1)c1ccccc1[N+](=O)[O-]</smiles>

$\underset{\text { 1. SPPS }}{2 . h v(365 \mathrm{~nm}),}$
$\underset{\mathrm{H}_{2} \mathrm{O}}{\longrightarrow}$$\quad \begin{gathered}\text { Fmoc-Asp-Arg(Ts)-Val- } \mathrm{NH}_{2} \\ 55\end{gathered}$

Scheme 12. Synthesis of photolabile ANP resin used for the synthesis of amidopeptide $\mathbf{5 5}$.

An alternate route to similar linkers was designed by Ryba and Harran to access hydroxyl (60) and amino-containing variants (61), respectively, both from the ketone 56 (Scheme 13).[47]

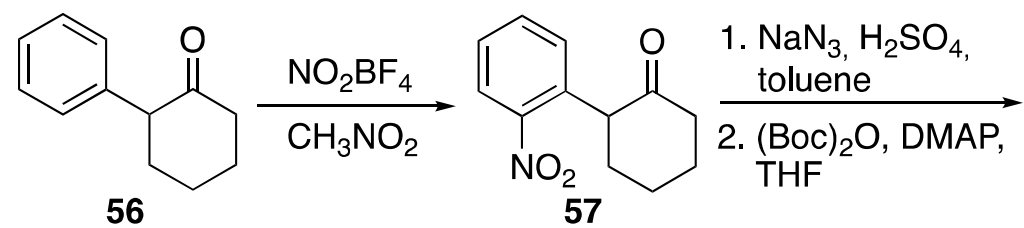<smiles>O=C1CCCCC(c2ccccc2[N+](=O)[O-])O1</smiles>

59

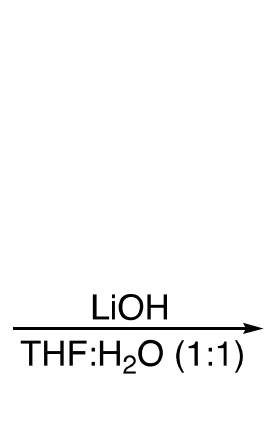<smiles>[R]C(CCCCC(=O)O)c1ccccc1[N+](=O)[O-]</smiles>

60: $\mathrm{R}=\mathrm{OH}$

61: $R=N H B o c$

Scheme 13. Synthesis of photolabile ANP type linkers.

\section{o-Nitroveratryl linkers}

First introduced by Zehavi and Patchornik,[48] the use of the $o$-nitroveratryl group (4,5dimethoxy-2-nitrobenzyl) in photolabile linkers was popularized in the mid-1990s by Yoo and Greenberg,[49] and Holmes and Jones.[50]

Yoo and Greenberg utilized the linker construct to circumvent some of the issues encountered with the original, unsubstituted $o$-nitrobenzyl linker, namely long photolysis times and low yields 
of release.[48] The synthesis of linker 64 started from vanillin (62), which after etherification and nitration provided the aldehyde 63, cf. Scheme 14. After a few functional group interconversions, linker 64 was obtained.[48]

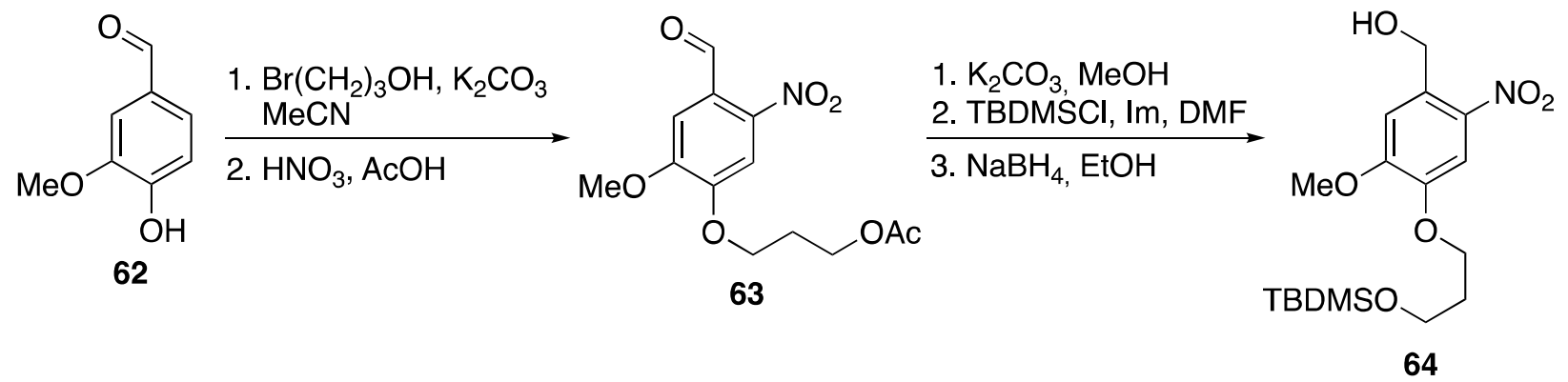

Scheme 14. Synthesis of photolabile $o$-nitroveratryl-based linker.

Linker 64 can readily be installed on a LCAA-CPG support as construct $\mathbf{6 7}$, which was used for the synthesis and release of oligonucleotides in good yields (Scheme 15).[48] Later, it was shown that a more efficient photolysis was achieved when the hydroxyl group of the nucleotide was attached directly to the linker via a carbonate group.[51] Initiated by these studies, this linker has been more broadly implemented in oligonucleotide synthesis.[52] 
<smiles>COc1cc(CO)c([N+](=O)[O-])cc1OCCCOCC(=O)OCC(=O)OCC(C)(C)C</smiles>

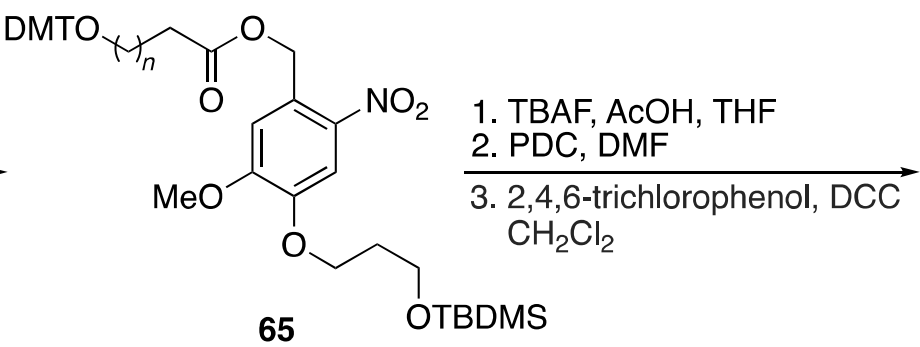<smiles>COc1cc(COC(=O)CNOC(C)(F)F)c([N+](=O)[O-])cc1OCCC(=O)Oc1c(Cl)cc(Cl)cc1Cl</smiles>

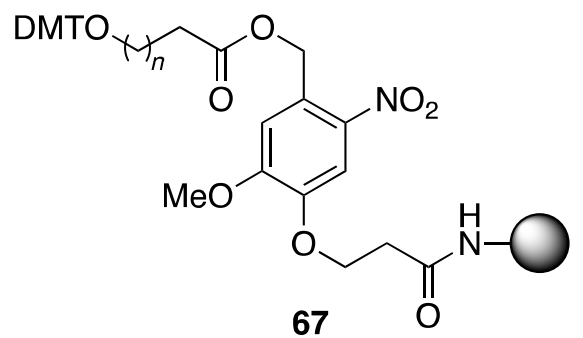

1. oligonucleotide synthesis 2. $h v(400 \mathrm{~nm}), \mathrm{MeCN}: \mathrm{H}_{2} \mathrm{O}(9: 1)$ 3. detritylation $\left(\mathrm{NH}_{4} \mathrm{OH}, \mathrm{aq}\right)$

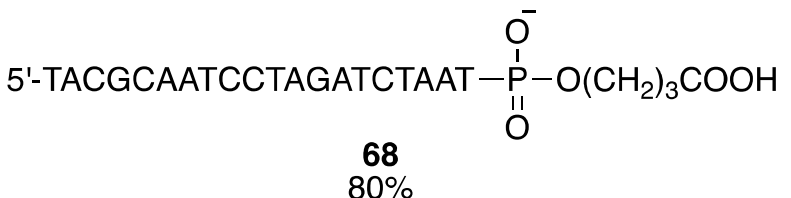

\section{: $\mathrm{LCAA}-\mathrm{CPG}$}

Scheme 15. Use of photolabile $o$-nitroveratryl-based linker for the synthesis of oligonucleotides.

Holmes and Jones introduced an $o$-nitroveratryl-based amine linker with a methyl group in the a-position.[49] This linker, producing amides upon photolysis, also solved the problem relating to formation of reactive nitroso aldehydes upon photolysis, as described earlier. The synthesis from acetovanillone (69) provided linker $\mathbf{7 4}$ after a 7-step sequence. Linker $\mathbf{7 4}$ was then used for the synthesis of hexapeptide 76 in a yield of 70\% (Scheme 16). 


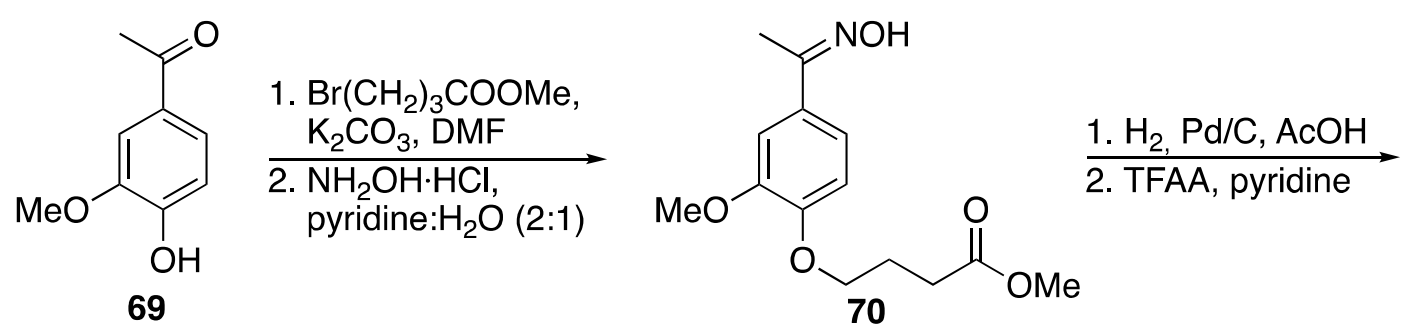

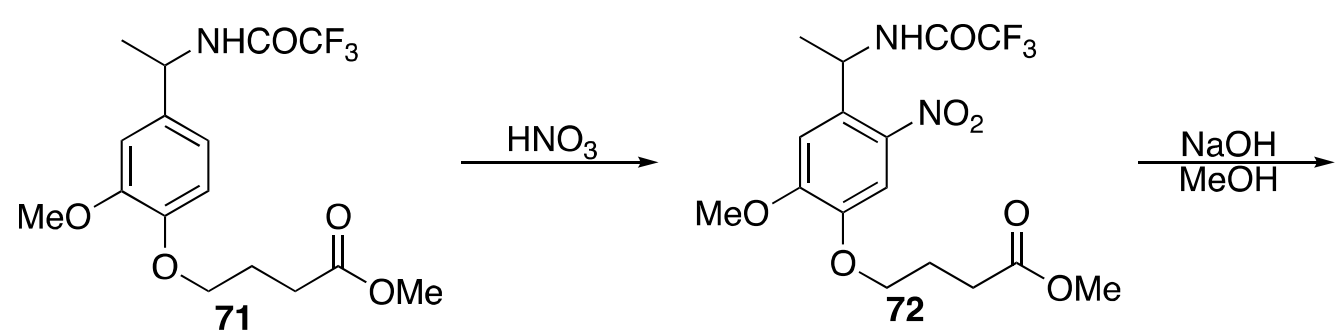<smiles>COc1cc(C(C)N)c([N+](=O)[O-])cc1OCCCC(=O)O</smiles><smiles>COc1cc(C(C)N)c([N+](=O)[O-])cc1OCCCC(=O)NO</smiles>

\section{SPPS}

2. $h v(365 \mathrm{~nm})$, PBS buffer:DMSO (95:5)

76

H-Met-Gly-Trp-Met-Asp-Phe- $\mathrm{NH}_{2}$ $70 \%$

\section{Q: TentaGel resin}

Scheme 16. Synthesis of photolabile amine-containing $\alpha$-methylated nitroveratryl linker and its use for the synthesis of a hexapeptide.

In 1997, Holmes published a systematic study of the effect of nitroveratryl substituents on the photolysis efficiency.[53] It was shown that the rate of cleavage was 7 to 20 times higher when the $o$-nitrobenzyl ring was substituted with electron-donating alkoxy substituents. It was also shown that an alkyl group in the amine $\alpha$-position increased the rate by a factor of 3 . The length of the spacer chain also influenced the release rate with a slight increase for longer chains. It was 
concluded that both the alkoxy substituents on the aromatic ring and the alkyl group in the $\alpha$ position were beneficial for the photochemical reactivity.

Holmes also developed an alcohol-based version of the linker 74,[53] which was synthesized analogously to the corresponding amine linker (Scheme 17).
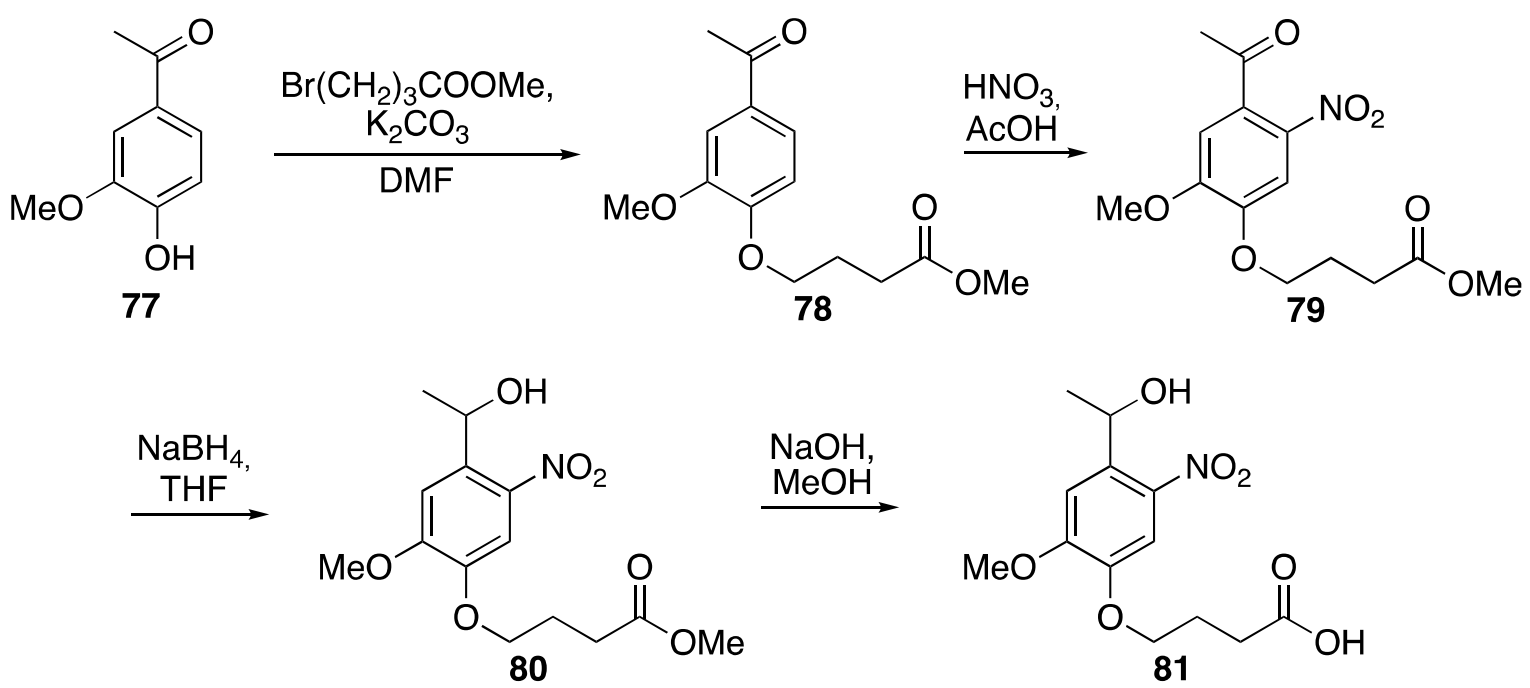

Scheme 17. Synthesis of photolabile alcohol-containing $\alpha$-methylated nitroveratryl linker

Although, this was a useful route for the synthesis of 81, problems were encountered in the nitration of 78, due to contamination with substantial quantities of the ipso substitution of the acetyl group. An improved synthetic pathway to give the ester $\mathbf{8 0}$ was developed by Teague.[54] Ipso substitution was substantially reduced, when nitration was performed at low temperature with fuming nitric acid.

The linkers $\mathbf{7 4}$ and $\mathbf{8 1}$ have been used for numerous applications, and it has been shown that such linkers may be coupled to hydroxyl-based resin without effecting the efficiency of the photolytic cleavage.[55] An o-nitroveratryl linker was used by McKeown et al. to develop methods for easing the analysis of solid-phase synthesis reactions by mass spectrometric techniques.[56] Another example is the use of linker 74 by Madder for the preparation of serine protease mimics.[57] Lin and Blackwell used this linker for the synthesis of a diketopiperazine 
library using the Ugi multi-component reaction (Scheme 18).[58] The linker $\mathbf{7 4}$ was attached to a solid support and subsequent coupling of Fmoc-Phe $\left(4-\mathrm{NO}_{2}\right)-\mathrm{OH}$ and Fmoc deprotection under standard SPPS conditions led to the construct 82. Ugi reactions, followed by methanolysis and photochemical release afforded diketopiperazines $\mathbf{8 4}$ in moderate to good purities.<smiles>COc1cc(C(C)N)c([N+](=O)[O-])cc1OCCCC(=O)Nc1ccc(OC)c([N+](=O)[O-])c1</smiles><smiles>[R]C(N)C(=O)NC(C)c1cc(OC)c(OCCCC(=O)Nc2ccccc2)cc1[N+](=O)[O-]</smiles>

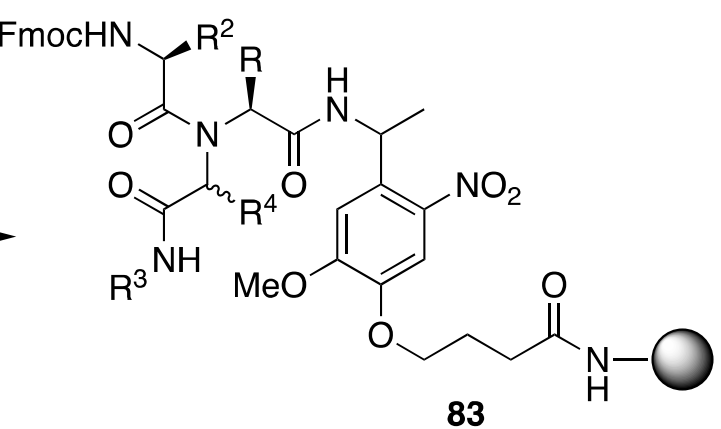

1. $10 \% \mathrm{AcCl}(\mathrm{MeOH})$ 2. $20 \%$ piperidine (DMF)

3. $h v(366 \mathrm{~nm})$, $\mathrm{MeOH}$<smiles>[R]C1NC(=O)C([R7])N(C([R])C(N)=O)C1=O</smiles>

$53-91 \%$ purity<smiles>CCc1ccc([N+](=O)[O-])cc1</smiles>

$\mathrm{R}^{2}$ : amino acid side chain

$\mathrm{R}^{3}$ :<smiles>CC(C)(C)C1=CCCCC1</smiles>

$\mathrm{R}^{4}: \mathrm{Cy}, \mathrm{CH}_{3}\left(\mathrm{CH}_{2}\right)_{5}, \mathrm{Ph}\left(\mathrm{CH}_{2}\right)_{2}$

: modified cellulose

Scheme 18. $o$-Nitroveratryl linker used in multicomponent reactions by Lin and Blackwell. 
Gennari et al. used the linker $\mathbf{7 4}$ for the synthesis of a combinatorial library of vinylogous sulfonamidopeptides.[59] This study confirmed the trends encountered by Holmes,[53] namely that $o$-nitroveratryl-based linkers are superior to $o$-nitrobenzyl linkers, due to the beneficial effects of alkoxy-substituents and the presence of a $\alpha$-methyl group.

Another example is the synthesis of 3,4-disubstituted $\beta$-lactams by Gallop and coworkers (Scheme 19).[60] The construct 75 was condensed with an aldehyde to form imines 85 which then underwent a [2+2] cycloaddition with a ketene to provide 86 . Finally, photolysis led to $\beta$ lactams 87 in good yields (Scheme 19).[60].<smiles>COc1cc(C(C)N)c([N+](=O)[O-])cc1OCCCC(=O)Nc1ccccc1</smiles><smiles>C=[Al]CCCC(OC)OC</smiles><smiles>[R]C=NC(C)c1cc(OC)c(OCCCC(=O)Nc2ccccc2)cc1[N+](=O)[O-]</smiles>

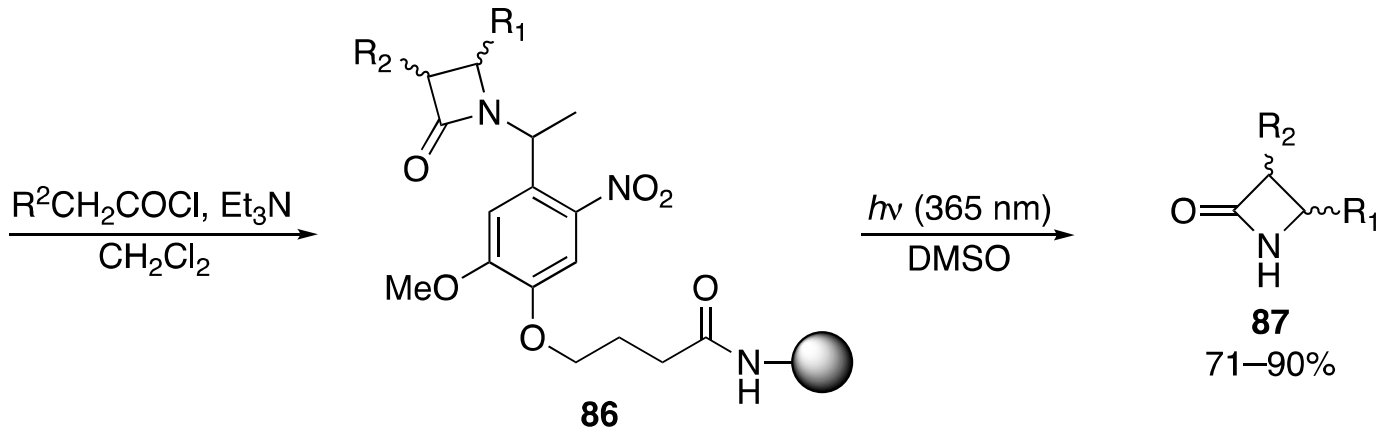

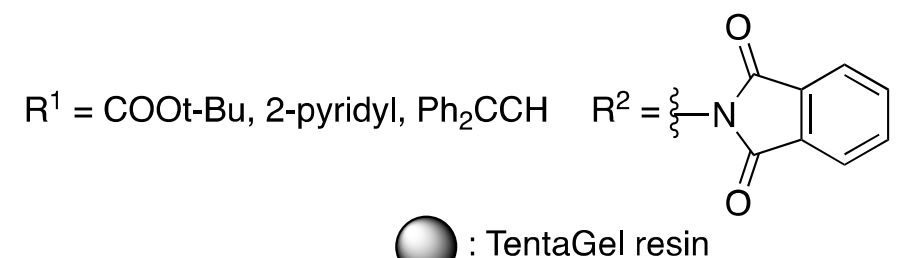

Scheme 19. $\alpha$-Methylated nitroveratryl linker used in the synthesis of $\beta$-lactams.

Minkwitz and Meldal used the aldehyde linker 88, related to $\mathbf{7 4}$, for the synthesis of a small library of arylpiperazine melanocortin subtype-4 agonists.[61] The linker $\mathbf{8 8}$ was synthesized and 
attached to the solid support (Scheme 20). Construct 89 was then subjected to reductive amination and subsequent acylation of the formed amine afforded 91. Finally, two alkylation steps and photolytic cleavage provided arylpiperazines 94.

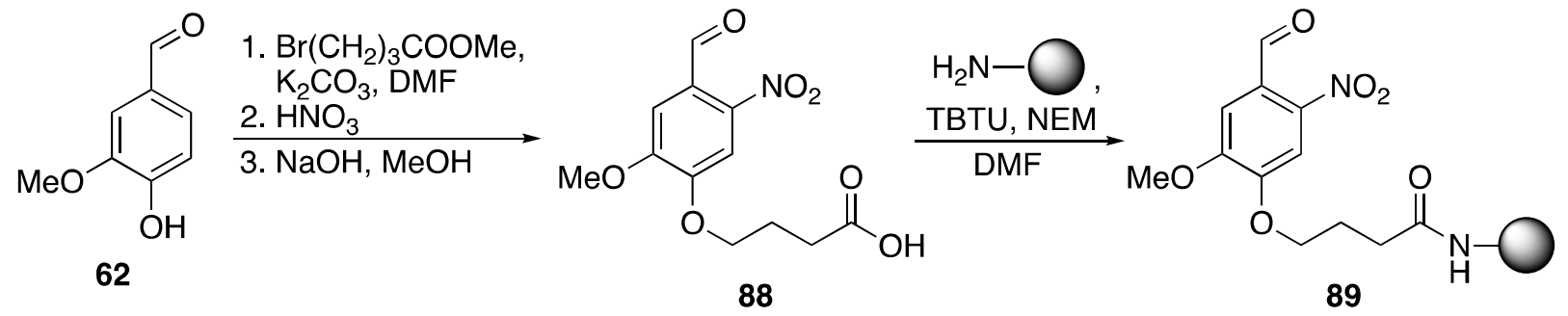<smiles>[R]NCc1cc(OC)c(OCCCC(=O)Nc2ccccc2)cc1[N+](=O)[O-]</smiles>
90

91<smiles>COc1cc(CNC(=O)CN2CCNCC2)c([N+](=O)[O-])cc1OCCCC(=O)Nc1ccccc1</smiles><smiles>[R16][R9]</smiles>

O: PEGA $_{800}$

Scheme 20. Photolabile linker used for the synthesis of melanocortin subtype-4 agonists.

Qvortrup and Nielsen introduced an azido-functionalized linker based on the $o$-nitroveratryl group for the synthesis of 1,2,3-trizoles,[62] cf. Scheme 21. 
<smiles>CCOC(=O)CCCOc1cc([N+](=O)[O-])c(C(C)O)cc1OC</smiles><smiles>CCOC(=O)CCCOc1cc([N+](=O)[O-])c(OC)cc1C(C)Cl</smiles><smiles>COc1cc(C(C)N)c([N+](=O)[O-])cc1OCCCC(=O)O</smiles>

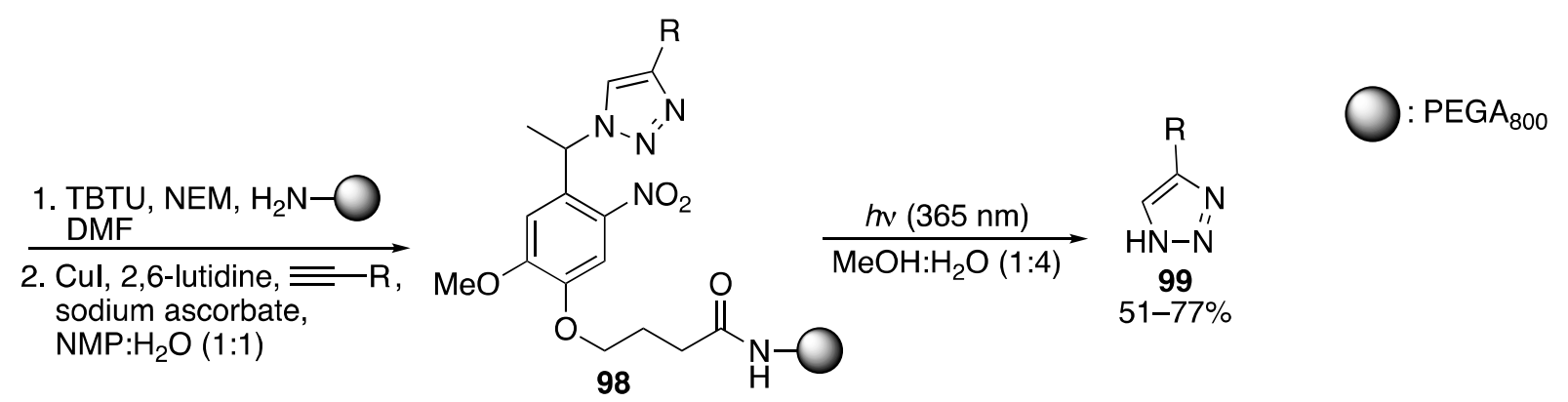

Scheme 21. Photolabile nitroveratryl-based azido-linker used for the synthesis of 1,2,3-triazoles.

The alcohol 95 was synthesized through procedures adapted from Holmes and co-workers (Scheme 17). The alcohol was then subjected to $\mathrm{SOCl}_{2}$ and after substitution with $\mathrm{NaN}_{3}$ and ester hydrolysis with $\mathrm{LiOH}$, the azido linker 97 was obtained. Attachment to the solid support and subsequent copper(I)-catalyzed azide-alkyne cycloaddition led to the construct 98, which after photolytic cleavage provided 1,2,3-triazoles 99 in good yields. Nielsen and coworkers later introduced a hydrazine linker.[63] Starting from chloride 96, the linker $\mathbf{1 0 0}$ was synthesized in two steps, and following attachment to the solid support, SPPS and photolytic cleavage provided peptide hydrazides 103 in yields of $21-83 \%$ (Scheme 22 ). 


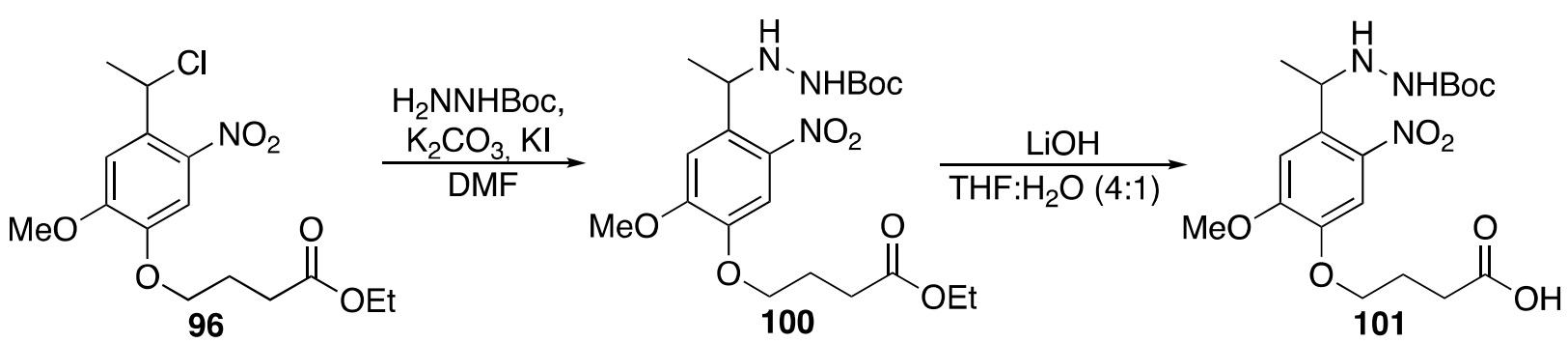<smiles>COc1cc(C(C)NN)c([N+](=O)[O-])cc1OCCC(=O)NOCC(=O)ONC(=O)ON</smiles>
1. TBTU, NEM, $\mathrm{H}_{2} \mathrm{~N}-\mathrm{O}$
$\stackrel{\text { DMF }}{\text { 2. TMSOTf, 2,6-lutidine, }}$
$\mathrm{CH}_{2} \mathrm{Cl}_{2}$

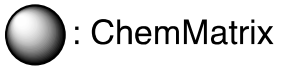

Scheme 22. Photolabile nitroveratryl-based linker used for the synthesis of peptide hydrazides.

The construct $\mathbf{1 0 1}$ could also be utilized for the solid-phase synthesis of dihydropyrano[2,3c]pyrazoles.[63]

Recently, Qvortrup et al. introduced a photolabile nitroveratryl-based linker $\mathbf{1 0 4}$ for the synthesis and release of hydroxamic acids.[64, 65] Furthermore, they showed, that this linker unit may, uniquely, function as a 'bidetachable' system.[64] By simply varying the reaction solvent, the photolysis could be controlled to provide either $\mathrm{C}-\mathrm{O}$ or $\mathrm{C}-\mathrm{N}$ bond cleavage, which allowed for controlled release of the hydroxamates 106 or carboxamides 105 , respectively (Scheme 23).

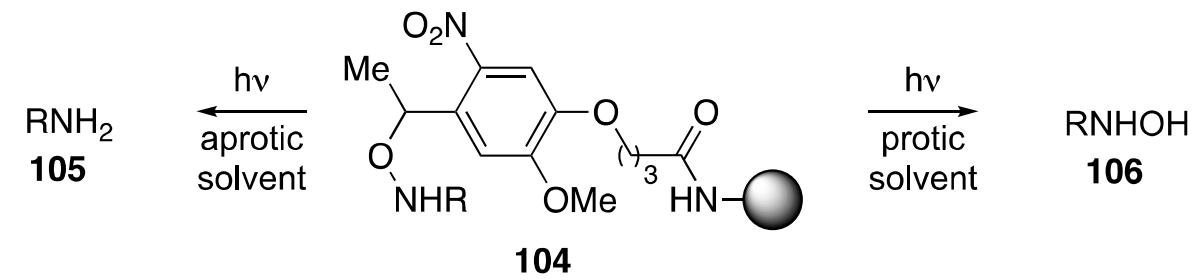

Scheme 23. Bi-detachable linker: Solvent-controlled chemoselectivity of phololysis to provide the hydroxamate or carboxamide, respectively. 
Another recent example is the linker developed by Lee and co-workers.[66] This linker is tethered to the solid support through the $\alpha$-position. Starting from veratraldehyde (107) the linker 112 was synthesized in six steps (Scheme 24).
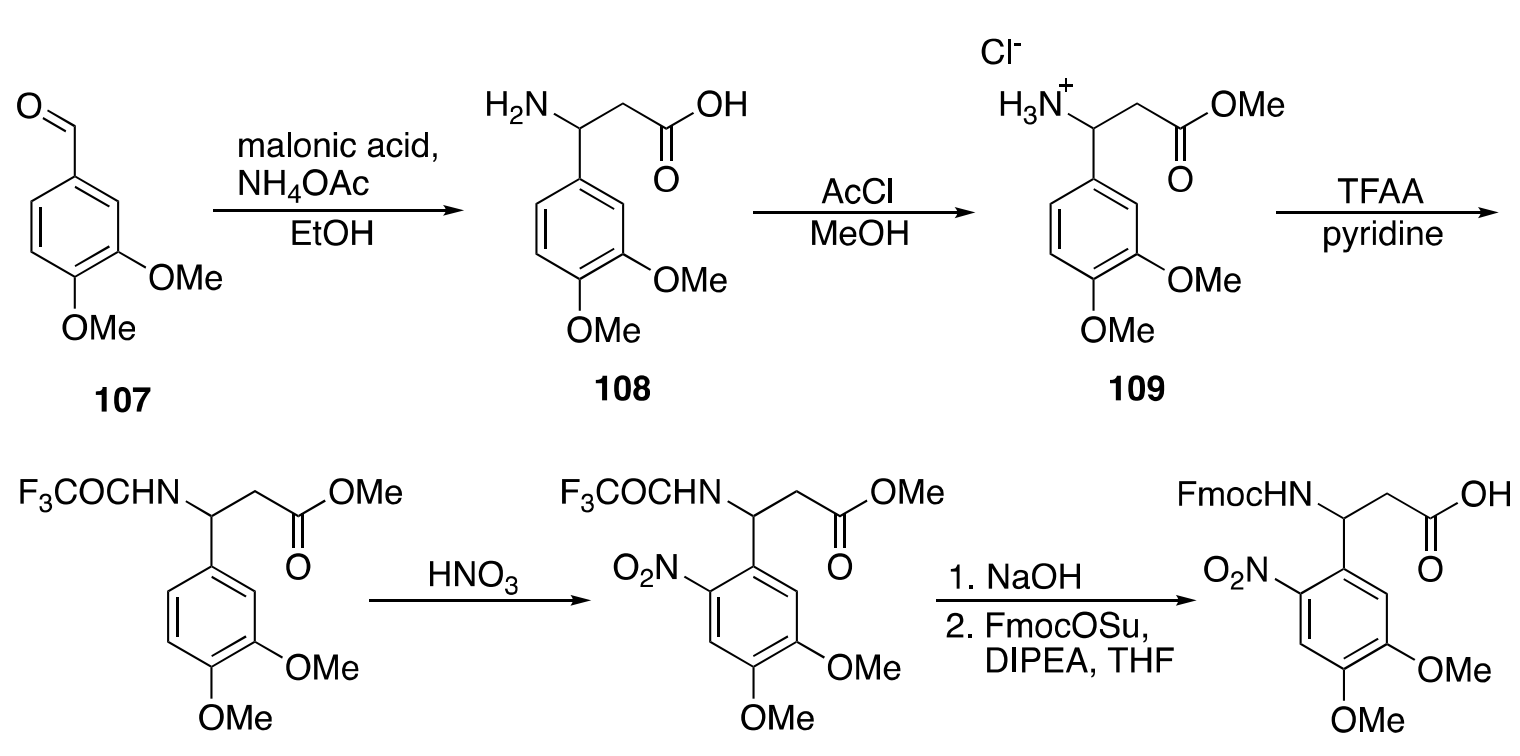
110 111 112 1. $\mathrm{H}_{2} \mathrm{~N}-\mathrm{O}, \mathrm{BOP}, \mathrm{HOBt}$, \begin{tabular}{lc} 
DIPEA, DMF & H-Tyr-Gly-Gly-Phe-Leu-NH \\
\hline 2. SPPS & 113 \\
3. $h v(365 \mathrm{~nm}), \mathrm{MeOH}$ & $50 \%$
\end{tabular} : HiCore resin

Scheme 24. Synthesis of Leu-enkephalin amide using photolabilie linker 112.

After coupling to the solid support, standard SPPS and photolytic cleavage provided Leuenkephaline amide (113) in a yield of 50\%.

\section{Phenacyl linkers}

Another useful photo-cleavable linker is based on the phenacyl $\left[\mathrm{PhC}(\mathrm{O}) \mathrm{CH}_{2}-\right]$ group. The aryl carbonyl undergoes $n \rightarrow \pi^{*}$ or $\pi \rightarrow \pi^{*}$ excitation upon UV radiation (300-350 nm), followed by hydrogen atom abstraction from solvent and bond scission to cleave the linker (Figure 3).[67] 


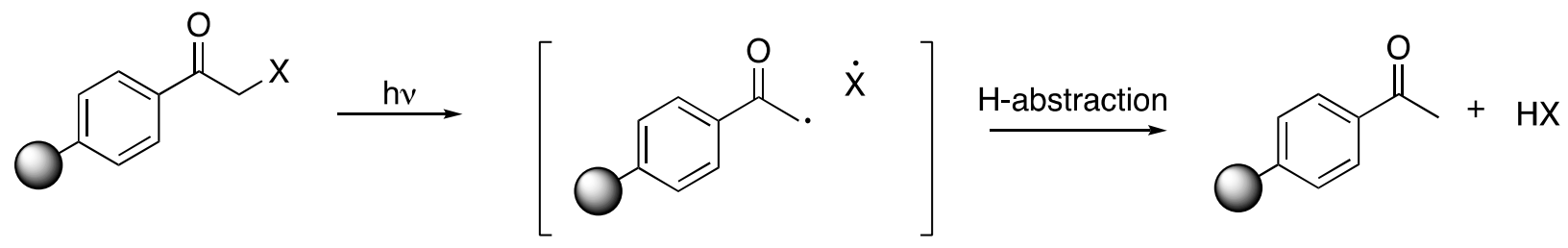

Figure 3. Photochemistry of aromatic ketones that release a leaving group (X).

The phenacyl group was explored in pioneering studies on photolabile linkers by Wang.[68] The resin 1 was subjected to Friedel-Crafts acylation with 2-bromopropionyl chloride, and the first amino acid was $O$-alkylated to provide construct 115, cf. Scheme 25. Subsequent standard SPPS and final photolysis released the peptide 117 in $70 \%$ yield.

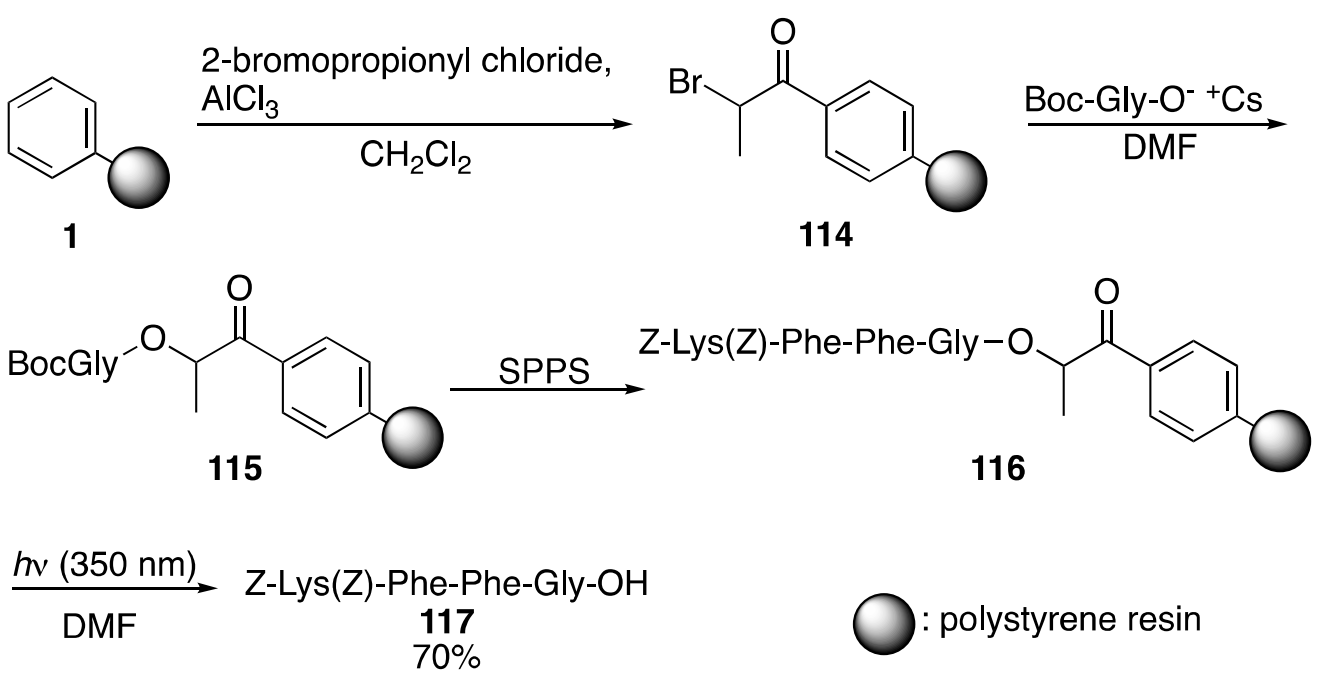

Scheme 25. Synthesis of a phenacyl photolabile handle and its use in peptide synthesis.

A phenacyl linker was also used by Tam to produce resins cleavable under both photolytic, basic or nucleophilic conditions.[12, 13]

Tjoeng and Heavner developed a non-integral phenacyl linker system,[69] which was synthesized in solution and coupled to the resin, to avoid the direct derivatization of the resin as described by Wang. Initial esterification of phenylacetic acid (118) and subsequent Friedel- 
Crafts acylation led to the methyl ester 119, which upon simple ester hydrolysis led to the phenacyl linker 120 (Scheme 26). With 120 in hand, attachment to the resin and coupling of the first amino acid, followed by standard SPPS led to the peptide $\mathbf{1 2 4}$ in $78 \%$ yield after photolytic release.[68]<smiles>O=C(O)Cc1ccccc1</smiles>

$\underline{\mathrm{HCl}: \mathrm{H}_{2} \mathrm{O} \text { :acetone (15:35:50) }}$

1. $\mathrm{MeOH}, \mathrm{H}_{2} \mathrm{SO}_{4}$

2. 2-bromopropionyl chloride,

$\mathrm{AlCl}_{3}, \mathrm{Cl}_{2} \mathrm{CHCHCl}_{2}$<smiles>C=C(c1ccc(CC(=O)O)cc1)C(C)Br</smiles>
121

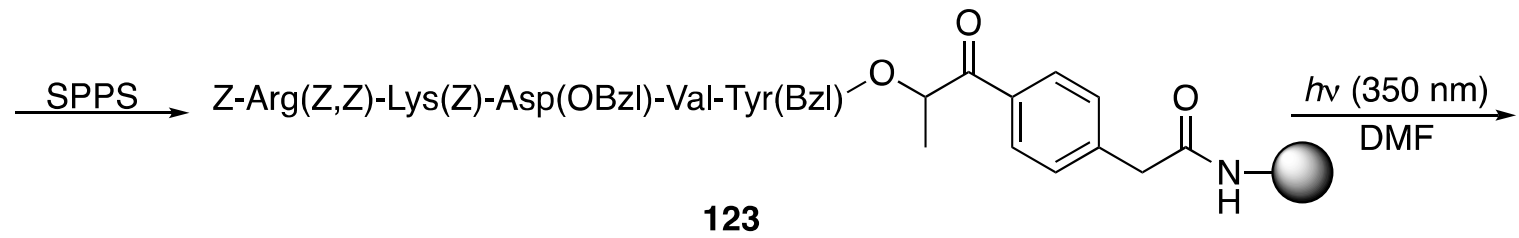

Z-Arg(Z,Z)-Lys(Z)-Asp(OBzl)-Val-Tyr(Bzl)-OH 124
$78 \%$<smiles>COC(=O)Cc1ccc(C(=O)C(C)Br)cc1</smiles>

119 
shortening the irradiation times. The synthesis started from methyl phenoxyacetate (125), which after Friedel-Crafts acylation and ester hydrolysis provided the bromide 126 (Scheme 27). Coupling to the resin followed by attachment of the first amino acid, either in the presence of KF or as its cesium salt, led to 128. Conventional SPPS, photolysis and deprotection led to the peptide 129 in $71 \%$ yield.<smiles>CC(Br)C(=O)c1ccc(OCC(=O)OCCOCCOCC(=O)OCC(=O)Oc2ccccc2)cc1</smiles><smiles>CCCCOc1ccc(C(=O)C(C)Br)cc1</smiles>

1. SPPS

2. $h v(350 \mathrm{~nm}), \mathrm{DMF}$

3. deprotection

H-Tyr-Gly-Gly-Phe-Leu-OH

129

$71 \%$

: aminomethyl polystyrene resin

Scheme 27. Synthesis of a $p$-alkoxyphenacyl photolabile linker for peptide synthesis.

Gauthier and co-workers used the same linker for the synthesis of octapeptides in good yield $(>85 \%)$, as illustrated by the efficient synthesis of mammalian glucagon.[71] Belshaw and coworkers developed a safety-catch photolabile linker based on the p-alkoxyphenacyl moiety.[72] The photolability of the linker was masked to enable the use of photolabile protecting groups in light-directed synthesis of oligonucleotides. The linker synthesis started from acetophenone 130, (Scheme 28). A Mitsunobu reaction led to 131, which after acetal formation and methyl oxidation provided the alcohol 132. Protection with the photolabile NPPOC group followed by alcohol deprotection gave 133, which was then prepared for attachment to the solid support by treatment with 2-cyanoethyl diisopropylchlorophosporamidite resulting in the linker 134. Linker 
134 was attached to the solid support and iterative cycles of photolytic deprotection and coupling of nucleotides bearing a photocleavable protecting group furnished construct 136. Mild acidic hydrolysis then activated the linker for photolytic cleavage and final photolysis provided the DNA chain 138.

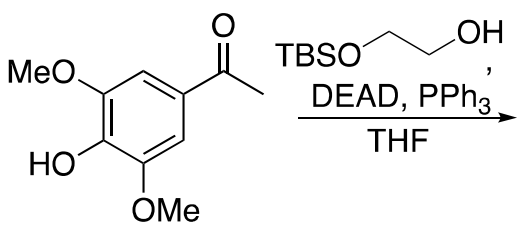

130

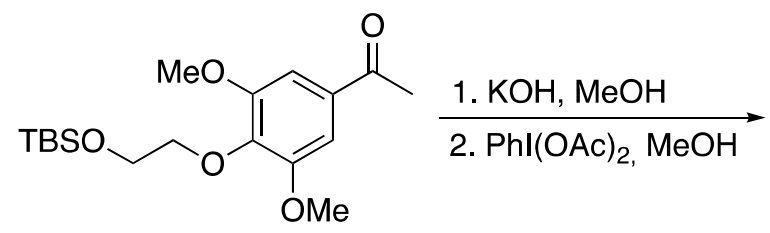

131<smiles></smiles>

132 133

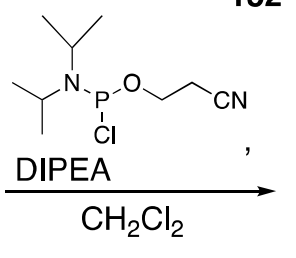<smiles>[CH2]CC(OC)(OC(=O)OCC(C)c1ccccc1[N+](=O)[O-])c1cc(OC)c(OCCOP(C)OCCC#N)c(OC)c1</smiles>

134<smiles>COc1cc(C(COC(=O)OCC(C)c2ccccc2[N+](=O)[O-])(OC)OC)cc(OC)c1OC</smiles>

135

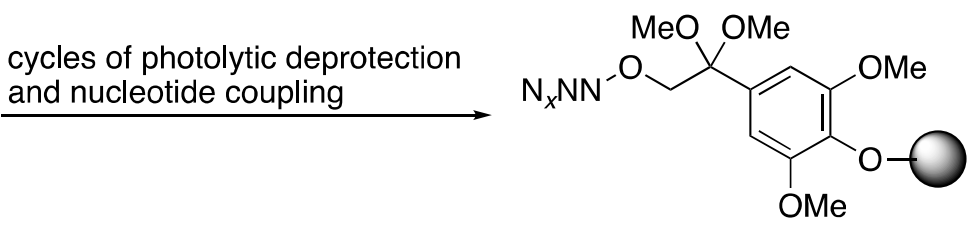

136<smiles>COc1cc(C(=O)CON=N)cc(OC)c1OCN(C)N=[W]</smiles>

: monohydroxy glass slide

Scheme 28. Synthesis and use of a safety-catch photolabile linker for light directed synthesis and release of oligonucleotides $\left(\mathrm{NNN}_{x}=\right.$ DNA chain $)$. 
Sucholeiki introduced a traceless thioether $p$-methoxyphenacyl linker for use in Stille crosscouplings.[73, 74] Methylation of 139, Friedel-Crafts acylation and halogen exchange led to the chloride 142 (Scheme 29).
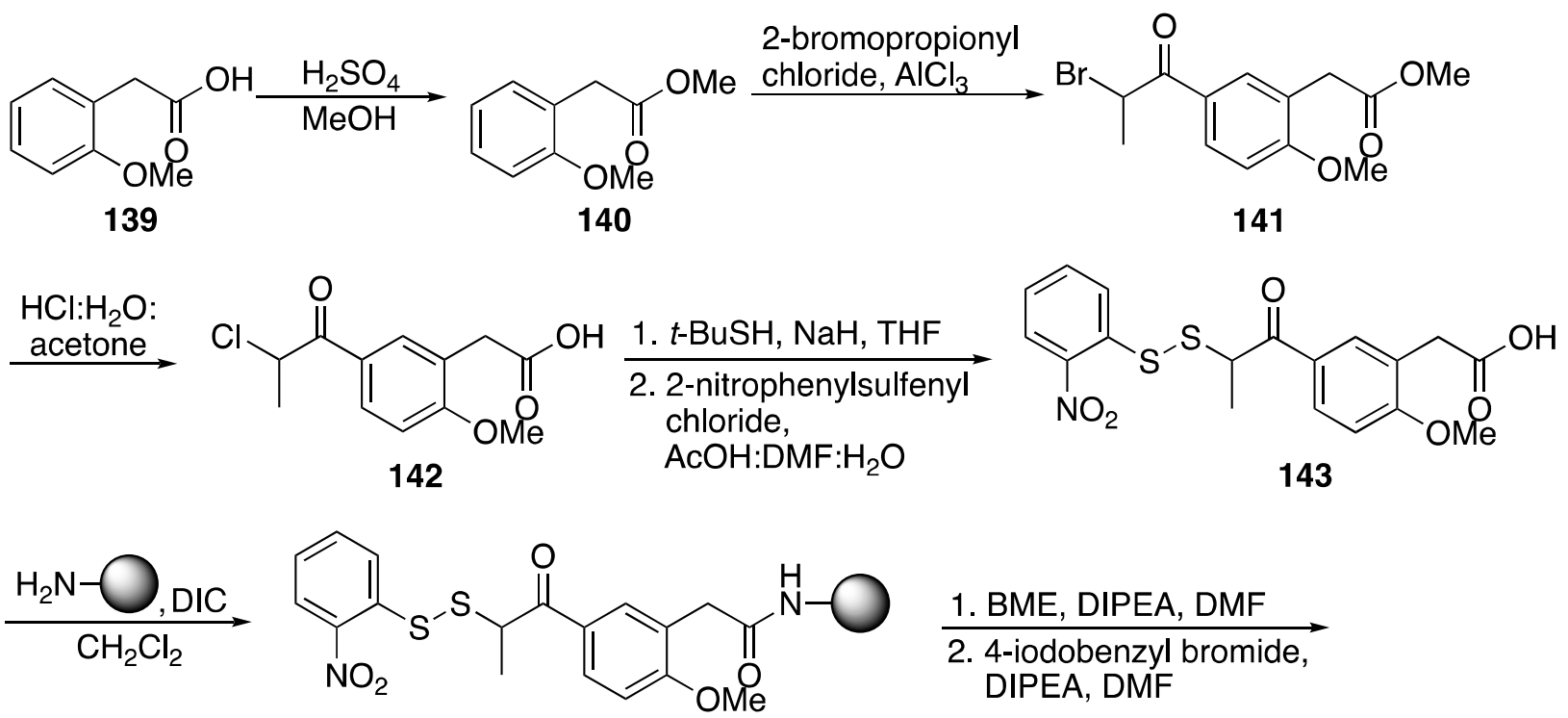

144
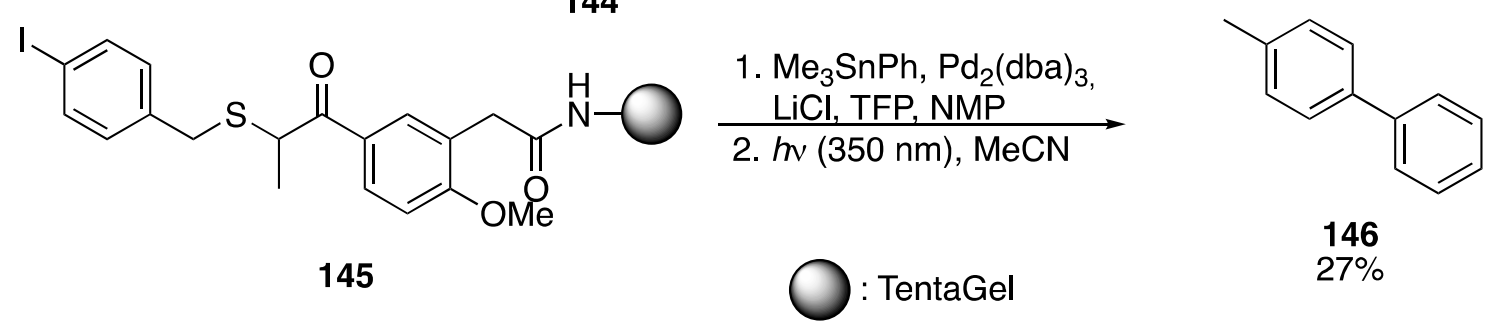

Scheme 29. Synthesis and use of a traceless thioether $p$-methoxyphenacyl linker in Stille crosscoupling reactions.

Substitution and disulfide formation then furnished the linker 143, which after attachment to the solid support and disulfide cleavage was reacted with 4-iodobenzyl bromide to provide construct 145. Pd-catalyzed Stille cross-coupling and subsequent photolysis led to the biaryl 146 in a yield of $27 \%$.

\section{Benzoin linkers}


The photolysis of $3^{\prime}, 5^{\prime}$-dialkoxybenzoin can be rationalized as a diradical process starting from an $\mathrm{n} \rightarrow \pi *$ transition. A charge transfer interaction of the electron-rich dialkoxyphenyl moiety with the electron deficient oxygen of an $\mathrm{n} \rightarrow \pi *$ singlet excited ketone form an intramolecular exciplex, which after rearrangement, leads to release of the product and formation of the benzofuran (Figure 4).<smiles>[R]C(=O)OC(C(=O)c1ccccc1)C(OC([R])=O)c1cc(OC)cc(OO)c1</smiles><smiles>[R]C(=O)OC1C(c2ccccc2)OC2(O)C(OC)=CC(OOC)=CC12</smiles>

Figure 4. Photoinduced cleavage of a Benzoin linker.

Rock and Chan developed a benzoin safety-catch linker for the purpose of binding two molecules together in solution.[75] This was later exploited for solid-phase synthesis by Balasubramanian and co-workers.[76, 77] The synthesis started from 3-hydroxybenzaldehyde (147) which was coupled to the resin and reacted with 2-phenyl-1,3-dithiane to form a dithioacetal, which effectively functioned as a safety-catch moiety that can be triggered upon hydrolysis (Scheme 30). Fmoc- $\beta$-Ala-OH was then coupled to the resin to give 150, which upon hydrolysis of the dithioacetal and photolysis released the amino acid 152 in excellent yields. Good to excellent yields (75-97\%) were obtained using this strategy with other carboxylic acids. 


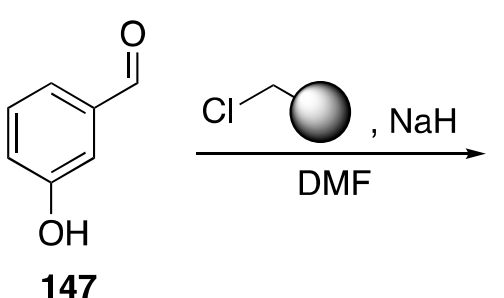<smiles>O=Cc1cccc(OCc2ccccc2)c1</smiles><smiles>CC(C)C1SCCCS1</smiles>

148<smiles>OC(c1cccc(OCc2ccccc2)c1)C1(P)SCCCS1</smiles>

149
Fmoc- $\beta$-Ala-OH, DIC,
DIPEA, HOBt, DMAP
$\stackrel{\text { DMF }}{\longrightarrow}$<smiles>O=C(CCNC(=O)OC(c1cccc(OCc2ccccc2)c1)C1(P)SCCCS1)Oc1ccccc1</smiles>

150

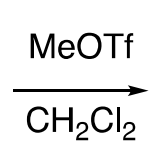<smiles>O=C(CCNCc1ccccc1)OC(C(=O)c1ccccc1)c1cccc(OCc2ccccc2)c1</smiles>

151
: Merrifield resin

Scheme 30. Use of photolabile benzoin safety-catch linker in solid-phase synthesis.

Later Balasubramanian and co-workers developed a second-generation, non-integral benzoin linker.[78] The linker was prepared with a carboxylic acid as anchoring point to exploit the wide range of amine functionalized resins available, notably with a long tether, as this had previously been shown to be advantageous for $o$-nitroveratryl linkers. The synthesis started from aldehyde 153 and a six-step sequence led to the linker 158, cf. Scheme 31. 


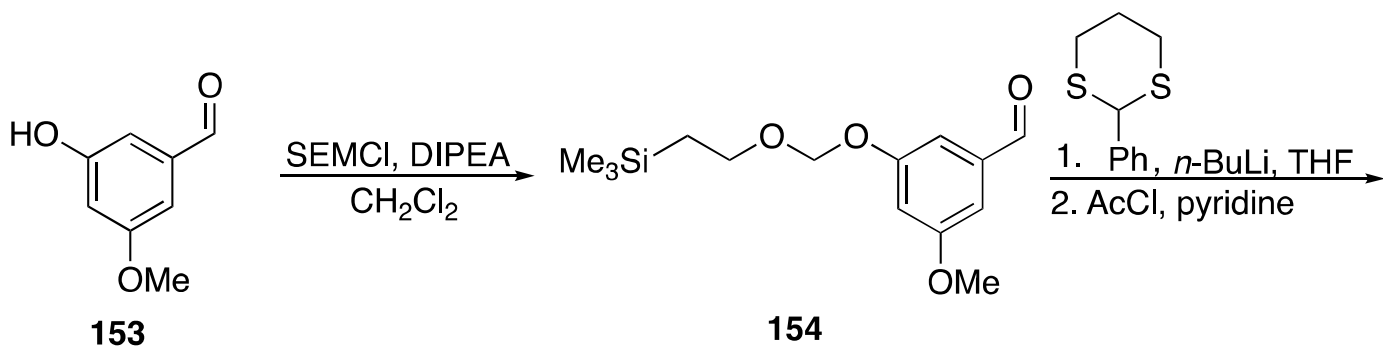

154<smiles>COc1cc(O)cc(C(OC(C)=O)C2(c3ccccc3)SCCCS2(c2ccccc2)C(OC(C)=O)c2cc(OC)cc(OCOCC[SiH3])c2)c1</smiles>

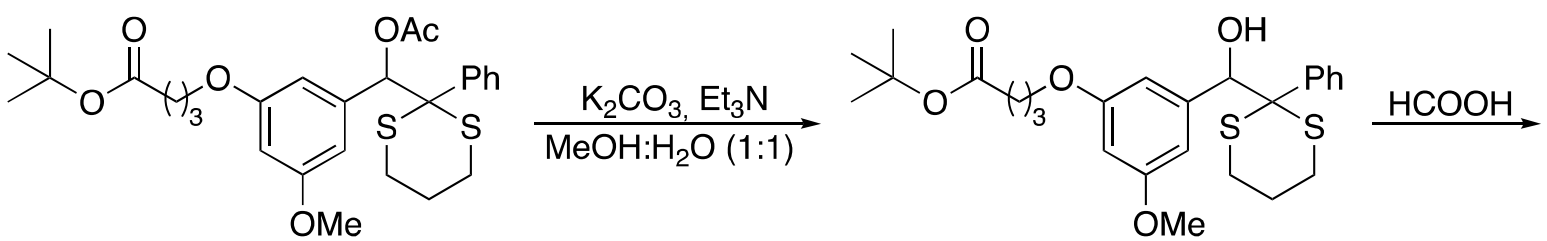

156

157<smiles>COc1cc(O[As]C(=O)O)cc(C(O)C2(c3ccccc3)SCCCS2)c1</smiles>

158

Scheme 31. Synthesis of a photolabile benzoin linker with a carboxylic acid anchor.

To address the often challenging dithioacetal removal, Copley and coworkers developed a new benzoin linker in which the carbonyl group was protected as a dimethyl ketal.[79] The dimethyl ketal moiety is stable towards common solid-phase esterification and amide bond formation reaction conditions, yet easily removable with 3\% TFA. The synthesis of the linker started from 3-formylbenzoic acid (159), followed by a four-step sequence to provide dithioacetal 163 (Scheme 32). Finally, the dithioacetal functionality was replaced with a dimethyl ketal to provide linker 164. Attachment to the solid support, subsequent SPPS and photolysis released the tetradecapeptide $\mathbf{1 6 5}$. 
<smiles>CCO[R16](=O)C[C@H]1SCCC[SH]1c1cccc(C(=O)O)c1</smiles>

159

160<smiles>COc1cc(OC)cc(C(O)C2(c3cccc(C(=O)O)c3)SCCCS2)c1</smiles>

161

162<smiles>COc1cc(OC)cc(C([O-])C(OC)(OC)C([O-])(OC)c2cc(OC)cc(OC)c2)c1</smiles>

163

164

1. $\mathrm{H}_{2} \mathrm{~N} \longrightarrow$, PyAOP, HOAt,

DIPEA, DMF

2. SPPS

3. $h v, \mathrm{MeOH}: \mathrm{H}_{2} \mathrm{O}(3: 7)$

H-Lys-Tyr-Arg-Arg-Arg-Pro-Arg-Arg-Ser-GIn-Arg-Lys-Arg-Gly-OH 165

: TentaGel resin BTI: [bis(trifluoroacetoxy)iodo]benzene

Scheme 32. Synthesis and use of a photolabile dimethyl ketal benzoin linker for peptide synthesis.

\section{Pivaloyl linkers}

Pivaloyl derivatives fragment by a Norrish type I mechanism, releasing carboxylic acids or alcohols (Figure 5). The side-products, carbon monoxide and isobutene, are all volatile, making purification simple. However, the process requires the use of a relatively short wavelength source (280-340 nm), which may cause side reactions when applied to more fragile biomolecules. 


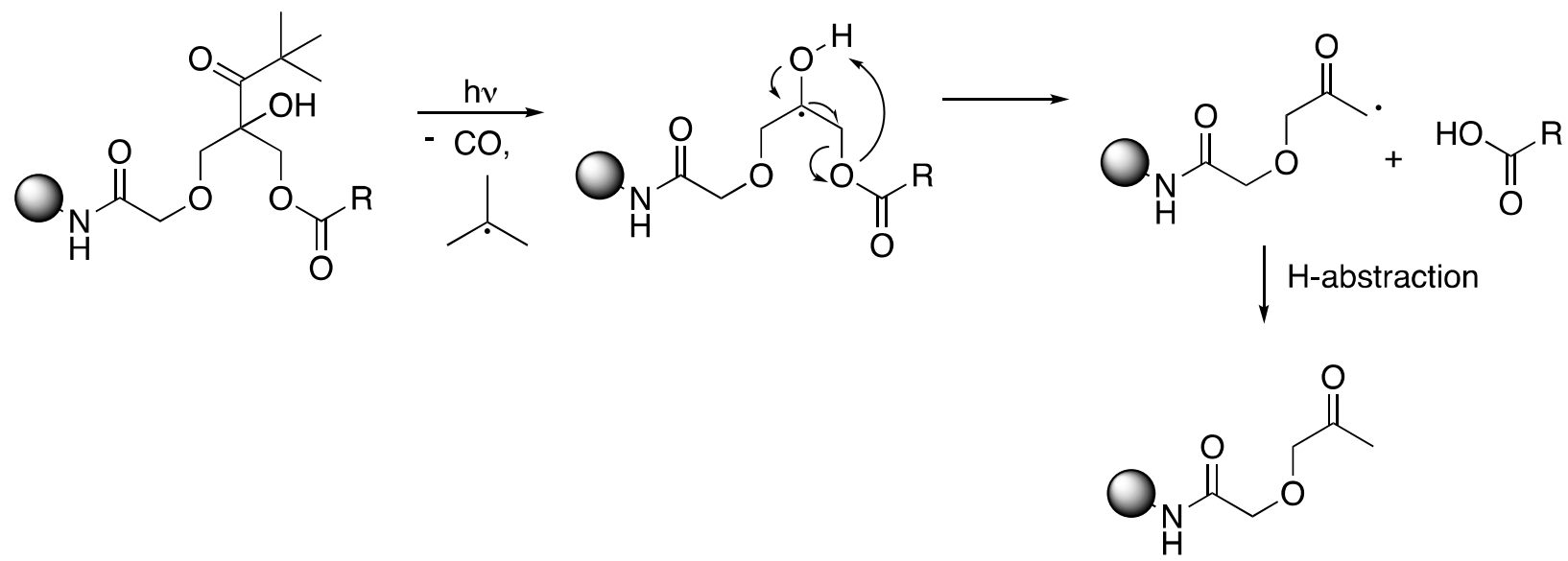

Figure 5. Photolysis of a pivaloyl-based linker.

Peukert and Giese developed a photolabile linker based on the pivaloyl group.[80] The synthesis started from 1,3-dihydroxyacetone dimer (166) and a six-step sequence gave the linker 171 in an overall yield of $40 \%$ (Scheme 32). The linker was then coupled to the solid support and following attachment of the first amino acid, standard SPPS provided construct 174, which upon photolysis released the peptide $\mathbf{1 7 5}$ in a yield of $86 \%$. 


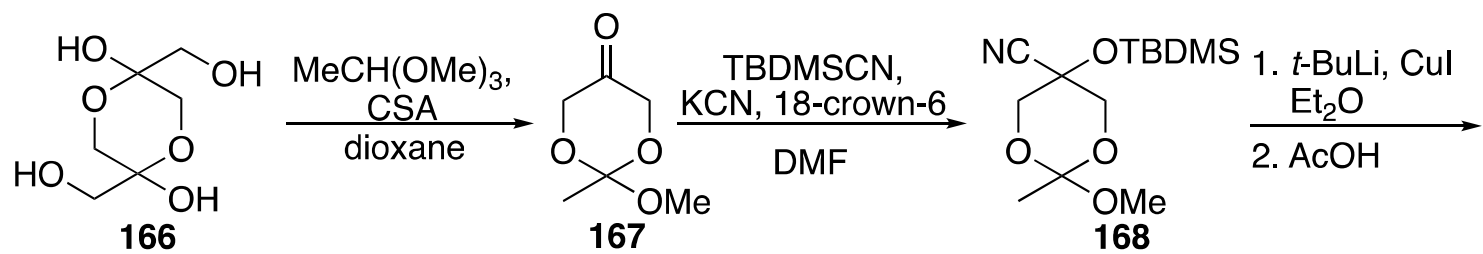

\section{1. $\mathrm{DIC}, \mathrm{H}_{2} \mathrm{~N}-\mathrm{O}$}

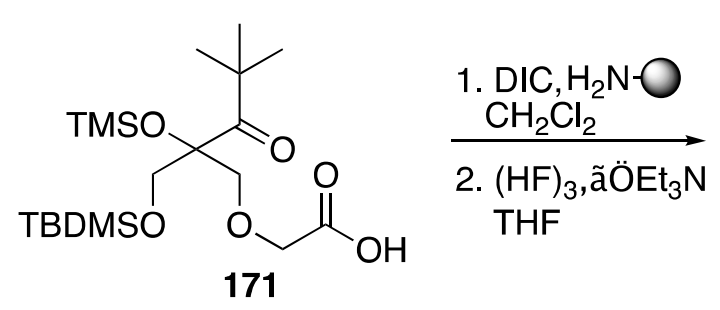

2. $(\mathrm{HF})_{3}, \tilde{a} O ̈ E t_{3} \mathrm{~N}$ THF

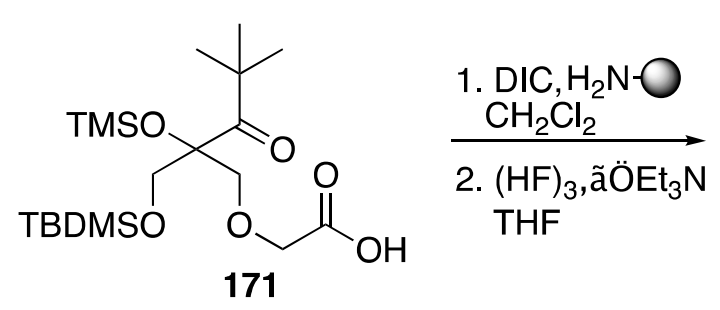
171 $\frac{\text { 1. } \mathrm{K}_{2} \mathrm{CO}_{3}, \mathrm{MeOH}}{\text { 2. } \mathrm{BrCH}_{2} \mathrm{COOt}-\mathrm{Bu}, \mathrm{Ag}_{2} \mathrm{O},}$<smiles>CC(C)(C)OCC(O)(COCC(=O)OC(C)(C)C)C(=O)C(C)(C)C</smiles>

170
TMSOTf, $\underline{\text { 2,6-lutidine }}$

THF<smiles>CC(C)(C)C(=O)C(O)(CO)COCC(=O)Nc1ccccc1</smiles>

Fmoc-Leu-anhydride, DMAP

DMF

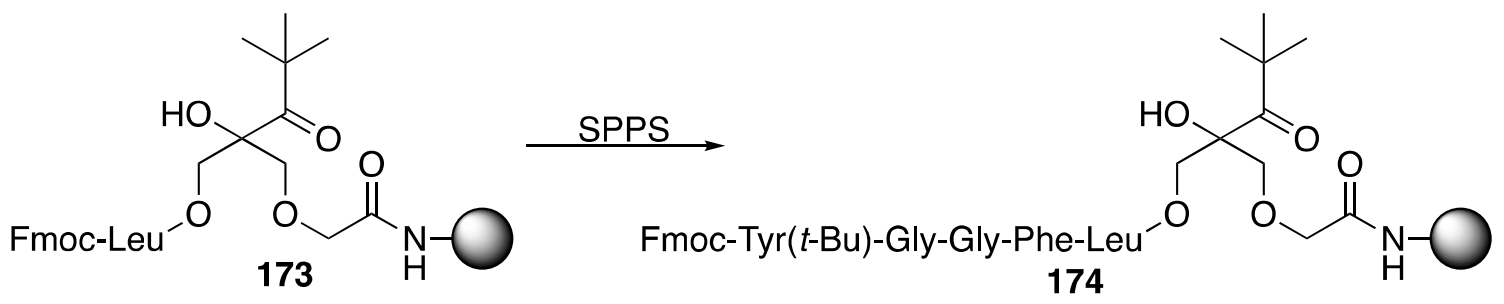

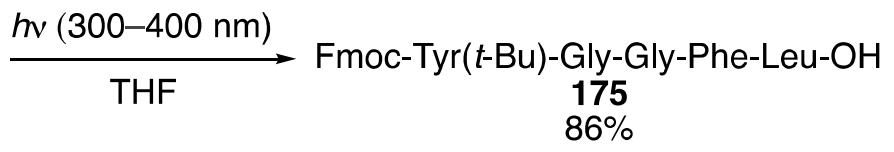

: TentaGel resin

Scheme 33. Synthesis and use of a pivaloyl-based photolabile linker.

The linker $\mathbf{1 7 1}$ also proved useful for the generation and release of compounds relying on Pdcatalyzed Stille and Suzuki cross-coupling, and epoxidation reactions.[80] Later, a modified linker enabled the release of alcohols upon photolysis.[81]

Bochet and coworkers exploited the property of the pivaloyl linker, used in the synthesis of LeuEnkephalin, as being stable at longer wavelengths, thus enabling the use of photolabile protection groups with different chromatic lability.[82] The synthesis started with the coupling 
of NVOC-Leu-OH to the linker resin $\mathbf{1 7 6}$ under standard conditions (Scheme 34). Four cycles of photolytic deprotection $(360 \mathrm{~nm})$ and amino acid coupling reactions furnished construct 178. Finally deprotection and photolytic cleavage from the resin $(305 \mathrm{~nm})$ released Leu-enkephalin 179 in a yield of $55 \%$.

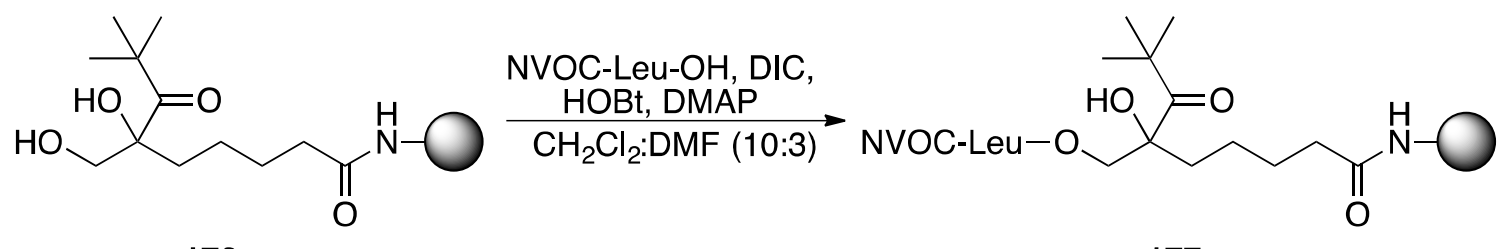

176

177

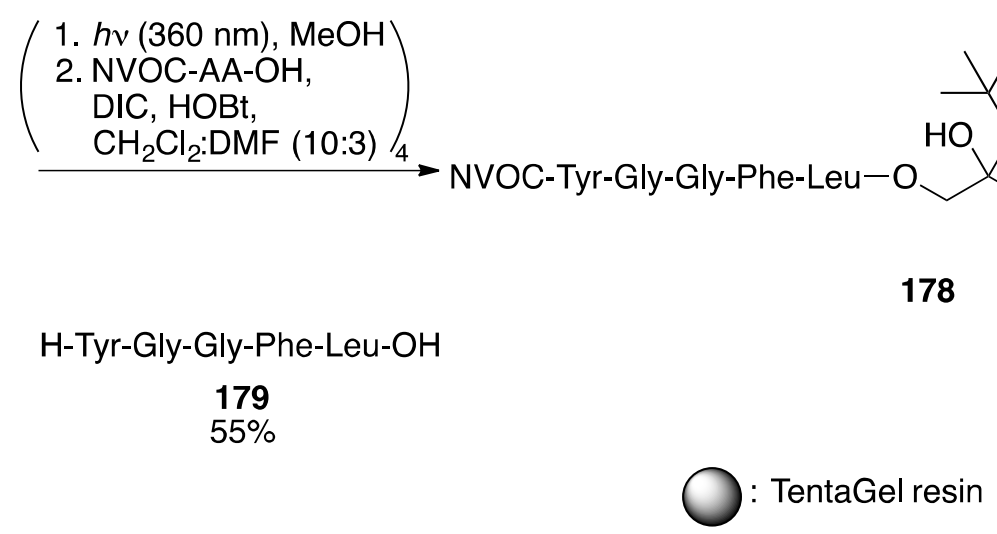

Scheme 34. Synthesis of Leu-Enkephalin utilizing both a photolabile linker and photolabile protecting groups.

\section{Other photolabile linkers}

Routledge and co-workers introduced a traceless photolabile linker based on thiohydroxamic acid.[83] Starting with attachment of trityl-protected 4-hydroxymercaptophenol $\mathbf{1 8 0}$ to the solid support, the linker construct 184 was prepared in four steps (Scheme 35). 


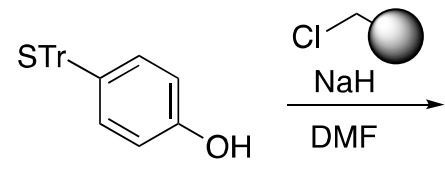

180

181
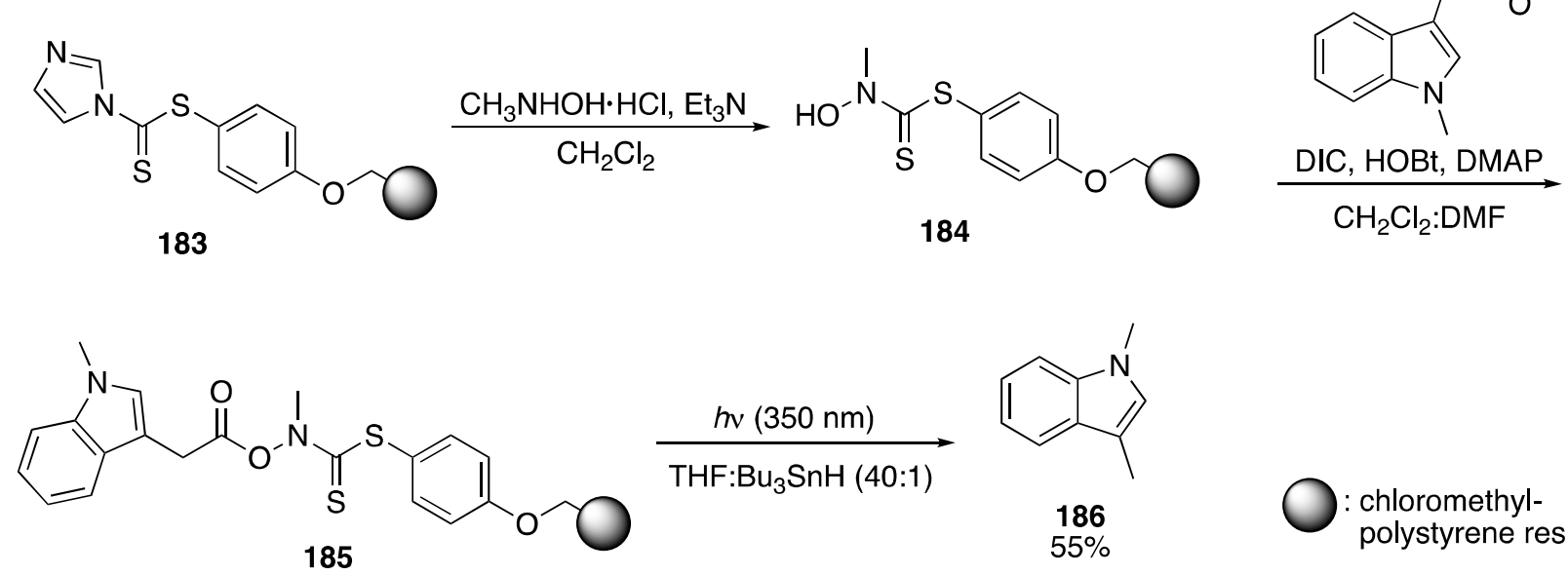

Scheme 35. Synthesis and use of a traceless photolabile linker.

Then $N$-methylindole-3-acetic acid was attached, and photolysis yielded 1,3-dimethylindole 186 in a yield of 55\%. This method, however, suffers from the need of a hydrogen-donor, such as a toxic tin hydride species to facilitate release from the solid support, whereas conventional photolysis normally can be achieved under mild and neutral conditions.

Nicolaou et al. introduced a photolabile linker exploiting the photochemical properties of the 5-bromo-7-nitroindoline group.[84] Photolytic release in the presence of amines provided amides. Intramolecular trapping of an attached amine was also explored in the synthesis of heterocycles. The synthesis started from the indole 187 (Scheme 36). 


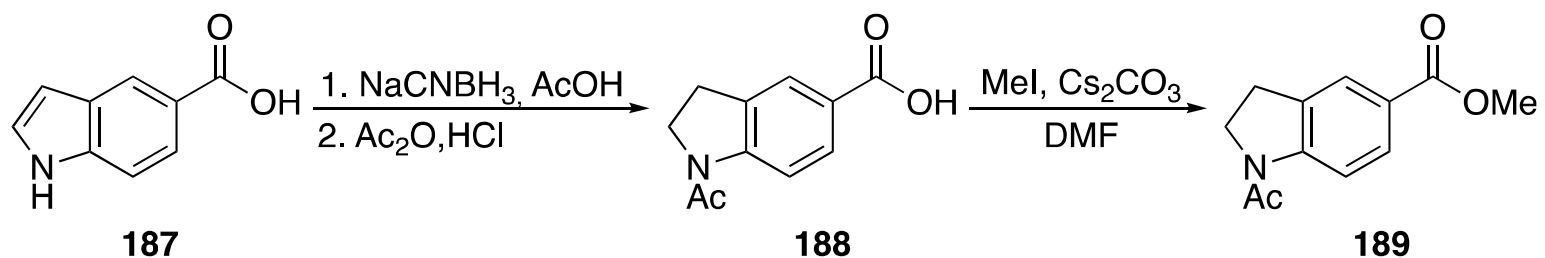

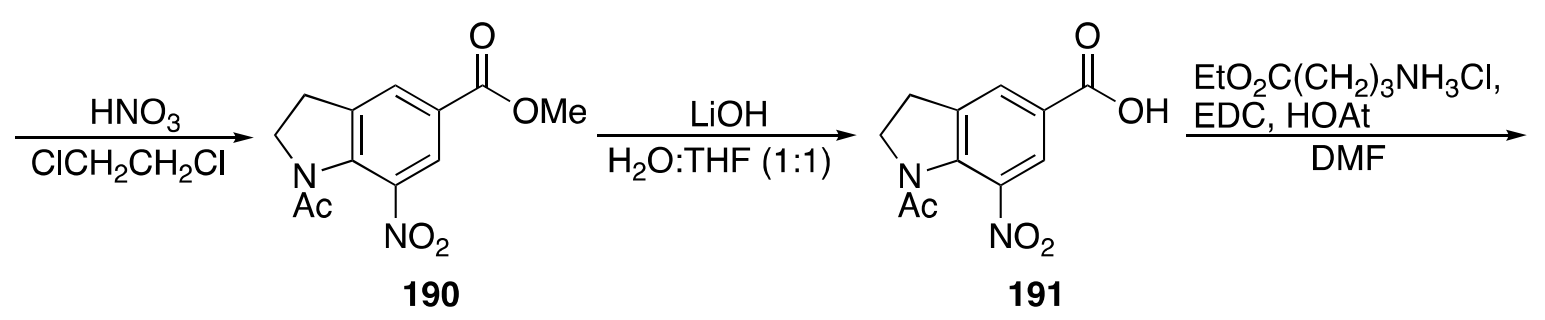<smiles>CCOC(=O)CCCNC(=O)c1cc2c(c([N+](=O)[O-])c1)NC(C[O+])C2</smiles><smiles>CC(C)Oc1ccc(N)cc1</smiles><smiles>CC(C(=O)O)C(=O)Nc1ccc(NC(=O)CCCNC(=O)c2cc3c(c([N+](=O)[O-])c2)NCC3)cc1</smiles>

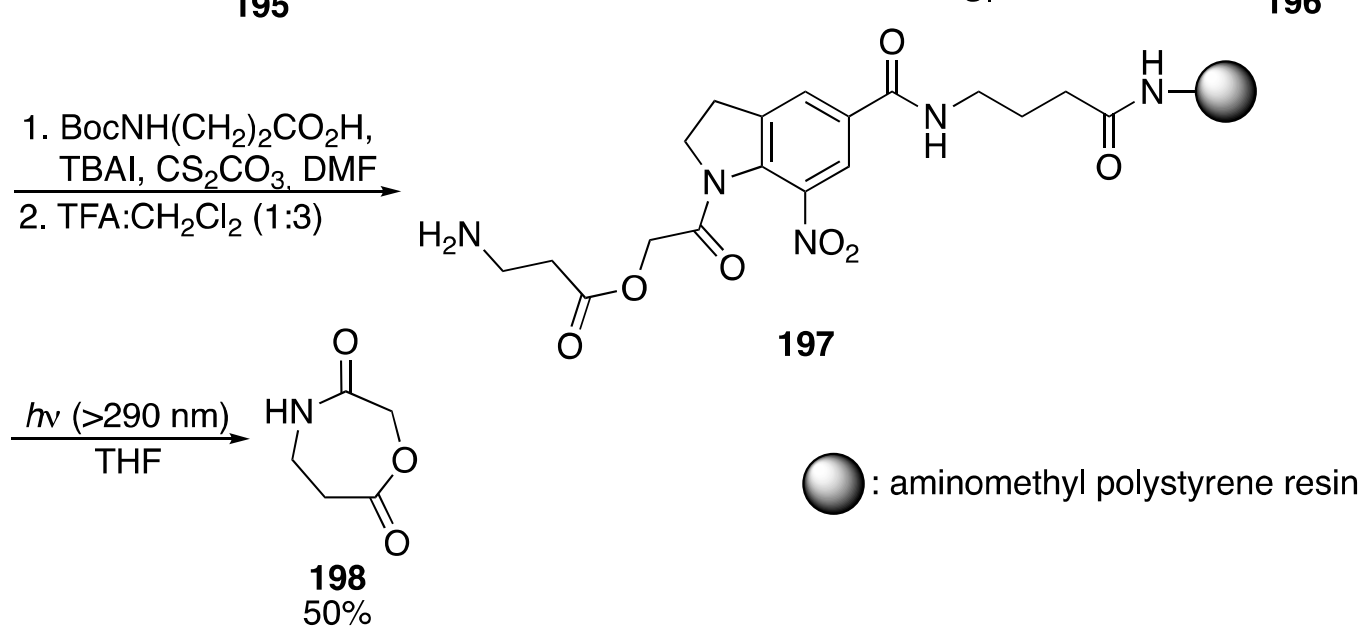

Scheme 36. A photolabile linker for the synthesis of heterocycles. 
Reduction, acylation and methylation led to the methyl ester 189. Nitration followed by ester hydrolysis and amide formation provided the amide 192, which after photolytic removal of the acetyl group and ester hydrolysis furnished the linker 194. Attachment to the solid support and further synthetic elaboration led to the costruct 197, which upon photolytic cyclorelease provided the heterocycle $\mathbf{1 9 8}$ in a yield of 50\%.

A triazene-based photolabile linker was developed by Enders et al.[85] 3-Hydroxyaniline (199) was attached to a Merrifield resin and diazotation followed by reaction with a secondary amine, such as piperazine, led to the triazene construct 202 (Scheme 37).

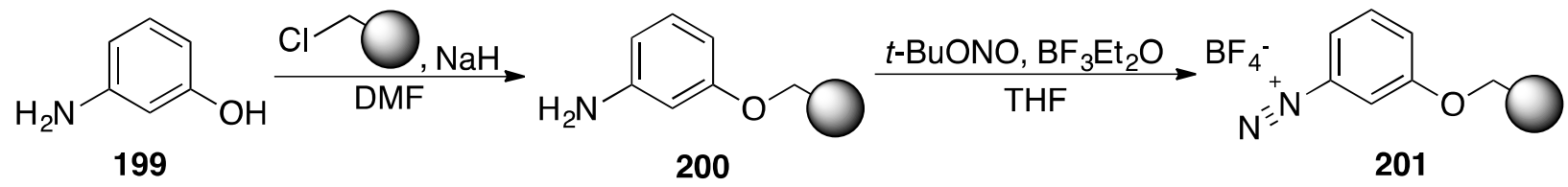<smiles>O=C(C1CCCCC1)C1CCC(C(=O)N2CCN(N=Nc3cccc(OCc4ccccc4)c3)CC2)CC1</smiles>

203<smiles>CCO[C@H](C)[C@H]1CCCC(C(=O)N2CCNCC2)C1</smiles>

: Merrifield resin

Scheme 37. Synthesis and use of triazene-based photolabile linker developed by Enders.

Acylation and photolytic release provided the tertiary amide 204. Generally, moderate yields and excellent purities were achieved.

\section{Perspectives}

As the interest in synthesizing complex molecules, which may be either base- or acid-sensitive, solid support continues to grow, effective protocols for cleavage under mild, neutral conditions remain extremely appealing for SPOS. Fortunately, photolabile linkers provide unique 
opportunities for the release of target molecules under mild, neutral conditions by using UV light. Photochemical cleavage generally proceeds with high functional group selectivity, low amounts of side reactions and involve no post-cleavage purification to separate products from reagents. Furthermore, light-cleavable linkers are stable to most standard chemical conditions used in synthetic transformations and consequently, there is no prematurely cleavage of the library products from the resin beads.

Also, with the development of high-throughput screening techniques, including resin-based bioactivity tests and synthesis of arrays of small molecules on microchips, the importance of photolabile linkers has grown beyond its original purpose. Cleavage can often be performed in aqueous solution, and the liberated products can then be directly employed in biological assays.

The linker of interest may very much depend on the specific application, e.g. some (bio)molecules are not compatible with certain wavelengths and/or specific byproducts. The table below summarizes current photo-cleavable linkers, and the corresponding cleavage conditions. This should prove important for choosing the optimal strategy for a specific application. 
o-Nitrobenzyl linkers

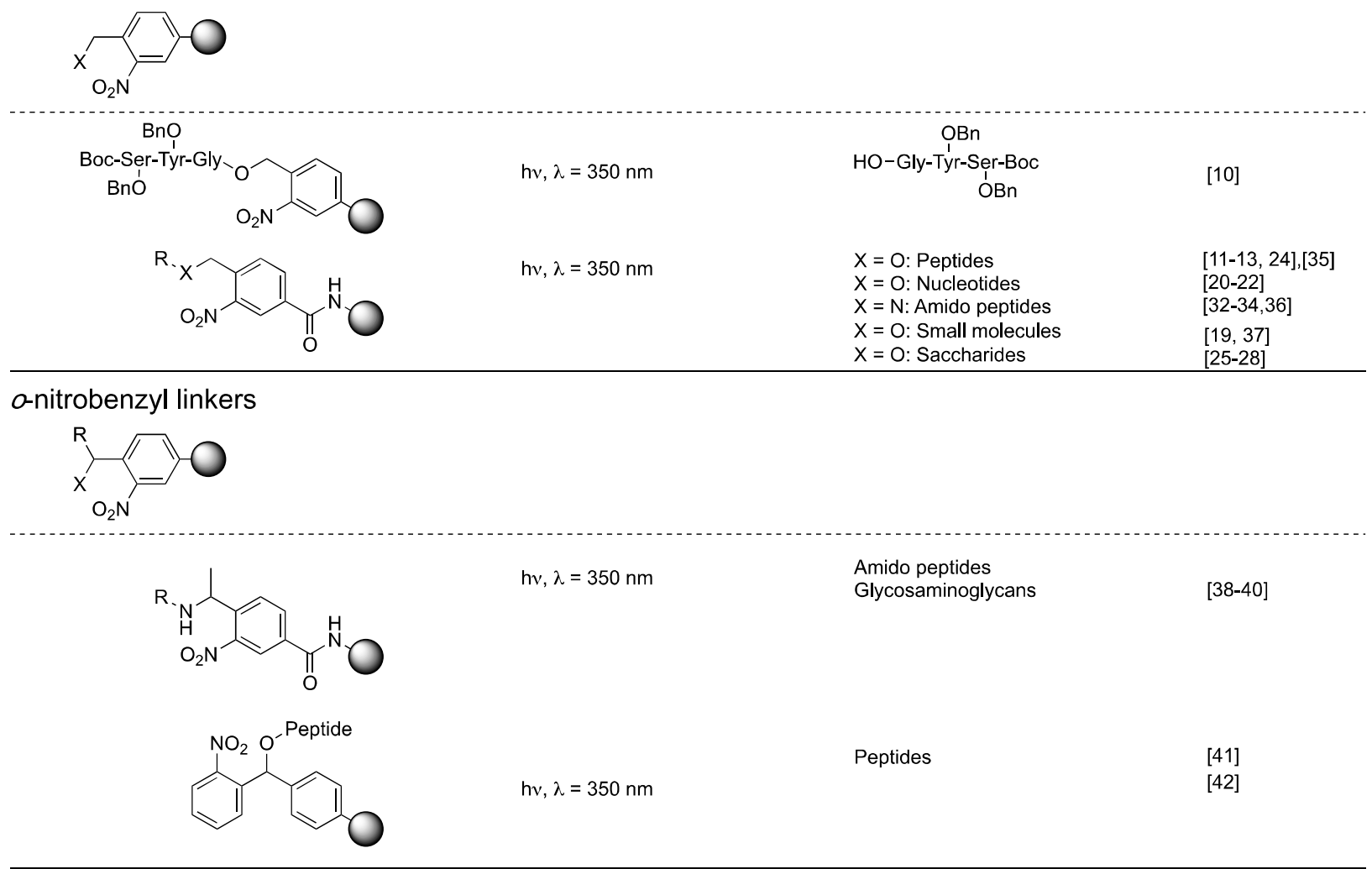

\section{o-Nitroveratryl linkers}
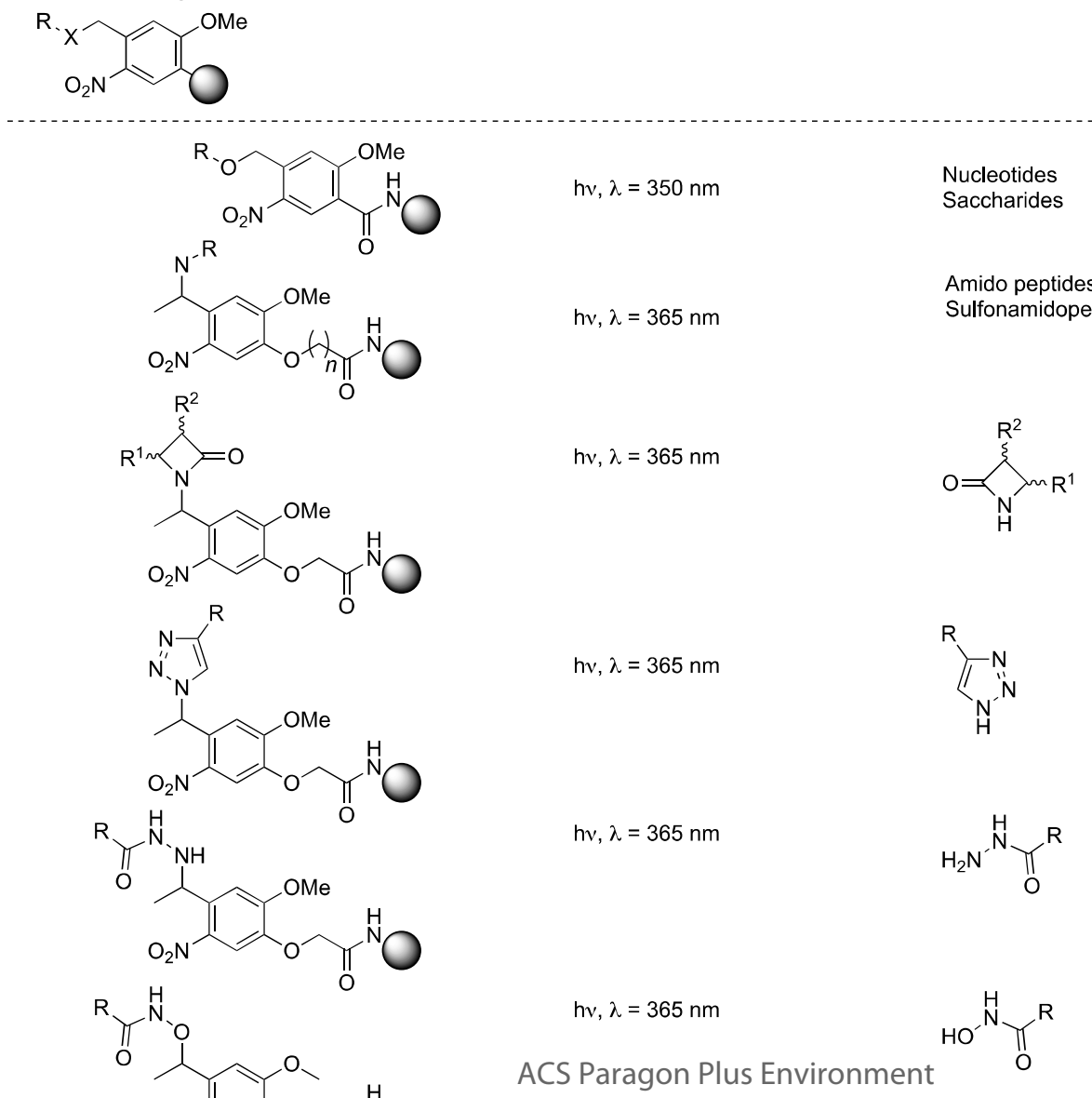

$[49],[51-52]$ 
ACS Combinatorial Science

Page 44 of 104

1
2
3
3
4
5
6
7
7
8
9

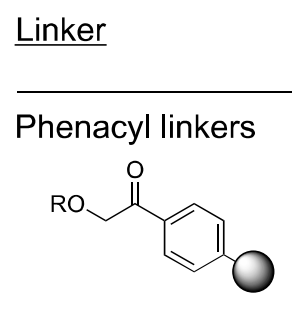

$\begin{array}{ll}\text { Cleavage } & \text { Product } \\ \text { Conditions } & \end{array}$

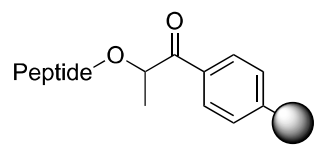

$\mathrm{hv}, \lambda=300-350 \mathrm{~nm}$

Peptides

[67-69]

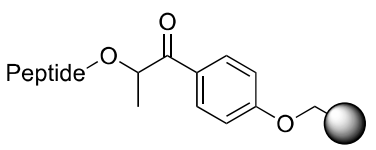

Peptides

[70-71]

Benzoin linkers
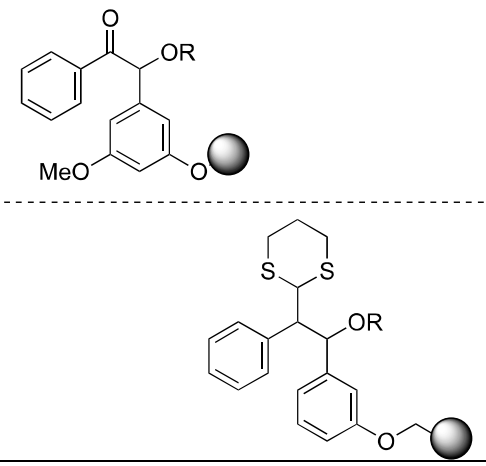

$\mathrm{hv}, \lambda=350 \mathrm{~nm}$

$\mathrm{h} v, \lambda=350 \mathrm{~nm}$

Unnatural amino acids

Pivaloyl linkers
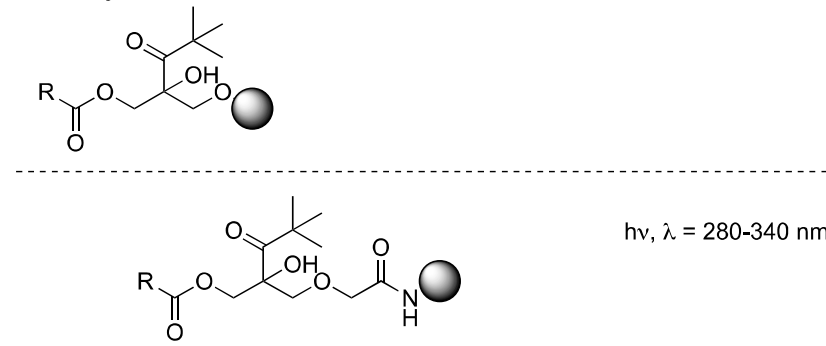

$\mathrm{hv}, \lambda=280-340 \mathrm{~nm}$

Peptides

Small molecules $\quad[80,82]$

[77]

[81]

Other photolabile

linkers

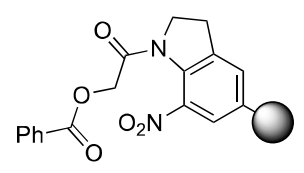

$\mathrm{h} v, \lambda=290 \mathrm{~nm}, \mathrm{R}^{1} \mathrm{R}^{2} \mathrm{NH}$<smiles>[R]N([R])C(=O)COC(=O)c1ccccc1</smiles>

[84]

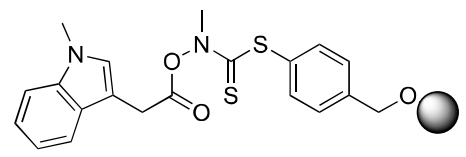

hr, $\lambda=350 \mathrm{~nm}$, $\mathrm{Bu}_{3} \mathrm{SnH}$, WHF

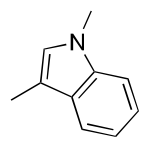

[83)

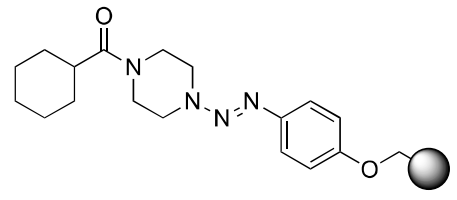

$\mathrm{h} v, \lambda=355 \mathrm{~nm}$

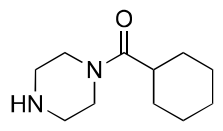

[85)

ACS Paragon Plus Environment

44 
Table 1. Summary of current photocleavable linker strategies for solid-phase syntheses.

\title{
Conclusions
}

More than 40 years have passed since the first publication of a photolabile linker. A wide range of photolabile linkers has since been developed to provide an extensive toolkit for the synthesis of peptides, oligosaccharides, oligonucleotides and small molecules. Photolabile linkers provide a mode of cleavage, which is orthogonal to reaction conditions normally applied with traditional linkers. Furthermore, these linkers are normally cleaved under very mild conditions, which make them attractive for use to release material directly in buffers used for biological studies,[86] and for synthesis circumventing excessive amounts of acidic cleavage reagents. It is expected that the field will expand alongside emerging lighting technologies, such as LED-based systems, which are now being recognized as unique enablers of photochemical organic reactions.

\section{AUTHOR INFORMATION}

Corresponding Author

*Thomas E. Nielsen, e-mail: ten@kemi.dtu.dk.

*Katrine Qvortrup, e-mail: kaqvo@kemi.dtu.dk.

\begin{abstract}
ABBREVIATIONS
Acm, acetamido; ANP, 3-amino-3-(2-nitrophenyl)propionyl; BME, $\beta$-mercaptoethanol; Bn, benzyl; Boc, t-butyloxycarbonyl; BOP, benzotriazol-1-yl-oxy-tris(dimethylamino)phosphonium
\end{abstract}


hexafluorophosphate; BrZ, 2-bromobenzyloxycarbonyl; Bzl, benzyl; ClZ, 2chlorobenzyloxycarbonyl; DCC, N,N'-dicyclohexylcarbodiimide; DCE, dichloroethane; DDQ, 2,3-dichloro-5,6-dicyano-1,4-benzoquinone; DIC, N,N'-diisopropylcarbodiimide; DIEA, N,Ndiisopropylethylamine; DKP, diketopiperazine; DMAP, 4-dimethylaminopyridine; DMB, 3',5'dimethoxybenzoin; DMF, dimethylformamide; DMP, 2,5-dimethylphenacyl; DMTr, 4,4'dimethoxytrityl; $\quad$ Fmoc, (9-fluorenylmethyl) carbamate; HATU, Hexafluorophosphate Azabenzotriazole Tetramethyl Uronium; HOBt, 1-hydroxybenzotriazole; LCAA-CPG, long chain aminoalkyl controlled pore glass; LED, light-emitting diode; LG, leaving group; MBHA, 4-Methylbenzhydrylamine; NBB, (3-nitrobenzamido)benzyl; NBH, 2nitrobenzhydryl; NBOC, 2-nitrobenzyloxycarbonyl; NBS, N-bromosuccinimide; NMM, Nmethylmorpholine; NMP, N-methylpyrrolidone; NVOC, 6-nitroveratryloxycarbonyl; PEG, polyethylene glycol; PPOA, [4-(2-bromopropionyl)phenoxy]acetic acid; PS, polystyrene; SPPS, solid-phase peptide synthesis; SPOS, solid-phase organic synthesis; TBDPS, tetrabutyldiphenylsilyl; $\quad$ TBTU, $\quad$ O-(benzotriazol-1-yl)-N, $, \mathrm{N} \mathrm{N}^{\prime}, \mathrm{N}^{\prime}$-tetramethyluronium tetrafluoroborate; TFA, trifluoroacetic acid; TFP, tri-2-Furylphosphine; THF, tetrahydrofuran; Thy, thymine; TCA, trichloroacetic acid; TLC, thin layer chromatography; Tos, ptoluenesulfonyl; UNP-Gal, uridine diphosphate galactose; Z, carbobenzyloxy (benzyloxycarbonyl).

\section{REFERENCES}

[1]: Merrifield, R. B. Solid Phase Peptide Synthesis. I. The Synthesis of a Tetrapeptide. J. Am. Chem. Soc. 1963, 85, 2149-2154. 
[2]: Testero, S. A.; Mata, E. G. J. Prospect of Metal-Catalyzed C-C Forming Cross-Coupling Reactions in Modern Solid-Phase Organic Synthesis. Comb. Chem. 2008, 10, 487-497.

[3]: Hermkens, P. H. H.; Ottenheijm, H. C. J.; Rees, D. Solid-phase organic reactions: A review of the recent literature. Tetrahedron 1996, 52, 4527-4554.

[4]: Hermkens, P. H. H.; Ottenheijm, H. C. J.; Rees, D. C. Solid-phase organic reactions II: A review of the literature Nov 95-Nov 96. Tetrahedron 1997, 53, 5643-5678.

[5]: Booth, S.; Hermkens, P. H. H.; Ottenheijm, H. C. J.; Rees, D. C. Solid-phase organic reactions III: A review of the literature Nov 96-Dec 97. Tetrahedron 1998, 54, 15385-15443.

[6]: Hall, S. E. Recent advances in solid phase synthesis. Mol. Divers. 1999, 4, 131-142.

[7]: Dolle, R. E.; Nelson, K. H., Jr. Comprehensive Survey of Combinatorial Library Synthesis: 1998. J. Comb. Chem. 1999, 1, 235-282.

[8]: Taylor, S. J.; Morken, J. P. Thermographic Selection of Effective Catalysts from an Encoded Polymer-Bound Library. Science 1998, 280, 267-270.

[9]: Bamford, C. H.; Norrish, R. G. W. Primary Photochemical Reactions. Part VII. Photochemical Decomposition of Isovaleraldehyde and Di-n-propyl Ketone. J. Chem. Soc. 1935, 1504-1511.

[10]: Rich, D. H.; Gurwara, S. K. J. Removal of protected peptides from an ortho-nitrobenzyl resin by photolysis. Chem. Soc., Chem. Commun. 1973, 610-611. 
[11]: Rich, D. H.; Gurwara, S. K. Preparation of a new o-nitrobenzyl resin for solid-phase synthesis of tert-butyloxycarbonyl-protected peptide acids. J. Am. Chem. Soc. 1975, 97, 15751579.

[12]: Tam, J. P.; Tjoeng, F. S.; Merrifield, R. B. Design and synthesis of multidetachable resin supports for solid-phase peptide synthesis. J. Am. Chem. Soc. 1980, 102, 6117-6127.

[13]: Voss, C; Dimarchi, R; Whitney, D. B. ; Tjoeng, F. S.; Merrifield, R. B.; Tam, J. P. Synthesis of the protected tridecapeptide (56-68) of the $\mathrm{VH}$ domain of mouse myeloma immunoglobulin M603 and its reattachment to resin supports. Int. J. Pept. Protein Res. 1983, 22, 204-213.

[14]: Barany, G.; Albericio, F. Three-dimensional orthogonal protection scheme for solidphase peptide synthesis under mild conditions. J. Am. Chem. Soc. 1985, 107, 4936-4942.

[15]: Giralt, E.; Albericio, F.; Pedroso, E.; Granier, C.; Van Rietschoten, J. Convergent solid phase peptide synthesis. II. Synthesis of the 1-6 apamin protected segment on a NBB-resin. Synthesis of apamin. Tetrahedron 1982, 38, 1193-1201.

[16]: Giralt, E.; Eritja, R.; Pedroso, E. Convergent solid phase peptide synthesis-III: Synthesis of the 44-52 protected segment of the toxin II of androctonus australis hector. Tetrahedron 1986, $42,691-698$.

[17]: Lloyd-Williams, P.; Gairi, M.; Albericio, F.; Giralt, E. Convergent solid-phase peptide synthesis. X. Synthesis and purification of protected peptide fragments using the photolabile Nbb-resin. Tetrahedron 1991, 47, 9867-9880. 
[18]: Pillai, V. N. R.; Renil, M.; Haridasan, V. K. Synthesis of thioredoxin partial sequences on a polyethyleneglycol-grafted polystyrene support with a photolytically detachable 2-nitrobenzyl anchoring group. Indian J. Chem., Sect. B 1991, 30B, 205-212.

[19]: Baldwin, J. J.; Burbaum, J. J.; Henderson, I.; Ohlmeyer, M. H. J. Synthesis of a Small Molecule Combinatorial Library Encoded with Molecular Tags. J. Am. Chem. Soc. 1995, 117, 5588-5589.

[20]: Greenberg, M. M. Photochemical cleavage of oligonucleotides from solid phase supports. Tetrahedron Lett. 1993, 34, 251-254.

[21]: Matray, T. J.; Greenberg, M. M. Site-Specific Incorporation of the Alkaline Labile, Oxidative Stress Product (5R)-5,6-Dihydro-5-hydroxythymidine in an Oligonucleotide. J. Am. Chem. Soc. 1994, 116, 6931-6932.

[22]: Greenberg, M. M.; Gilmore, J. L. Cleavage of Oligonucleotides from Solid-Phase Supports Using o-Nitrobenzyl Photochemistry. J. Org. Chem. 1994, 59, 746-753.

[23]: Alsina, J.; Chiva, C.; Ortiz, M.; Francesc, R.; Giralt, E.; Albericio, F. Active carbonate resins for solid-phase synthesis through the anchoring of a hydroxyl function. Synthesis of cyclic and alcohol peptides. Tetrahedron Lett. 1997, 38, 883-886.

[24]: Tam, J. P.; Dimarchi, R. D.; Merrifield, R. B. Photolabile multi-detachable $p$ alkoxybenzyl alcohol resin supports for peptide fragment or semi-synthesis. Int. J. Pept. Protein Res. 1980, 16, 412-425. 
[25]: Zehavi, U.; Sadeh, S.; Herchman, M. Enzymic synthesis of oligosaccharides on a polymer support light-sensitive, substituted polyacrylamide beads. Carbohydr. Res. 1983, 124, 23-34.

[26]: Nicolaou, K. C.; Winssinger, N.; Pastor, J.; DeRoose, F. A General and Highly Efficient Solid Phase Synthesis of Oligosaccharides. Total Synthesis of a Heptasaccharide Phytoalexin Elicitor (HPE). J. Am. Chem. Soc. 1997, 119, 449-450.

[27]: Nicolaou, K. C.; Watanabe, N.; Li, J.; Pastor, J.; Winssinger, N. Solid-phase synthesis of oligosaccharides: construction of a dodecasaccharide. Angew. Chem. Int. Ed. 1998, 37, 15591561.

[28]: Kantchev, E. A. B.; Parquette, J. R. Hyper-branched polyester supported disaccharide synthesis: The effect of loading level on glycosylation efficiency Synlett 2005, 1567-1570.

[29]: Armstrong, R. W.; Combs, A. P.; Tempest, P. A.; Brown, S. D.; Keating, T. A. MultipleComponent Condensation Strategies for Combinatorial Library Synthesis. Acc. Chem. Res. 1996, 29, 123-131.

[30]: Johnsson, R; Lackey, J. G.; Bogojeski, J. J.; Damha, M. J. New light labile linker for solid phase synthesis of 2'-O-acetal-ester oligonucleotides and applications to siRNA prodrug development. Bioorg. Med. Chem. Lett. 2011, 21, 3721-3725.

[31]: Hasan, A; Stengele, K.-P.; Giegrich, H.; Cornwell, P.; Isham, K. R; Sachleben, R. A.; Pfleiderer, W.; Foote, R. S. Photolabile protecting groups for nucleosides: synthesis and photodeprotection rates. Tetrahedron 1997, 53, 4247-4264. 
[32]: Rich, D. H.; Gurwara, S. K. Removal of C-terminal peptide amides from a 3-nitro-4aminomethyl-benzoyl amide resin by photolysis. Tetrahedron Lett. 1975, 16, 301-304.

[33]: Hammer, R. P.; Albericio, F.; Gera, L.; Barany, G. Practical approach to solid-phase synthesis of C-terminal peptide amides under mild conditions based on a photolysable anchoring linkage. Int. J. Pept. Protein Res. 1990, 36, 31-45.

[34]: Ajayaghosh, A.; Pillai, V. N. R. Solid-phase synthesis of N-methyl- and N-ethylamides of peptides using photolytically d(3-nitro-4[(alkylamino)methyl]benzamido]methyl]polystyrene resin. J. Org. Chem. 1990, 55, 2826-2829.

[35]: Renil, M.; Pillai, V. N. R. Synthesis of fully protected peptides on a tetraethyleneglycol diacrylate (TTEGDA)-crosslinked polystyrene support with a photolytically detachable 2nitrobenzyl anchoring group. Tetrahedron Lett. 1994, 35, 3809-3812.

[36]: Kumar, K. S.; Pillai, V. N. R. Synthesis of peptide-N-alkylamides on a new PS-TTEGDA polymer support using photolabile anchoring group. Tetrahedron 1999, 55, 10437-10446.

[37]: Hintersteiner, M.; Ambrus, G.; Bednenko, J.; Schmied, M.; Knox, A. J. S.; Meisner, N.C.; Gstach, H.; Seifert, J.-M.; Singer, E. L.; Gerace, L.; Auer, M. Identification of a Small Molecule Inhibitor of Importin $\beta$ Mediated Nuclear Import by Confocal On-Bead Screening of Tagged One-Bead One-Compound Libraries. ACS Chem. Biol. 2010, 5, 967-979.

[38]: Eller, S.; Collot, M.; Yin, J.; Hahm, H. S.; Seeberger, P. H. Automated Solid-Phase Synthesis of Chondroitin Sulfate Glycosaminoglycans. Angew. Chem. Int. Ed. 2013, 52, 58585861. 
[39]: Calin, O; Eller, S.; Seeberger, P. H. Automated Polysaccharide Synthesis: Assembly of a 30mer Mannoside. Angew. Chem. Int. Ed. 2013, 52, 5862-5865.

[40]: Weishaupt, M. W.; Matthies, S.; Seeberger, P. H. Automated Solid-Phase Synthesis of a $\beta$-(1,3)-Glucan Dodecasaccharide. Chem. Eur. J. 2013, 19, 12497-12503.

[41]: Ajayaghosh, A; Pillai, V. N. R. Polymer-supported synthesis of protected peptide segments on a photosensitive o-nitro(a-methyl)bromobenzyl resin. Tetrahedron 1988, 44, 66616666.

[42]: Ajayaghosh, A; Pillai, V. N. R. 2'-Nitrobenzhydryl polystyrene resin: a new photosensitive polymeric support for peptide synthesis. J. Org. Chem. 1987, 52, 5714-5717.

[43]: Ajayaghosh, A; Pillai, V. N. R. Solid-phase synthesis and C-terminal amidation of peptides using a photolabile o-nitrobenzhydrylaminopolystyrene support. Tetrahedron Lett. 1995, 36, 777-780.

[44]: Brown, B. B.; Wagner, D. S.; Geysen, H. M. A single-bead decode strategy using electrospray ionization mass spectrometry and a new photolabile linker: 3-Amino-3-(2nitrophenyl)propionic acid. Mol. Div. 1995, 1, 4-12

[45]: Sternson, S. M.; Schreiber, S. L. An acid- and base-stable o-nitrobenzyl photolabile linker for solid phase organic synthesis. Tetrahedron Lett. 1998, 39, 7451-7454.

[46]: Rodebaugh, R.; Fraser-Reid, B.; Geysen, H. M. A new o-nitrobenzyl photocleavable linker for solid phase synthesis. Tetrahedron Lett. 1997, 97, 7653-7656. 
[47]: Ryba, T. D.; Harran, P. G. Two Useful Photolabile Surfaces for Solid-Phase Synthesis. Org. Lett. 2000, 2, 851-853.

[48]: Zehavi, U.; Patchornik, A. Oligosaccharide synthesis on a light-sensitive solid support. I. Polymer and synthesis of isomaltose (6-O-.alpha.-D-glucopyranosyl-D-glucose). J. Am. Chem. Soc. 1973, 95, 5673-5677.

[49]: Yoo, D. J.; Greenberg, M. M. Synthesis of Oligonucleotides Containing 3'-Alkyl Carboxylic Acids Using Universal, Photolabile Solid Phase Synthesis Supports. J. Org. Chem. 1995, 60, 3358-3364.

[50]: Holmes, C. P.; Jones, D. G. Reagents for Combinatorial Organic Synthesis: Development of a New o-Nitrobenzyl Photolabile Linker for Solid Phase Synthesis. J. Org. Chem. 1995, 60, $2318-2319$.

[51]: Venkatesan, H.; Greenberg, M. M. Improved Utility of Photolabile Solid Phase Synthesis Supports for the Synthesis of Oligonucleotides Containing 3‘-Hydroxyl Termini. J. Org. Chem. 1996, 61, 525-529.

[52]: Poijaervi, P.; Heinonen, P.; Virta, P.; Loennberg, H. 2,2-Bis(ethoxycarbonyl)- and 2(Alkylaminocarbonyl)-2-cyano-Substituted 3-(Pivaloyloxy)propyl Groups as Biodegradable Phosphate Protections of Oligonucleotides. Bioconjugate Chem. 2005, 16, 1564-1571.

[53]: Holmes, C. P. Model Studies for New o-Nitrobenzyl Photolabile Linkers: Substituent Effects on the Rates of Photochemical Cleavage. J. Org. Chem. 1997, 62, 2370-2380. 
[54]: Teague, S. J. Facile synthesis of a o-nitrobenzyl photolabile linker for combinatorial chemistry. Tetrahedron Lett. 1996, 37, 5751-5754.

[55]: Whitehouse, D. L.; Savinov, S. N.; Austin, D. J. An improved synthesis and selective coupling of a hydroxy based photolabile linker for solid phase organic synthesis. Tetrahedron Lett. 1997, 38, 7851-7852.

[56]: McKeown, S. C.; Watson, S. P.; Carr, R. A. E.; Marshall, P. A photolabile carbamate based dual linker analytical construct for facile monitoring of solid phase chemistry: 'TLC' for solid phase? Tetrahedron Lett. 1999, 40, 2407-2410.

[57]: Gea, A.; Farcy, N.; Roqué I Rossell, N.; Martins, J. C.; De Clercq, P. J.; Madder, A. Solid-Supported Synthesis of Highly Functionalized Tripodal Peptides with Flexible but Preorganized Geometry: Towards Potential Serine Protease Mimics. Eur. J. Org. Chem. 2006, 4135-4146.

[58]: Lin, Q.; Blackwell, H. E. Rapid synthesis of diketopiperazine macroarrays via Ugi fourcomponent reactions on planar solid supports. Chem. Commun. 2006, 2884-2886.

[59]: Gennari, C.; Longari, C.; Ressel, S.; Salom, B.; Piarulli, U.; Ceccarelli, S.; Mielgo, A. Synthesis of Combinatorial Libraries of Vinylogous Sulfonamidopeptides (vs-Peptides). Eur. J. Org. Chem. 1998, 2437-2449.

[60]: Ruhland, B.; Bhandari, A.; Gordon, E. M.; Gallop, M. A. Solid-Supported Combinatorial Synthesis of Structurally Diverse $\beta$-Lactams. J. Am. Chem. Soc. 1996, 118, 253-254. 
[61]: Minkwitz, R.; Meldal, M. Application of a Photolabile Backbone Amide Linker for Cleavage of Internal Amides in the Synthesis towards Melanocortin Subtype-4 Agonists. QSAR Comb. Sci. 2005, 24, 343-353.

[62]: Qvortrup, K; Nielsen, T. E. A photolabile linker for the solid-phase synthesis of 4substituted NH-1,2,3-triazoles. Chem. Commun. 2011, 47, 3278-3280.

[63]: Qvortrup, K; Komnatnyy, V. V.; Nielsen, T. E. A Photolabile Linker for the Solid-Phase Synthesis of Peptide Hydrazides and Heterocycles. Org. Lett. 2014, 16, 4782-4785.

[64]: Qvortrup, K; Nielsen, T. E. In-Bead Screening of Hydroxamic Acids for the Identification of HDAC Inhibitors. Angew. Chem. Int. Ed. Engl. 2016, 14, 4472-4475.

[65]: Qvortrup, K.; Petersen, R. G.; Dohn, A. O.; Møller, K. B.; Nielsen, T. E. SolventControlled Chemoselectivity in the Photolytic Release of Hydroxamic Acids and Carboxamides from Solid Support. Org. Lett. 2017, 12, 3263-3266.

[66]: Kim, J.; Kyeong, S.; Shin, D.-S.; Yeo, S.; Yim, J.; Lee, Y.-S. Facile Synthesis of N-(9Fluorenylmethyloxycarbonyl)-3-amino-3-(4,5-dimethoxy-2-nitrophenyl)propionic Acid as a Photocleavable Linker for Solid-Phase Peptide Synthesis. Synlett 2013, 733-736.

[67]:Sheehan , J.C.; Umezawa , K. Phenacyl photosensitive blocking groups, J. Org. Chem. 1973, 38, 3771-3774.

[68]: Wang, S.-S.; Solid phase synthesis of protected peptides via photolytic cleavage of the .alpha.-methylphenacyl ester anchoring linkage. J. Org. Chem. 1976, 41, 3258-3261. 
[69]: Tjoeng, F. S.; Heavner, G. A. Synthesis of a new photolabile support. 4-(2Chloropropionyl)phenylacetamidomethyl-resin and its application in solid-phase peptide synthesis. J. Org. Chem. 1983, 48, 355-359.

[70]: Bellof, D.; Mutter, M. A new phenacyl-type handle for polymer supported peptide synthesis. Chimia 1985, 39, 317-320.

[71]: Abraham, N. A.; Fazal, G.; Ferland, J. M.; Rakhit, S.; Gauthier, J. A new solid-phase strategy for the synthesis of mammalian glucagon. Tetrahedron Lett. 1991, 32, 577-580.

[72]: Flickinger, S. T.; Patel, M.; Binkowski, B. F. ; Lowe, A. M.; Li, M.-H.; Kim, C.; Cerrina, F.; Belshaw, P. J. Spatial Photorelease of Oligonucleotides, Using a Safety-Catch Photolabile Linker. Org. Lett. 2006, 8, 2357-2360.

[73]: Sucholeiki, I. Solid-phase photochemical C-S bond cleavage of thioethers-a new approach to the solid-phase production of non-peptide molecules. Tetrahedron Lett. 1994, 35 , $7307-7310$.

[74]: Forman, F. W.; Sucholeiki, I. Solid-Phase Synthesis of Biaryls via the Stille Reaction. J. Org. Chem. 1995, 60, 523-528.

[75]: Rock, R. S.; Chan, S. I. Synthesis and Photolysis Properties of a Photolabile Linker Based on 3'-Methoxybenzoin. J. Org. Chem. 1996, 61, 1526-1529.

[76]: Routledge, A.; Abell, C.; Balasubramanian, S. The use of a dithiane protected benzoin photolabile safety catch linker for solid-phase synthesis. Tetrahedron Lett. 1997, 38, 1227-1230. 
[77]: Lee, H. B.; Balasubramanian, S. Studies on a Dithiane-Protected Benzoin Photolabile Safety Catch Linker for Solid-Phase Synthesis. J. Org. Chem. 1999, 64, 3454-3460.

[78]: Cano, M.; Ladlow, M.; Balasubramanian, S. Practical Synthesis of a Dithiane-Protected 3‘,5'-Dialkoxybenzoin Photolabile Safety-Catch Linker for Solid-Phase Organic Synthesis. J. Org. Chem. 2002, 67, 129-135

[79]: Chumachenko, N.; Novikov, Y; Shoemaker, R. K.; Copley, S. D. A Dimethyl KetalProtected Benzoin-Based Linker Suitable for Photolytic Release of Unprotected Peptides. J. Org. Chem 2011, 76, 9409-9416.

[80]: Peukert, S.; Giese, B. The Pivaloylglycol Anchor Group: A New Platform for a Photolabile Linker in Solid-Phase Synthesis. J. Org. Chem. 1998, 63, 9045-9051.

[81]: Glatthar, R. Giese, B. A New Photocleavable Linker in Solid-Phase Chemistry for Ether Cleavage. Org. Lett. 2000, 2, 2315-2317.

[82]: Kessler, M.; Glatthar, R.; Giese, B.; Bochet, C. G. Sequentially Photocleavable Protecting Groups in Solid-Phase Synthesis. Org. Lett. 2003, 5, 1179-1181.

[83]: Horton, J. R.; Stamp, L. M.; Routledge, A. A photolabile 'traceless' linker for solid-phase organic synthesis. Tetrahedron Lett. 2000, 41, 9181-9184.

[84]: Nicolaou, K. C.; Safina, B. S.; Winssinger, N. A new photolabile linker for the photoactivation of carboxyl groups. Synlett 2001, 900-903.

[85]: Enders, D. Rijksen, C.; Bremus-Köbberling, E.; Gillner, A.; Köbberling, J. A triazenebased new photolabile linker in solid phase chemistry. Tetrahedron Lett. 2004, 45, 2839-2841. 
[86]: (a) Fluxà, V. S.; Maillard, N.; Page, M. G. P.; Reymond, J.-L. Bead diffusion assay for discovering antimicrobial cyclic peptides. Chem. Commun. 2011, 47, 1434-1436. (b) Shin, D.; Kim, Y.-G.; Kim, E.-M.; Kim, M.; Park, H.; Kim, J.-H.; Lee, B.-S.; Kim, B.; Lee, Y. SolidPhase Peptide Library Synthesis on HiCore Resin for Screening Substrate Specificity of Brk Protein Tyrosine Kinase. J. Comb. Chem. 2008, 10, 20-23. (c) Guillena, G.; Halkes, K. M.; Rodríguez, G.; Batema, G. D.; van Koten, G.; Kamerling, J. P. Organoplatinum(II) Complexes as a Color Biomarker in Solid-Phase Peptide Chemistry and Screening. Org. Lett. 2003, 5, 20212024. (d) Johannesson, P.; Erdélyi, M.; Lindeberg, G.; Frändberg, P.-A.; Nyberg, F.; Karlén, A.; Hallberg, A. Bicyclic Tripeptide Mimetics with Reverse Turn Inducing Properties. J. Med. Chem. 2004, 47, 6009-6019. (e) Miyashita, M.; Otake, Y.; Oda, M.; Miyagawa, H. Development of a High-Throughput Screening Method Using a Cell-Based, Lawn Format Assay for the Identification of Novel Plant Defense Activators from Combinatorial Peptide Libraries. J. Agric. Food Chem. 2007, 55, 806-811. (f) Maillard, N.; Biswas, R.; Darbre, T.; Reymond, J.-L. Combinatorial Discovery of Peptide Dendrimer Enzyme Models Hydrolyzing Isobutyryl Fluorescein. ACS Comb. Sci. 2011, 13, 310-320. (g) Maillard, N.; Darbre, T.; Reymond, J.-L. Combinatorial discovery of peptide dendrimer enzyme models hydrolyzing isobutyryl fluorescein. J. Comb. Chem. 2009, 11, 667-675. (h) Tornøe, C. W.; Sanderson, S. J.; Mottram, J. C.; Coombs, G. H.; Meldal, M. Combinatorial Library of Peptidotriazoles: Identification of [1,2,3]-Triazole Inhibitors against a Recombinant Leishmania mexicana Cysteine Protease. $J$. Comb. Chem. 2004, 6, 312-324. (i) Usui, K.; Kikuchi, T.; Tomizaki, K.; Kakiyama, T.; Mihara, H. A novel array format for monitoring cellular uptake using a photo-cleavable linker for peptide release. Chem. Commun. 2013, 49, 6394-6396. (j) Zhou, G.; Khan, F.; Dai, Q.; Sylvester, J. E.; Kron, S. J. Photocleavable peptide-oligonucleotide conjugates for protein kinase 


\section{Graphical Abstract:}

Photolabile Linkers for Solid-Phase Synthesis

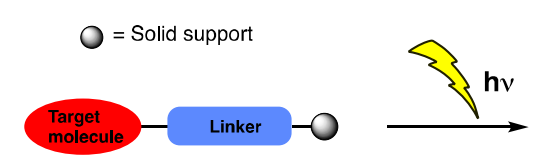

assays by MALDI-TOF MS. Mol. BioSyst. 2012, 8, 2395-2404. (k) Bodé, C. A; Bechet, T.; Prodhomme, E.; Gheysen, K.; Gregoir, P.; Martins, J. C.; Muller, C. P.; Madder, A. Towards the conformational mimicry of the measles virus HNE loop: design, synthesis and biological evaluation of a cyclic bile acid-peptide conjugate. Org. Biomol. Chem. 2009, 7, 3391-3399. (1) Verzele, D.; Madder, A. Synthetic Progress in cMyc-Max Oncoprotein Miniaturization: SemiOnline Monitoring Gives Solid-Phase Access to Hydrophobic b(-HLH-)ZIP Peptidosteroid Tweezers. Eur. J. Org. Chem. 2013, 673-687. (m) Boeijen, A.; Liskamp, R. M. J. Solid-Phase Synthesis of Oligourea Peptidomimetics. Eur. J. Org. Chem. 1999, 2127-2135. (n) Jang, K.; Sato, K.; Mawatari, K.; Konno, T.; Ishihara, K.; Kitamori, T. Surface modification by 2methacryloyloxyethyl phosphorylcholine coupled to a photolabile linker for cell micropatterning. Biomaterials 2009, 30, 1413-1420. 
<smiles>[R]C(c1cc(O)ccc1N(C)[O-])c1cc(O)ccc1[N+](=O)[O-]</smiles>

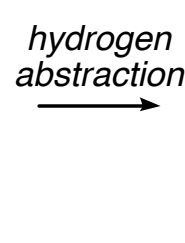<smiles>[R]C(Cl)c1cc(O)ccc1[N+]([O-])O</smiles><smiles></smiles><smiles>Oc1ccc2c(c1)C(Cl)(C(Cl)Cl)ON2O</smiles>

aci-nitro compound<smiles>CCCCC</smiles> 


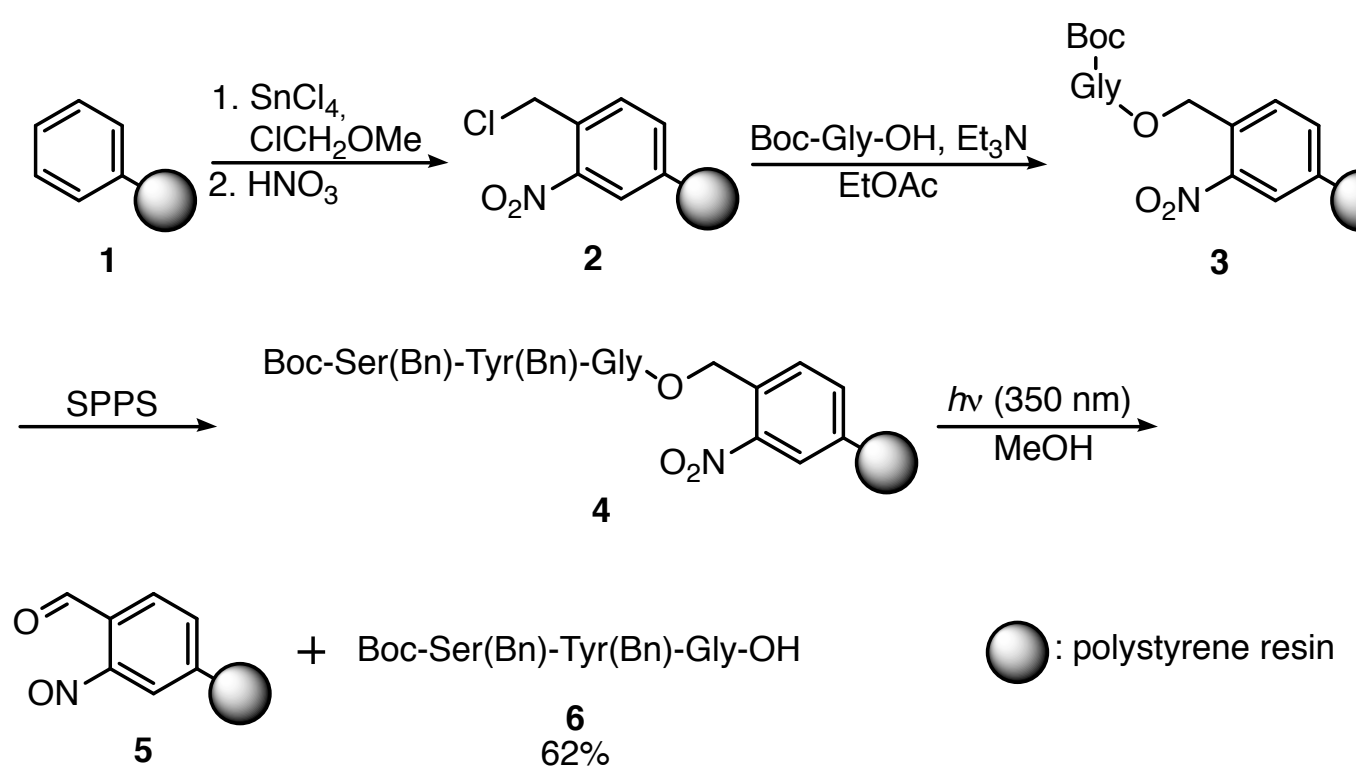


<smiles>Cc1ccc(C(=O)O)cc1</smiles>

1. NBS, $\left(\mathrm{PhCO}_{2}\right)_{2}$, benzene

2. $\mathrm{HNO}_{3}$ 7<smiles>NCc1ccc(OCC(=O)O)cc1</smiles><smiles>COc1ccc(COc2ccc(CNC(=O)c3ccc(Oc4ccc(CNC(=O)c5ccc(C(=O)NCc6ccc(CBr)c([N+](=O)[O-])c6)c([N+](=O)[O-])c5)cc4)cc3)cc2)cc1</smiles>

1. SPPS pGlu-His(Bn)-Trp-Ser(Bn)-Tyr(Bn)-Gly-Leu-Arg(Ts)-Pro-Gly-OH

2. $h v(350 \mathrm{~nm})$, 11 $\mathrm{MeOH}$

: polystyrene resin 


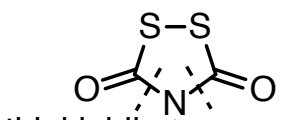

photolabile

thiol labile<smiles>COCc1ccc(C(=O)NCc2ccc(OC)cc2)cc1[N+](=O)[O-]</smiles>

12

acid labile

polystyrene resin 


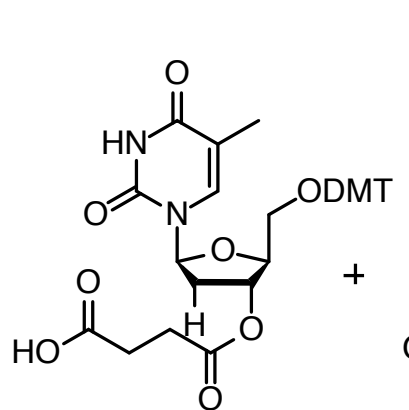

13<smiles>O=C(Oc1cc(Cl)c(Cl)cc1Cl)c1ccc(CO)c([N+](=O)[O-])c1</smiles><smiles>CCO[N+](=O)[O-]</smiles>
$\underset{\text { 2. } \mathrm{HMF}}{\stackrel{\mathrm{DOB}}{\mathrm{DMF}} \cdot \mathrm{H}_{2} \mathrm{O}, \mathrm{H}_{2} \mathrm{~N}-\mathrm{O}}$<smiles>O=CNC(=O)c1ccc(I)c([N+](=O)[O-])c1</smiles>

: LCAA-CPG 


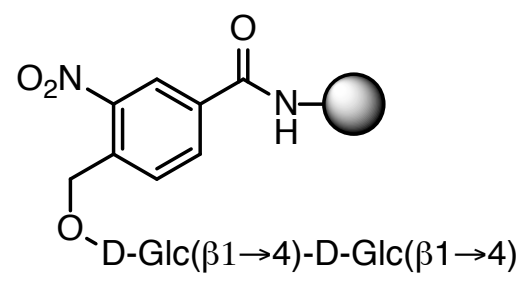

17 $\underset{\text { SDdium cacodylate buffer }}{\stackrel{\text { UDP-Gal, D-galactosyltransferase }}{\longrightarrow}}$

1. deprotection 2. EDCI, PLLDMF: $\mathrm{H}_{2} \mathrm{O}(2: 1)$ 16

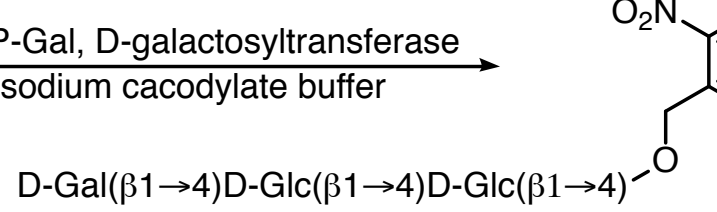

18

$D-G a l(\beta 1 \rightarrow 4) D-G l c(\beta 1 \rightarrow 4) D-G l c(\alpha / \beta)$

\section{9}

$0.87 \%$ 
<smiles>O=C(Oc1cc(Cl)c(Cl)cc1Cl)c1ccc(CO)c([N+](=O)[O-])c1</smiles>

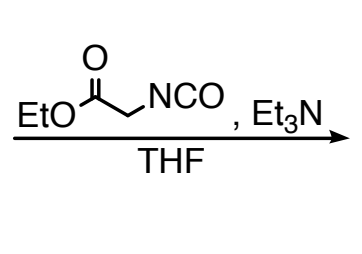<smiles>CCOC(=O)CNC(=O)OCc1ccc(C(=O)Oc2cc(Cl)c(Cl)cc2Cl)cc1[N+](=O)[O-]</smiles>

HOBt, MBHA-Gly resin<smiles>CCCC=CCCCC(=O)NCC(=O)NCC(=O)c1ccc(COC(=O)NCC(=O)O)c([N+](=O)[O-])c1</smiles>
18<smiles>CCCC(OC(=O)CNC(=O)OCc1ccc(C(=O)NCC(N)=O)cc1[N+](=O)[O-])C(=O)NCC(=O)OC</smiles>

$$
\mathrm{LiOH}
$$
22: $R=E t$

THF: $\mathrm{H}_{2} \mathrm{O} \longrightarrow$ 23: $\mathrm{R}=\mathrm{H}$ 
<smiles>CCOC(=O)c1ccc(C(C)COCC(C)C(F)(F)F)c([N+](=O)[O-])c1</smiles>

26

27

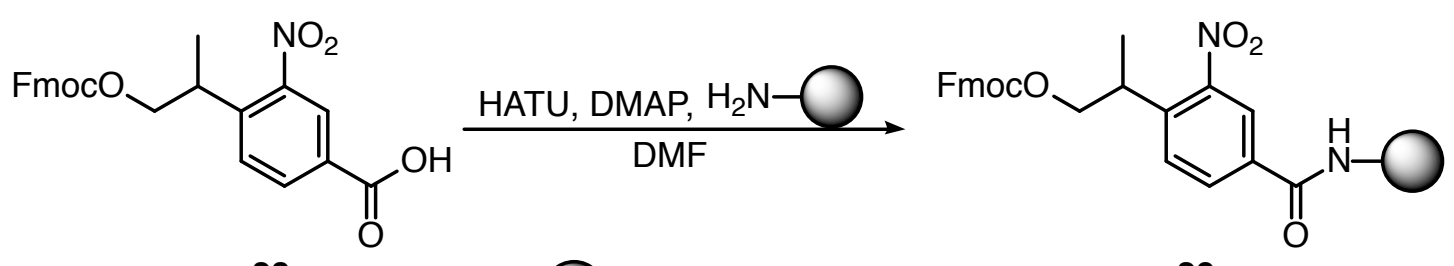

28

: LCAA-CPG

29

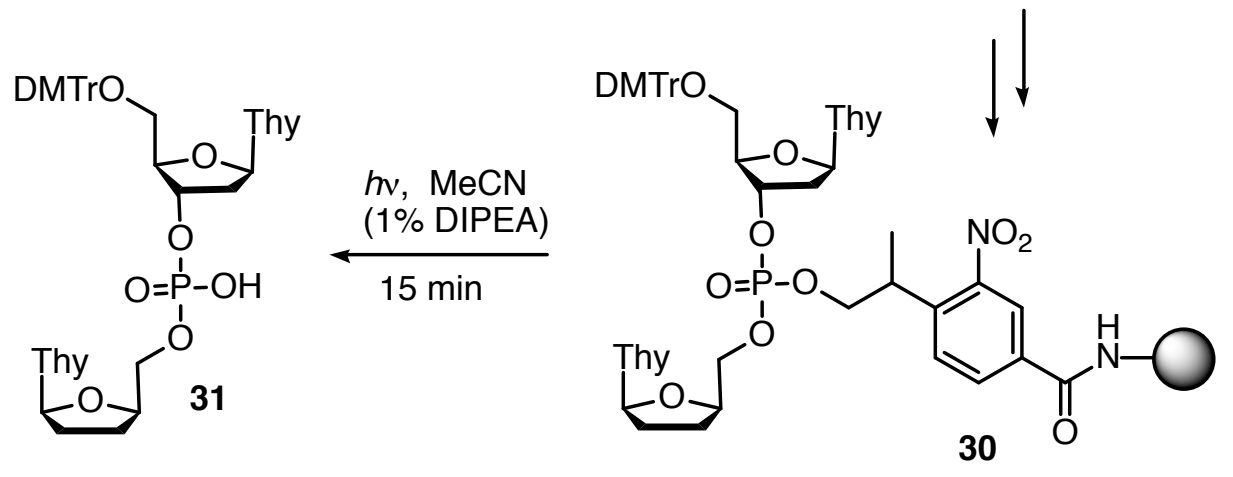




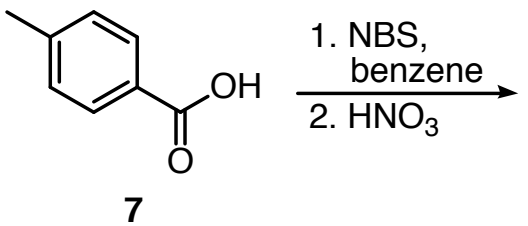<smiles>CC(N)(N)CCCC(=O)c1ccc(CBr)c([N+](=O)[O-])c1</smiles><smiles>O=C(NCc1ccc(C(=O)O)cc1[N+](=O)[O-])OCc1ccccc1</smiles>

32<smiles>O=C(NCc1ccc(C(=O)Nc2ccccc2)cc1[N+](=O)[O-])c1ccccc1</smiles>

33

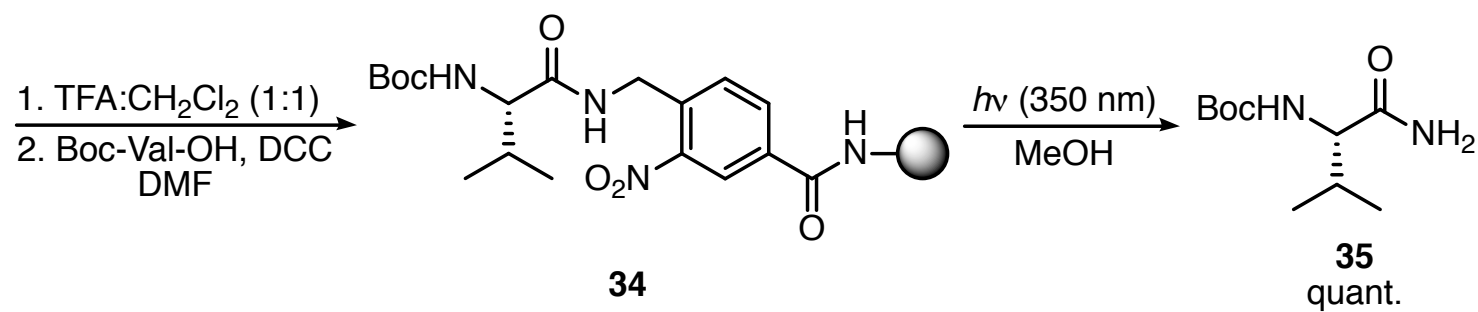

: aminomethyl polystyrene resin 


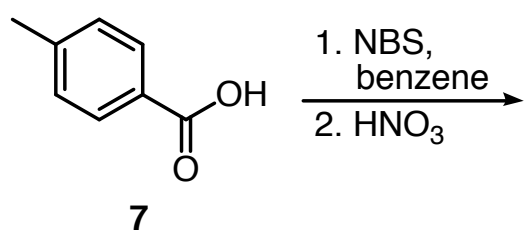<smiles>N[N+]([O-])([O-])CCC(=O)c1ccc(CBr)c([N+](=O)[O-])c1</smiles>

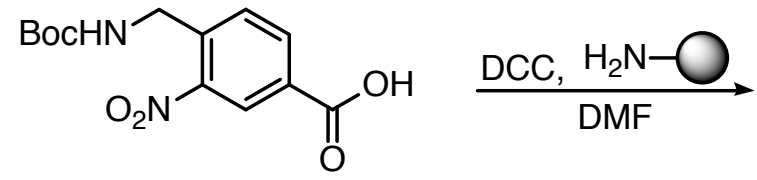

32<smiles>O=C(NCc1ccc(C(=O)Nc2ccccc2)cc1[N+](=O)[O-])c1ccccc1</smiles>

33

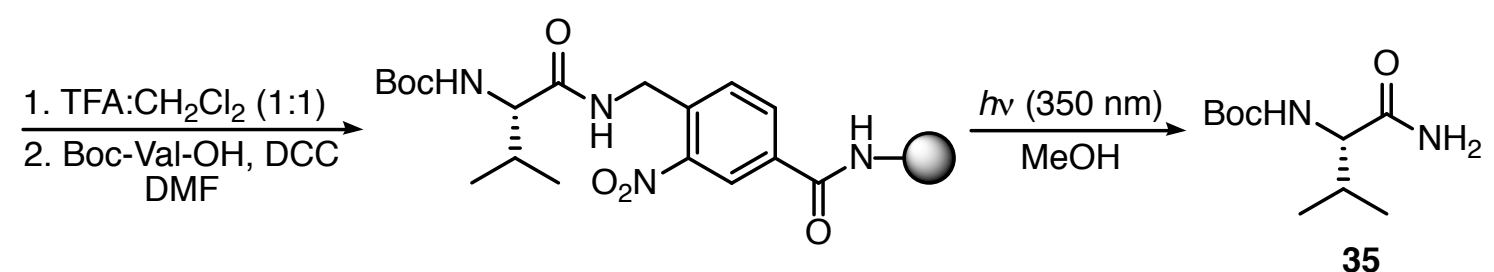

34 quant. 
<smiles>O=C(OCc1ccccc1)N(CCCCCO)Cc1cc(Oc2ccccc2)ccc1[N+](=O)[O-]</smiles>

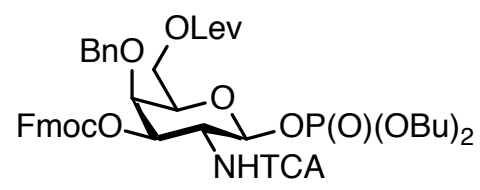

37

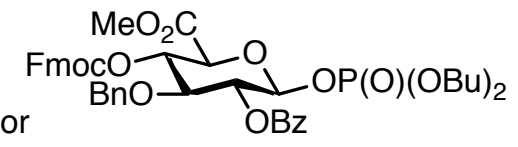

38

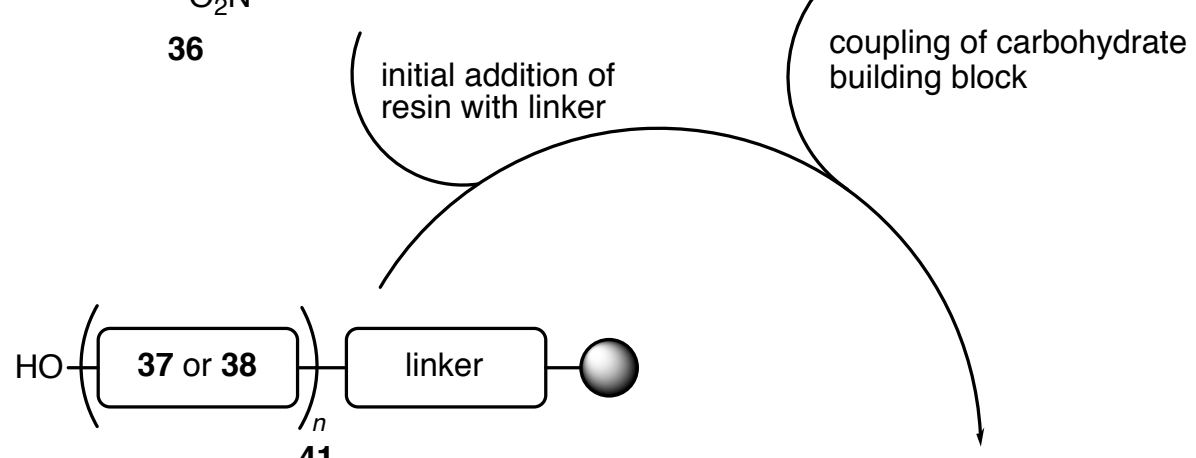

41
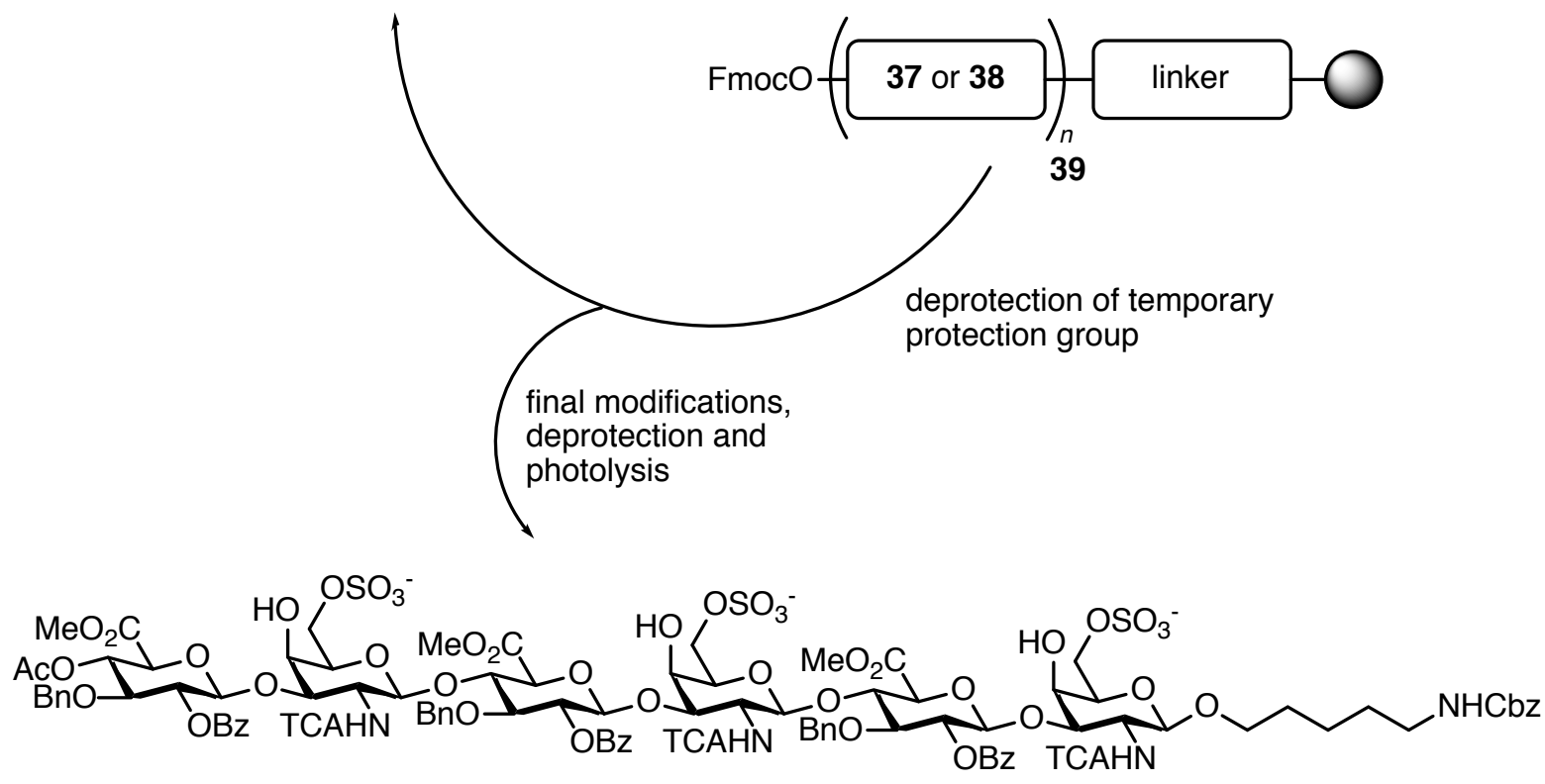

40

$13 \%$

Merrifield resin 


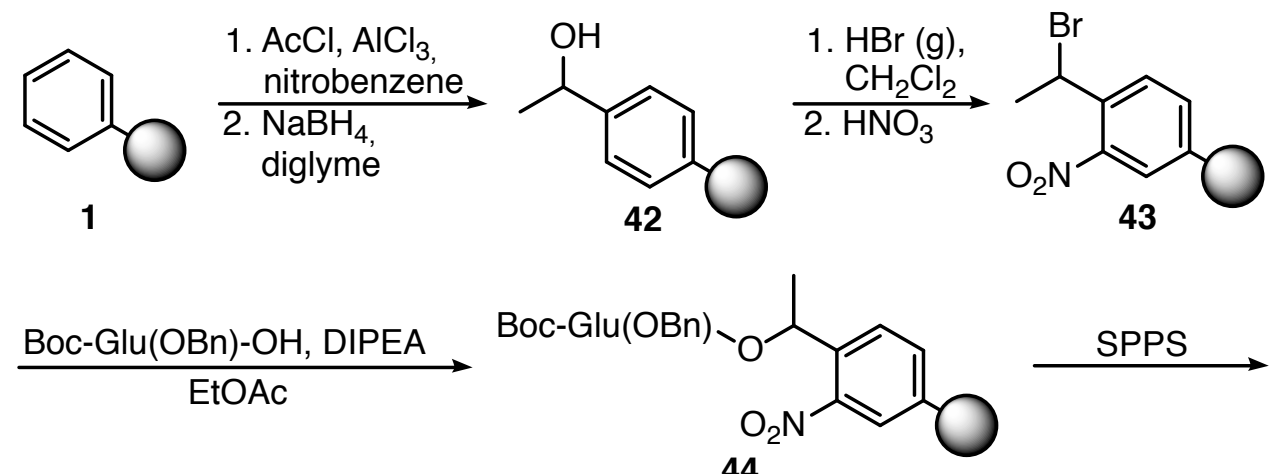

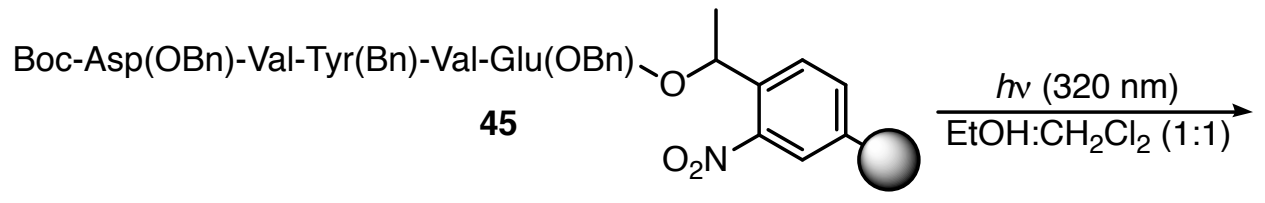

Boc-Asp(OBn)-Val-Tyr(Bn)-Val-Glu(OBn)-OH

46

$40 \%$

: polystyrene resin 


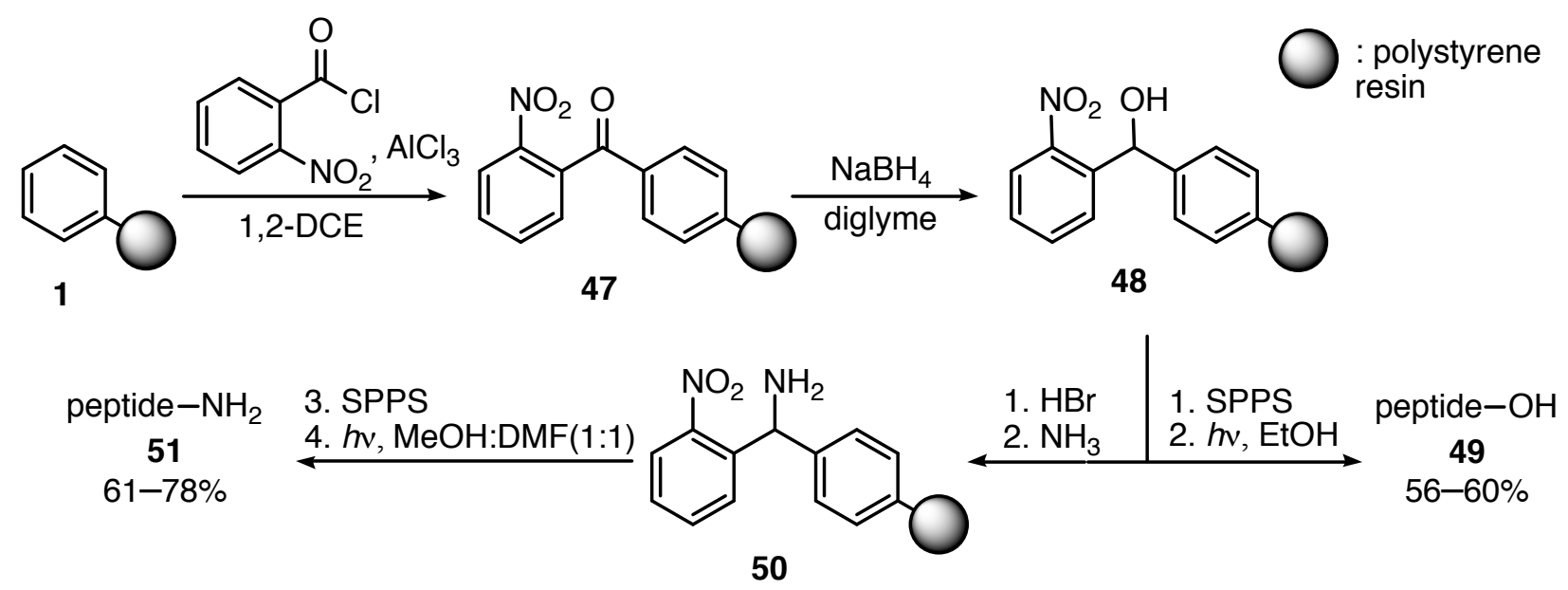




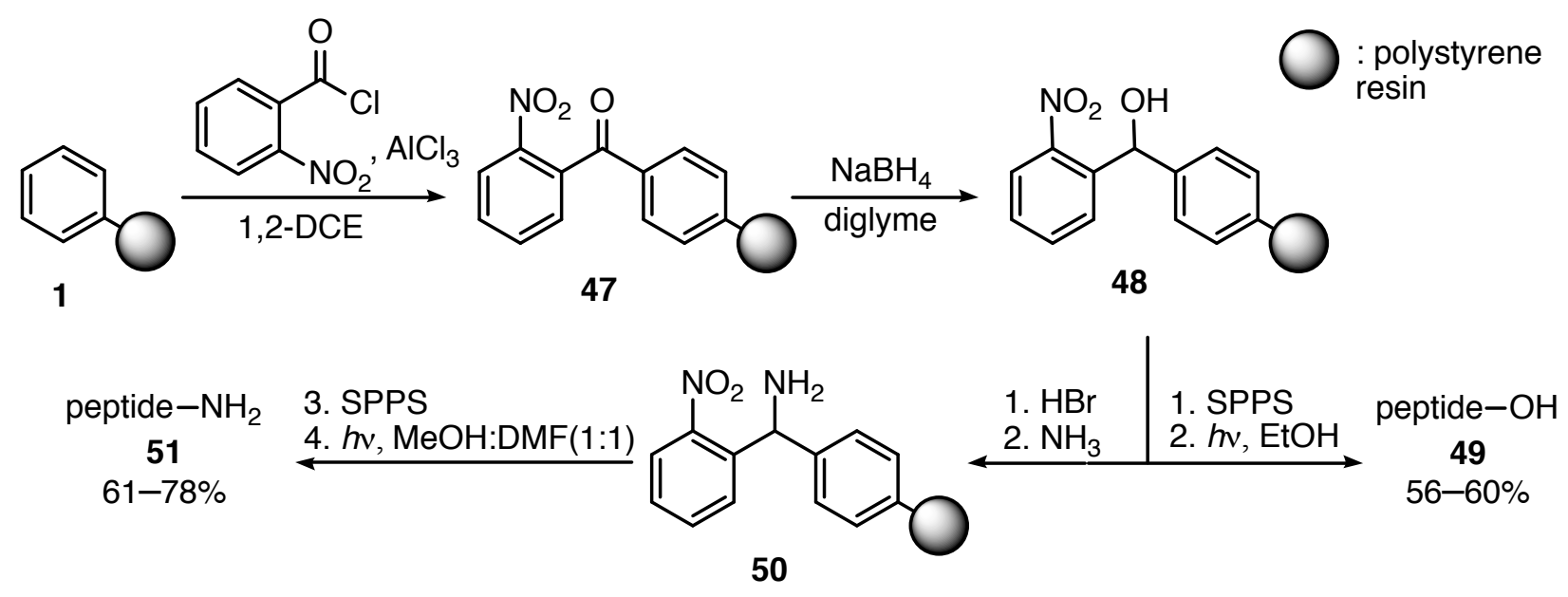


<smiles>CO[N+](=O)[O-]</smiles><smiles>O=C(O)N1C(=O)CCCCC1c1ccccc1[N+](=O)[O-]</smiles><smiles>O=C1CCCCC(c2ccccc2[N+](=O)[O-])O1</smiles>

59<smiles>CC(O)C(O)O</smiles><smiles></smiles>

60: $\mathrm{R}=\mathrm{OH}$

61: $\mathrm{R}=\mathrm{NHBOC}$ 


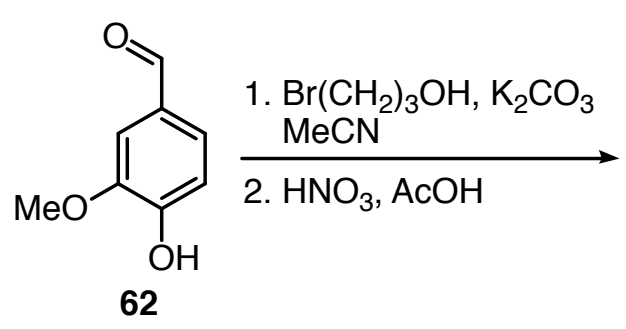

62<smiles>COc1cc(C=O)c([N+](=O)[O-])cc1OCCCOC(C)=O</smiles>

63
1. $\mathrm{K}_{2} \mathrm{CO}_{3}, \mathrm{MeOH}$
2. $\mathrm{TBDMSCl}^{\mathrm{Im}}, \mathrm{DMF}$<smiles>COc1cc(CO)c([N+](=O)[O-])cc1OCCCOC(C)(C)C</smiles>

64 

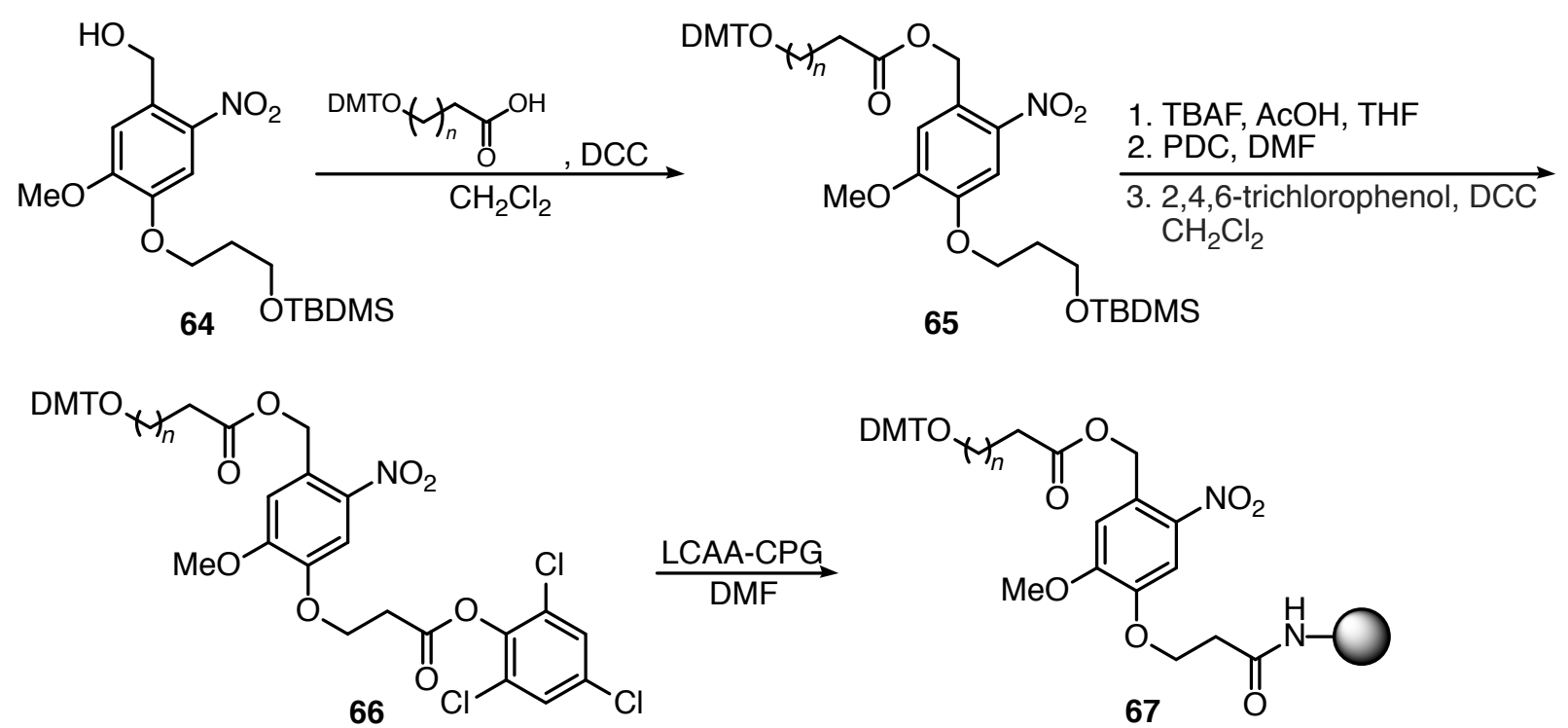

\section{1. oligonucleotide synthesis \\ 2. $h v(400 \mathrm{~nm}), \mathrm{MeCN}: \mathrm{H}_{2} \mathrm{O}(9: 1)$ 3. detritylation $\left(\mathrm{NH}_{4} \mathrm{OH}, \mathrm{aq}\right)$}

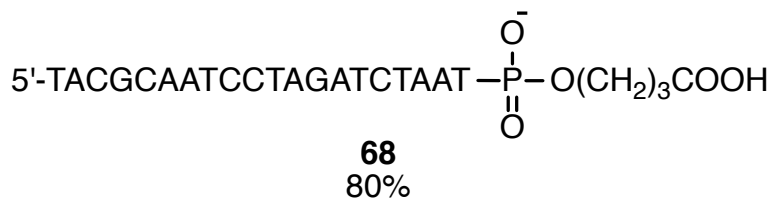



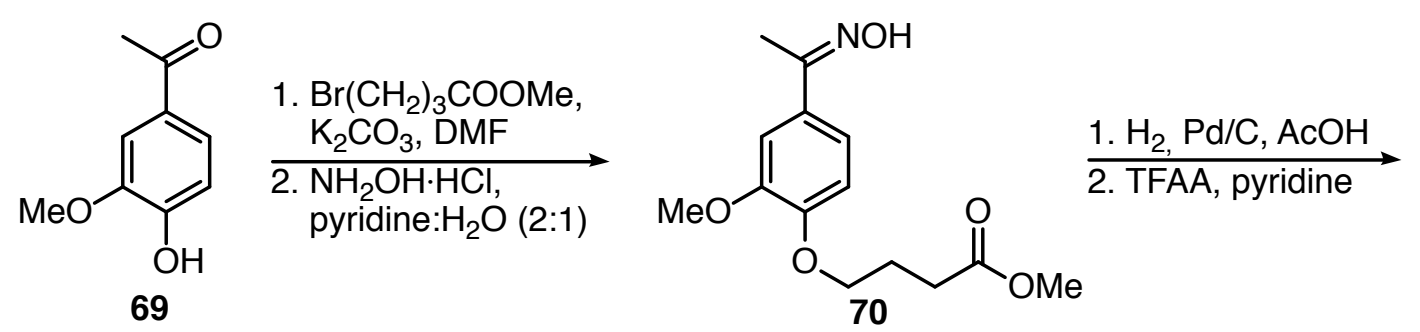<smiles>COC(=O)CC[CH]Oc1ccc(C(C)NC(=O)OC(F)(F)F)cc1OC</smiles><smiles>COC(=O)CCCOc1cc([N+](=O)[O-])c(C(C)NC(=O)OCc2ccccc2)cc1OC</smiles><smiles>COc1cc(C(C)N)c([N+](=O)[O-])cc1OCCCC(=O)O</smiles>

73<smiles></smiles><smiles>COc1cc(C(C)N)c([N+](=O)[O-])cc1OCCCC(=O)NO</smiles>

1. SPPS 2. $h v(365 \mathrm{~nm})$ PBS buffer:DMSO (95:5) H-Met-Gly-Trp-Met-Asp-Phe- $\mathrm{NH}_{2}$
$\mathbf{7 6}$

TentaGel resin 


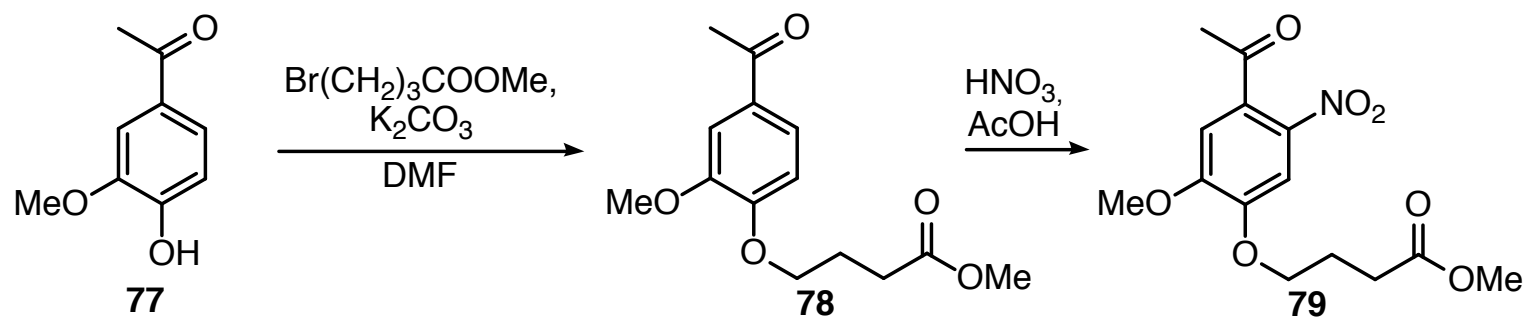<smiles>COC(=O)CC[C@@H](O)Oc1cc([N+](=O)[O-])c(C(C)O)cc1OC</smiles> 
<smiles>COc1cc(C(C)N=CNC(=O)O)c([N+](=O)[O-])cc1OCCCC(=O)Nc1ccc(ON)c([N+](=O)[O-])c1</smiles><smiles>[R]C(N)C(=O)NC(C)c1cc(OC)c(OCCCC(=O)Nc2ccccc2)cc1[N+](=O)[O-]</smiles>

1. $10 \% \mathrm{AcCl}(\mathrm{MeOH})$ 2. $20 \%$ piperidine (DMF)

3. $h v(366 \mathrm{~nm})$, $\mathrm{MeOH}$<smiles>[R]C1NC(=O)C([R7])N(C([R])C(N)=O)C1=O</smiles>

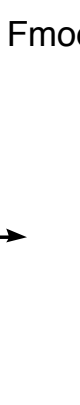

$\mathrm{R}$ :<smiles>CC(C)(C)Cc1ccc([N+](=O)[O-])cc1</smiles>

$\mathrm{R}^{2}$ : amino acid side chain

$\mathrm{R}^{3}$ :<smiles>CC(C)(C)C1=CCCCC1</smiles>

$\mathrm{R}^{4}: \mathrm{Cy}, \mathrm{CH}_{3}\left(\mathrm{CH}_{2}\right)_{5}, \mathrm{Ph}\left(\mathrm{CH}_{2}\right)_{2}$

modified cellulose 

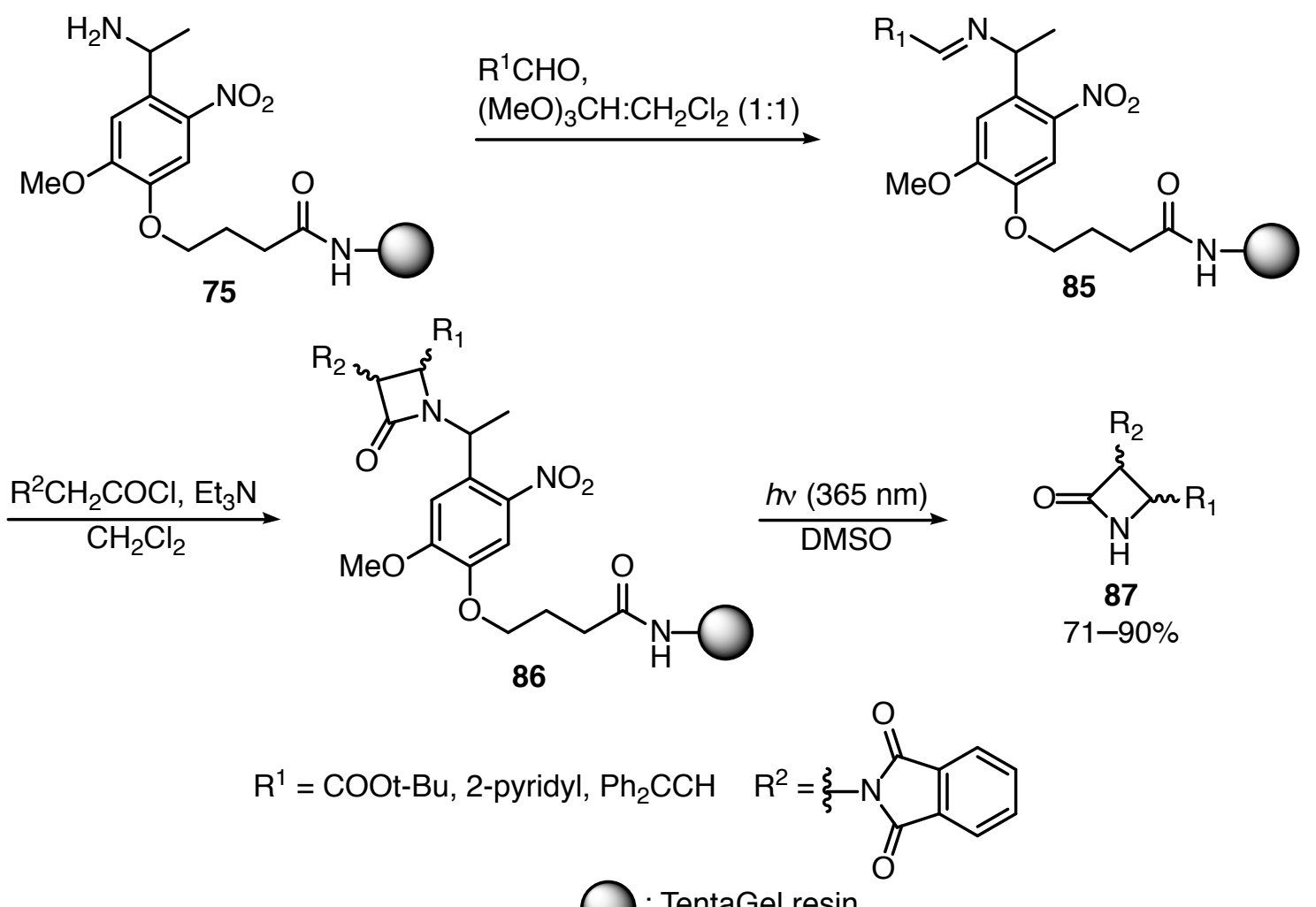


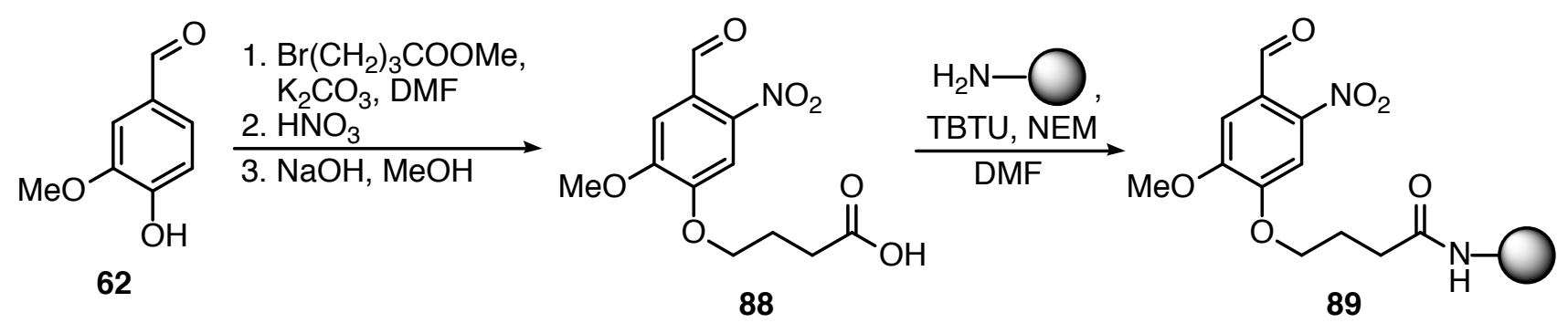<smiles>COc1cc(CNC(=O)CCl)c([N+](=O)[O-])cc1OCCCC(=O)Nc1ccccc1</smiles><smiles>CCN1CCN(CC(=O)NCc2cc(OC)c(OCCCC(=O)NCc3ccccc3)cc2[N+](=O)[O-])CC1</smiles>

$\mathrm{R}^{1} \mathrm{HN}$<smiles>[R7]C(=O)CN1CCNCC1</smiles>

94

$12-35 \%$ 


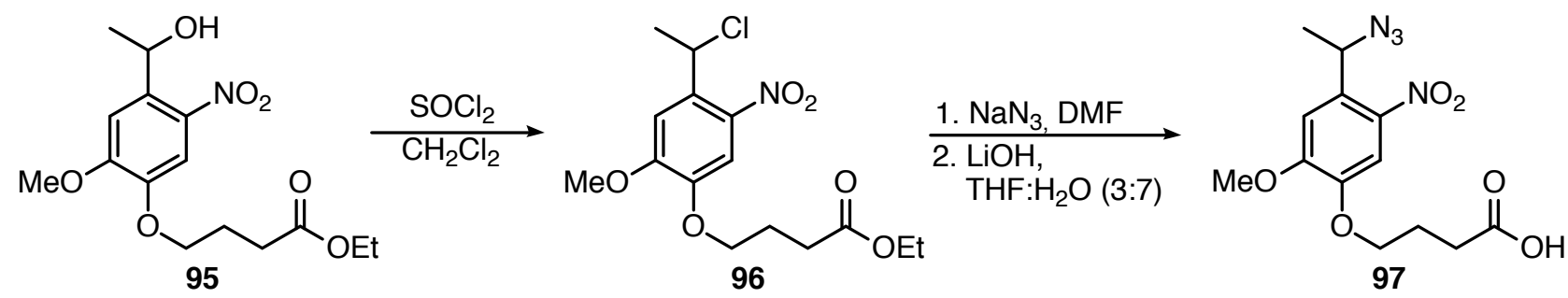<smiles>[R]c1cn(C(C)c2cc(OC)c(OCCCC(=O)Nc3ccc(N)cc3)cc2[N+](=O)[O-])nn1</smiles> 


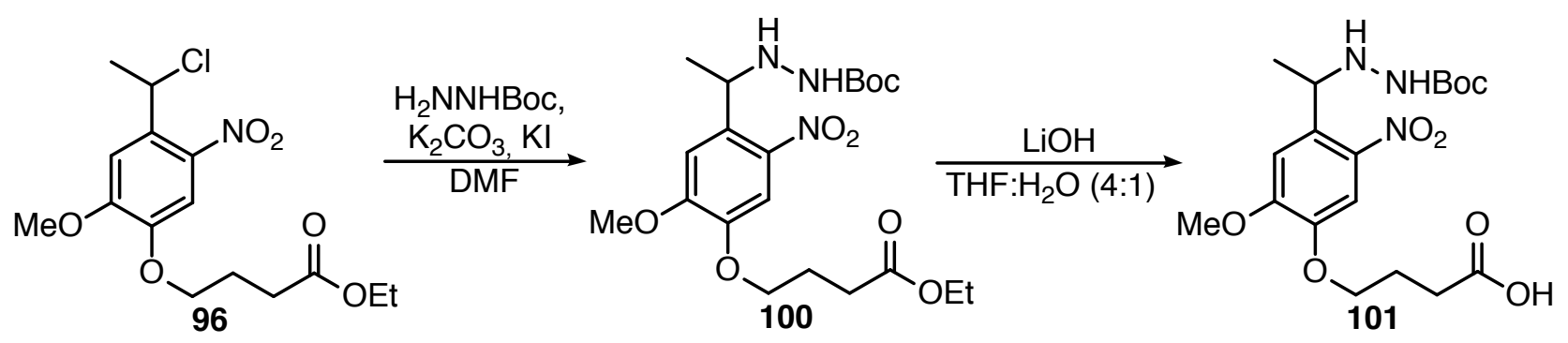

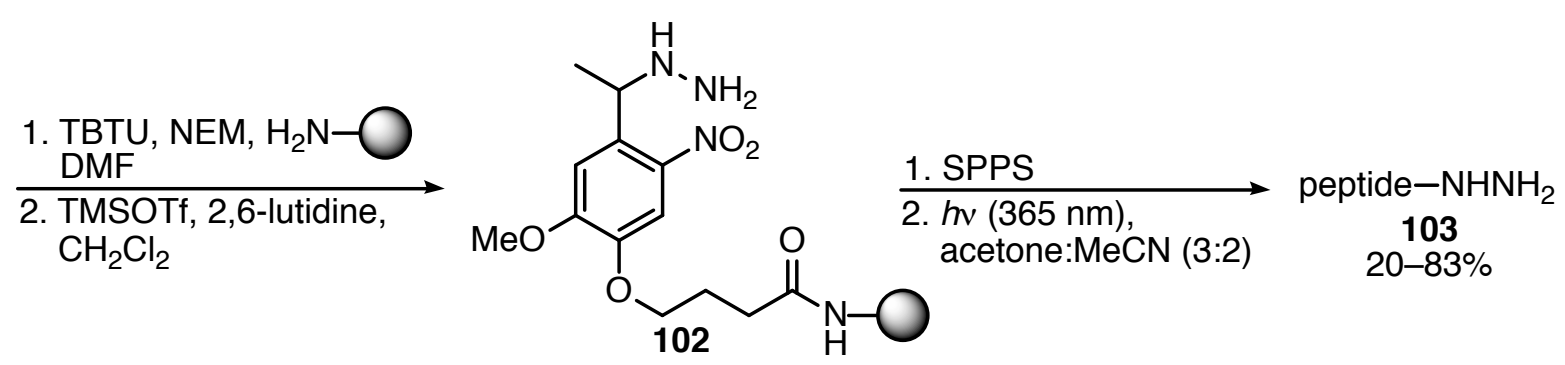

1. TBTU, NEM, $\mathrm{H}_{2} \mathrm{~N}-\mathrm{O}$
$\stackrel{\text { DMF }}{\text { 2. TMSOTf, 2,6-lutidine, }}$

O: ChemMatrix 


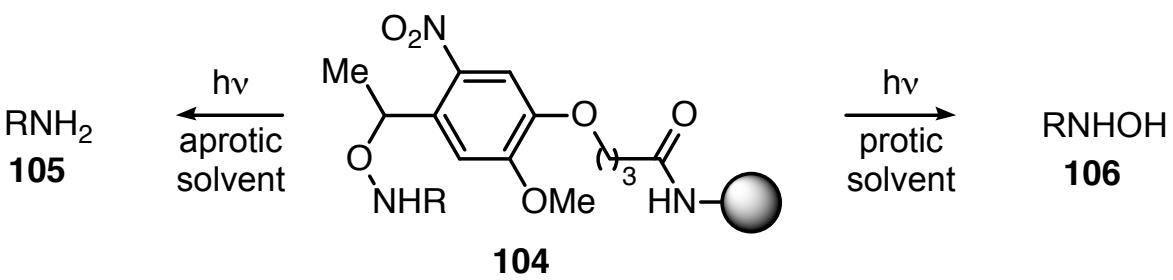




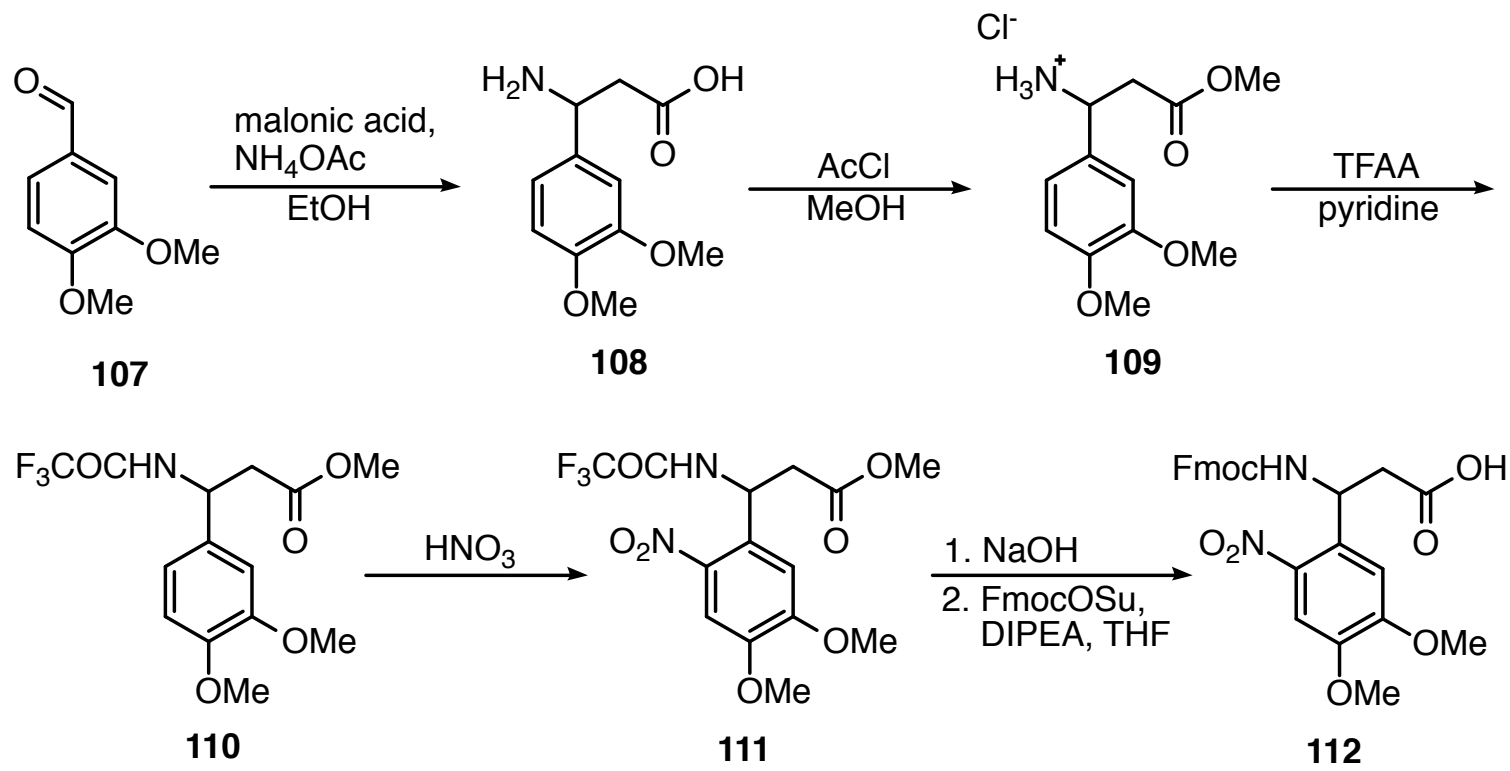

1. $\mathrm{H}_{2} \mathrm{~N}-\mathrm{O}, \mathrm{BOP}, \mathrm{HOBt}$,

\begin{tabular}{lc} 
DIPEA, DMF & H-Tyr-Gly-Gly-Phe-Leu- $\mathrm{NH}_{2}$ \\
\hline 2. SPPS & 113 \\
3. $h v(365 \mathrm{~nm}), \mathrm{MeOH}$ & $50 \%$
\end{tabular}

HiCore resin 


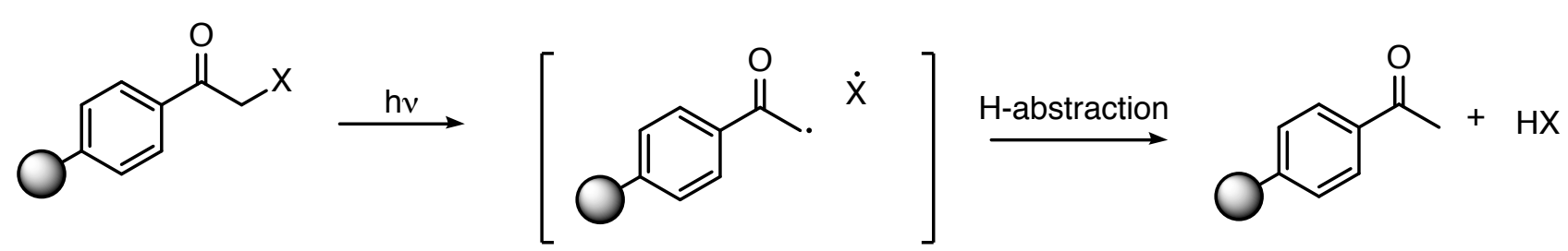

27
28
30
31
32
33
34
35
36
37
38
39
40
41
42
43
44
45
46
47
48
49
50
51
52
53
54
55
56
57
58
59
60




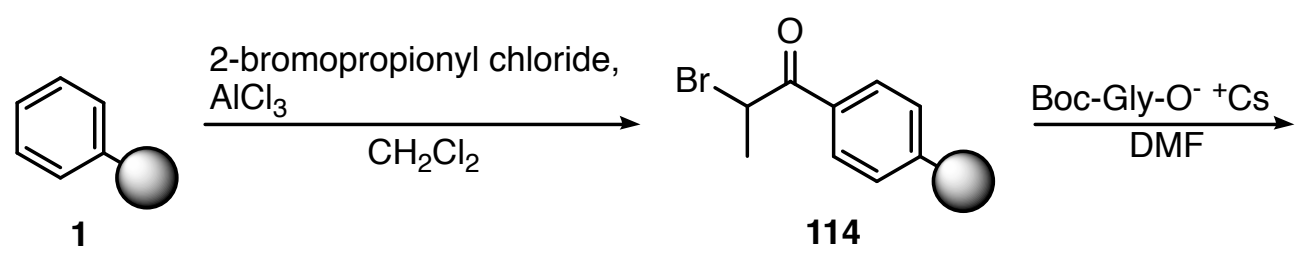<smiles>CC(OC(=O)OC(C)(C)C)C(=O)c1ccc(Oc2ccc([SeH2])cc2)cc1</smiles>

\section{$\stackrel{h v(350 \mathrm{~nm})}{\longrightarrow}$ Z-Lys(Z)-Phe-Phe-Gly-OH DMF
117
$70 \%$}

: polystyrene resin 
<smiles>O=C(O)Cc1ccccc1</smiles>

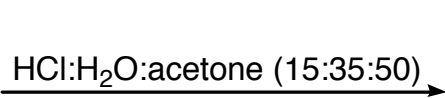<smiles>CC(Br)C(=O)c1ccc(CC(=O)O)cc1</smiles>

120

$\underset{\text { 1. } \mathrm{MeOH}, \mathrm{H}_{2} \mathrm{SO}_{4}}{\text { 2. 2-bromopropionyl chloride, }}$ $\mathrm{AlCl}_{3}, \mathrm{Cl}_{2} \mathrm{CHCHCl}_{2}$<smiles>COC(=O)Cc1ccc(C(=O)C(C)Br)cc1</smiles><smiles></smiles>

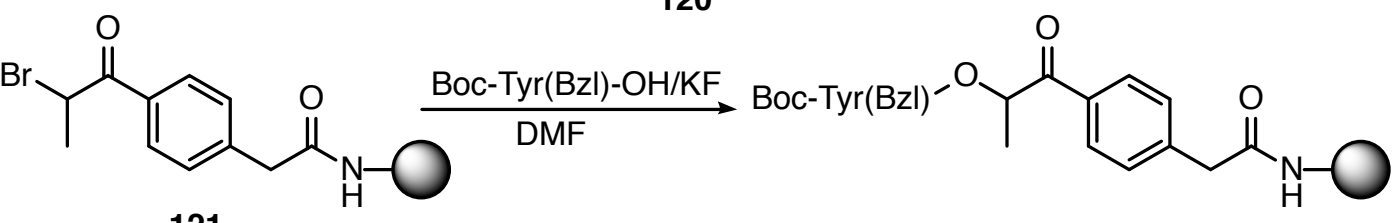

122

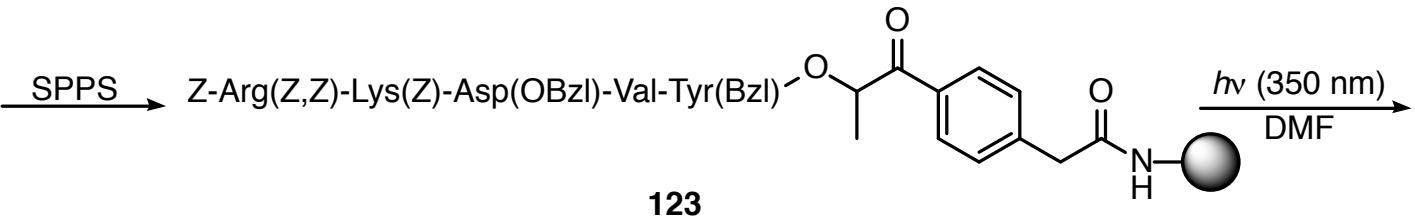

Z-Arg(Z,Z)-Lys(Z)-Asp(OBzl)-Val-Tyr(Bzl)-OH

124

$78 \%$

: aminomethyl resin 
<smiles>CC(Br)C(=O)c1ccc(OCC(=O)OCc2ccccc2)cc1</smiles><smiles>CCCOc1ccc(C(=O)C(C)Br)cc1</smiles><smiles>CC(OC(C)(C)C)C(=O)c1ccc(OCC(=O)NCc2ccccc2)cc1</smiles>

1. SPPS

2. $h v(350 \mathrm{~nm}), \mathrm{DMF}$ H-Tyr-Gly-Gly-Phe-Leu-OH

3. deprotection 


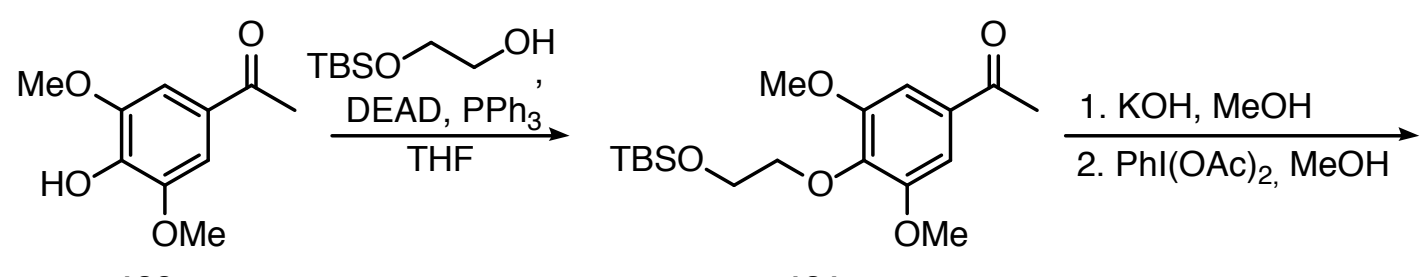

130

131<smiles>COc1cc(C(CO)(OC)OC)cc(OCCO)c1OCC(=O)OCC(C)c1ccccc1[N+](=O)[O-]</smiles>

132

133<smiles>CC(C)N(C(C)C)P(Cl)OCCC#N</smiles><smiles>COc1cc(C(C)(COC(=O)OCC(C)c2ccccc2[N+](=O)[O-])OC)cc(C)c1OCCOP(I)OCCC#N</smiles><smiles>Oc1ccccc1</smiles>

134<smiles>COc1cc(C(COC(=O)OCC(C)c2ccccc2[N+](=O)[O-])(OC)OC)cc(OC)c1Oc1ccccc1</smiles>

135<smiles>COc1cc(C(CONC#N)(OC)OC)cc(OC)c1Oc1ccccc1</smiles>

136<smiles></smiles>

137

monohydroxy glass slide 
<smiles>COC(=O)Cc1c(OC)cccc1OCCOC(=O)Cc1cc(C(=O)C(C)Br)ccc1OC</smiles>

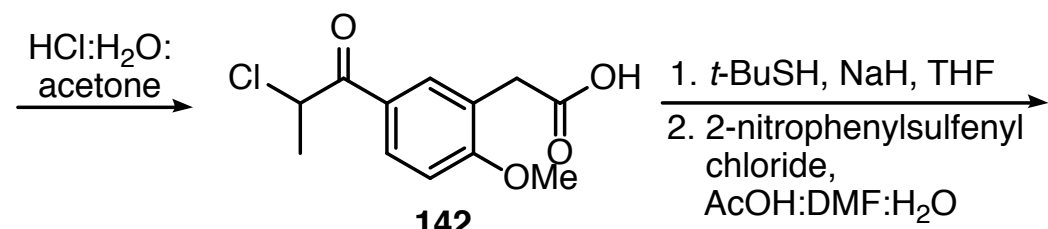<smiles>COc1ccc(C(=O)C(C)SSc2ccccc2[N+](=O)[O-])cc1CC(=O)O</smiles>

143<smiles>COc1ccc(C(=O)C(C)SSc2ccccc2[N+](=O)[O-])cc1CC(=O)Nc1ccc(N)cc1</smiles>

144<smiles>COc1ccc(C(=O)C(C)SCc2ccc(I)cc2)cc1CC(=O)NCOc1ccccc1</smiles><smiles>Cc1ccc(-c2ccccc2)cc1</smiles> 


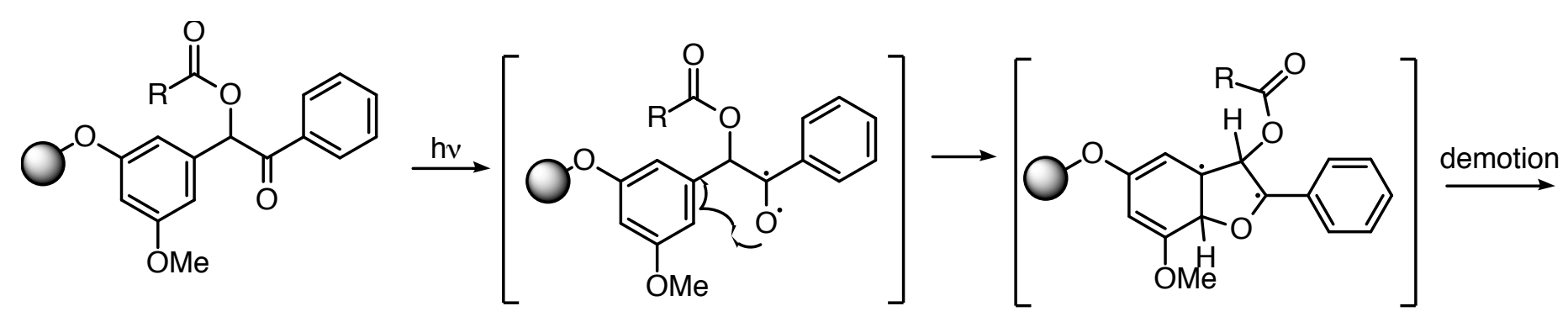

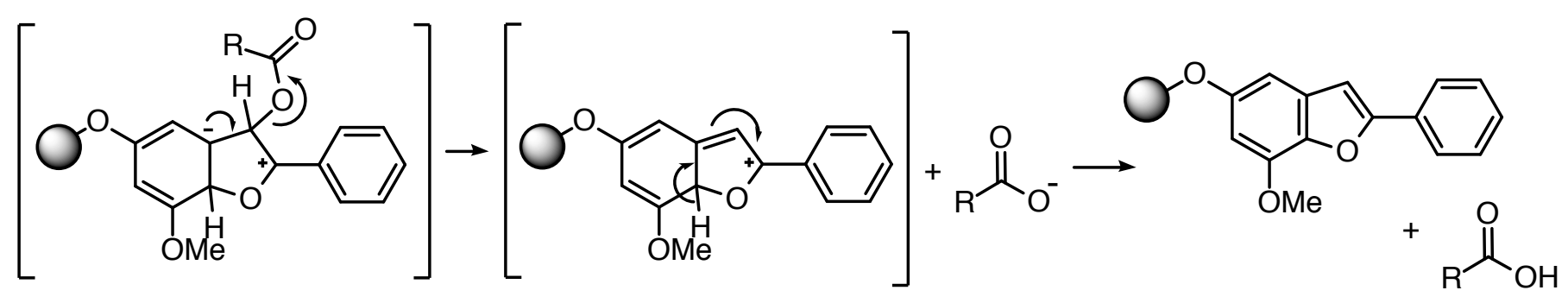




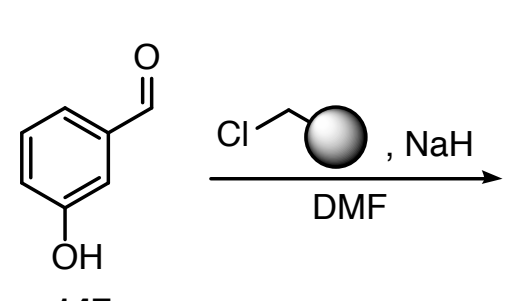

147

Fmoc- $\beta$-Ala-OH, DIC, DIPEA, HOBt, DMAP DMF<smiles>O=C(CCNC(=O)OC(c1cccc(OCc2ccccc2)c1)C1(P)SCCCS1)Oc1ccccc1</smiles>

150<smiles>CC(F)C1SCCCS1</smiles>

148<smiles>OC(c1cccc(OCc2ccccc2)c1)C1(P)SCCCS1</smiles>

149<smiles>O=C(CCNC(=O)OC(C(=O)c1ccccc1)c1cccc(OCc2ccccc2)c1)OCc1ccccc1</smiles>

151 $h v(350 \mathrm{~nm}) \quad$ Fmoc- $\beta$-Ala-OH $\overrightarrow{\mathrm{THF}}: \mathrm{MeOH}(3: 1) \quad 152$ $98 \%$

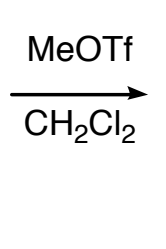

: Merrifield resin 
<smiles>COc1cc(O)cc(C=O)c1</smiles>

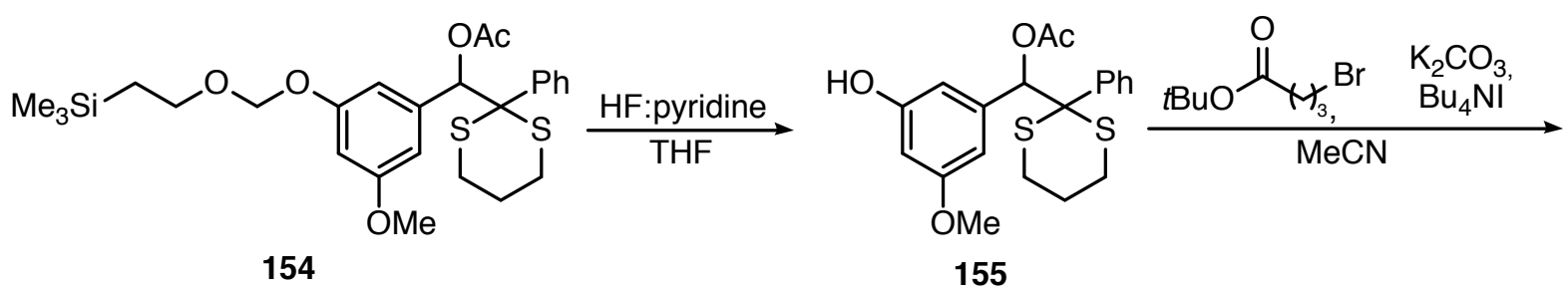<smiles>CCNC(C)(C)OC(=O)C(C)(C)Oc1cc(OC)cc(C(O)C2(c3ccccc3)SCCCS2)c1</smiles>
156 157<smiles>COc1cc(OC)cc(C(O)C2(c3ccccc3)SCCCS2)c1</smiles>
158 
<smiles>CCCCOC(=O)c1cccc(C2(C(OC(C)(C)C)c3cc(OC)cc(OC)c3)SCCCS2)c1</smiles>

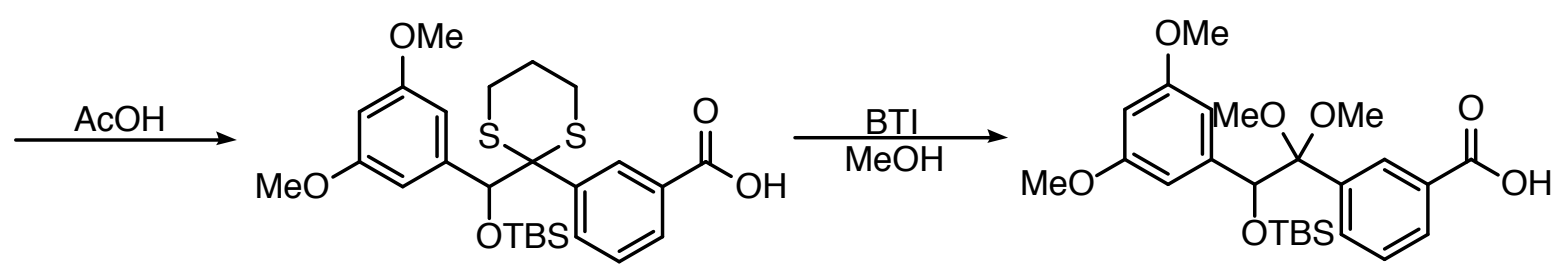

163

164

1. $\mathrm{H}_{2} \mathrm{~N}-\bigcirc$, PyAOP, HOAt,

DIPEA, DMF

2. SPPS

3. $h v, \mathrm{MeOH}: \mathrm{H}_{2} \mathrm{O}(3: 7)$

H-Lys-Tyr-Arg-Arg-Arg-Pro-Arg-Arg-Ser-GIn-Arg-Lys-Arg-Gly-OH 165

TentaGel resin

BTI: [bis(trifluoroacetoxy)iodo]benzene 


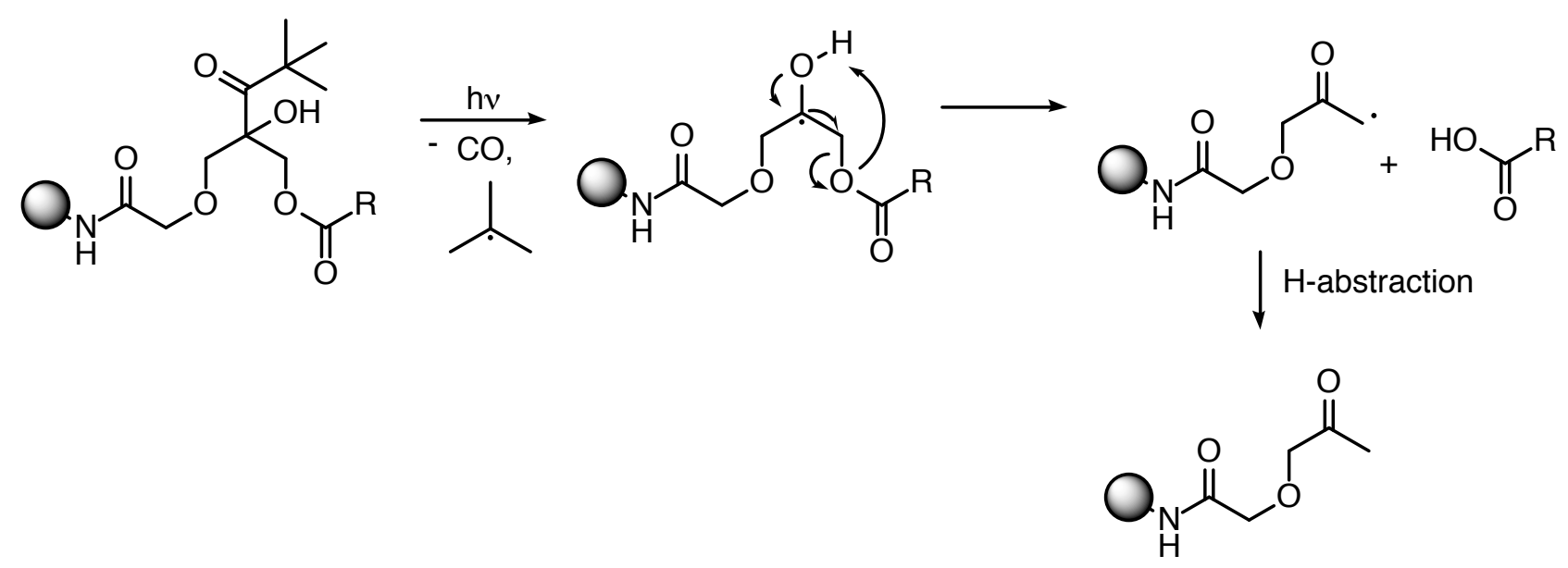




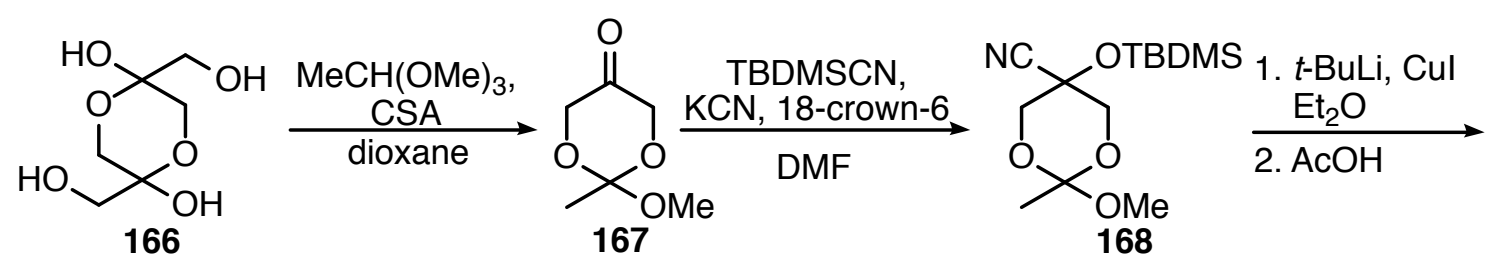<smiles>CC(=O)OCC(CO)(OC(C)=O)C(=O)C(C)(C)C</smiles>

169<smiles>C[R15](=O)OCC(O)(COCC(=O)OC(C)(C)C)C(=O)C(C)(C)C</smiles>
170<smiles>CCCCOCC(COCC(=O)O)(C(=O)C(C)(C)C)C(C)(C)C(=O)COCC(O)(CO)C(=O)C(C)(C)C</smiles><smiles>CC(C)(C)C(=O)C(O)(COCC(=O)Nc1ccccc1)C(=O)C(C)(C)C</smiles>

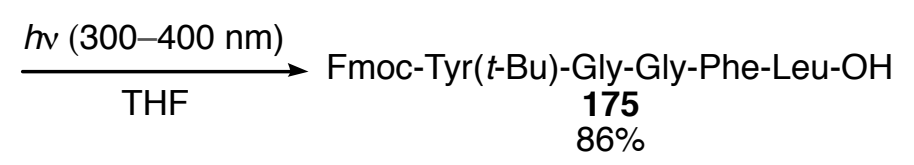

: TentaGel resin 


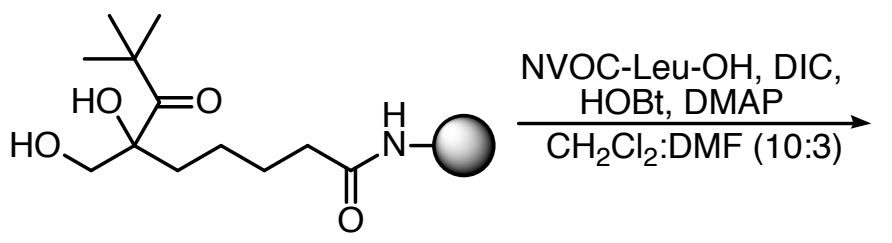

176

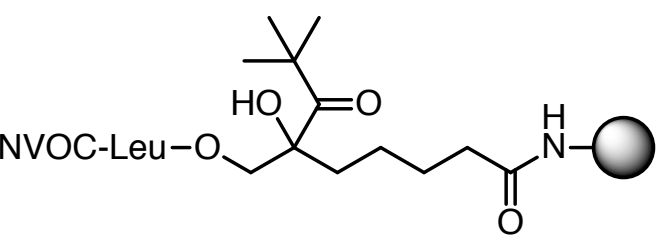

177

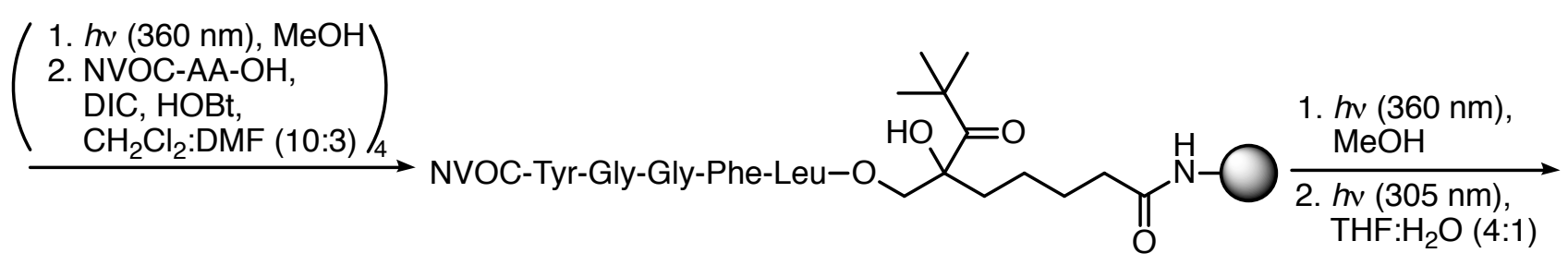

178

H-Tyr-Gly-Gly-Phe-Leu-OH

179

$55 \%$

TentaGel resin 


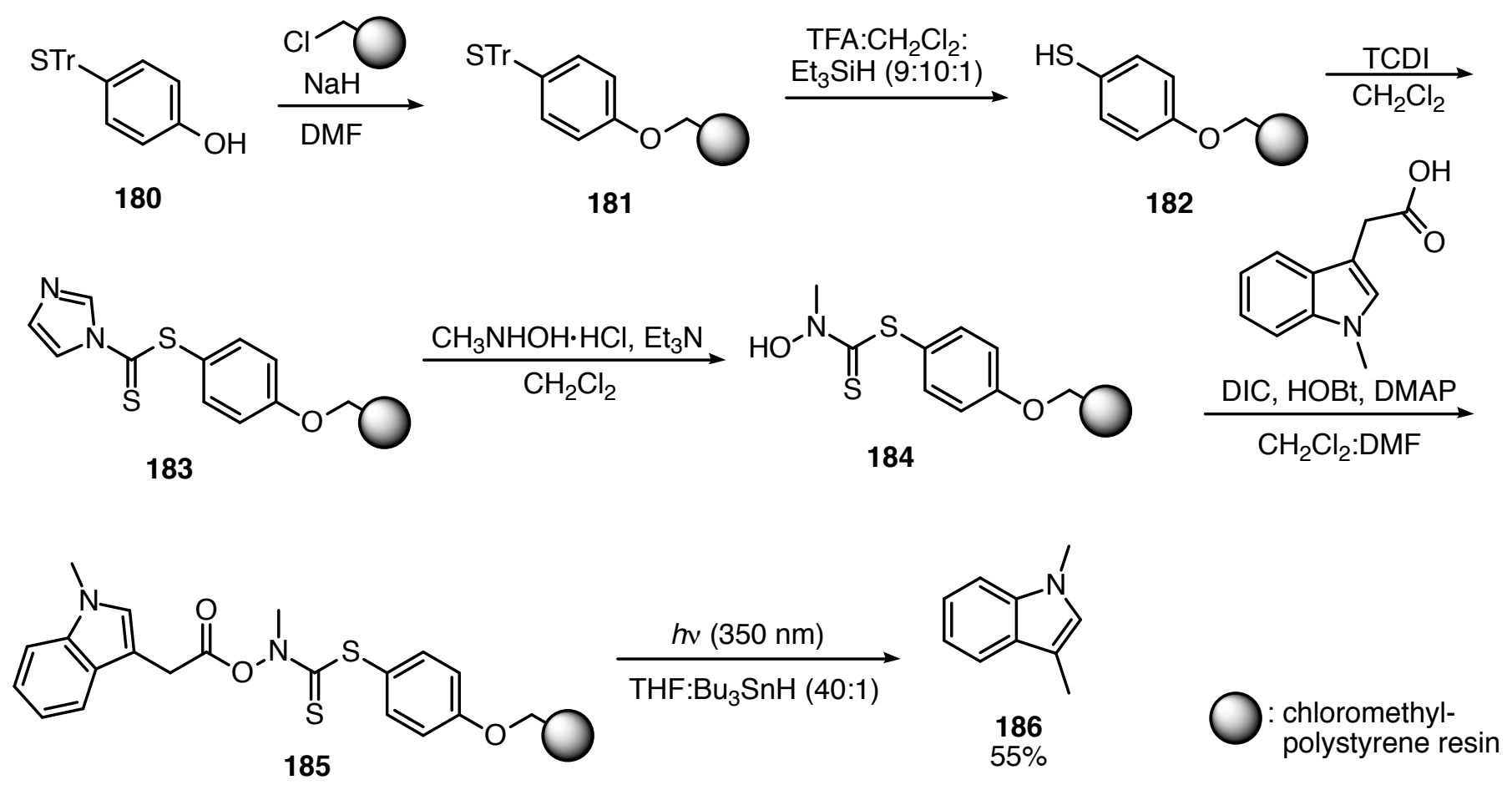




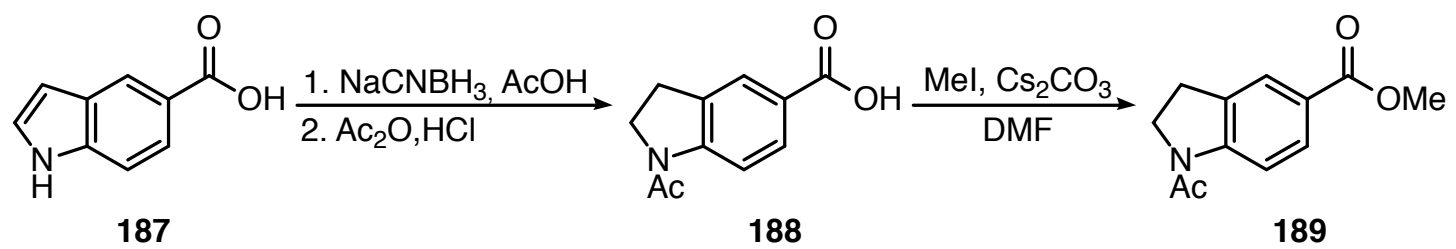

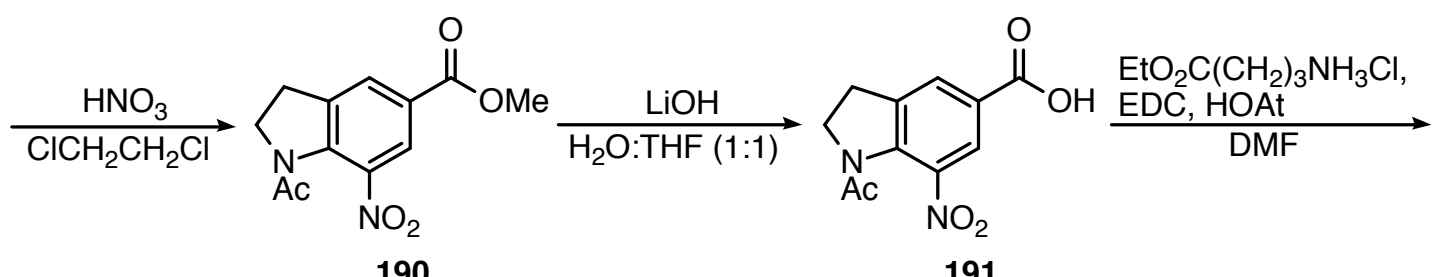<smiles>CCOC(=O)CCCNC(=O)c1cc2c(c([N+](=O)[O-])c1)NC(CO[C@H]1Cc3cc(C(=O)NCCCC(=O)OCC)cc([N+](=O)[O-])c3N1)C2</smiles>

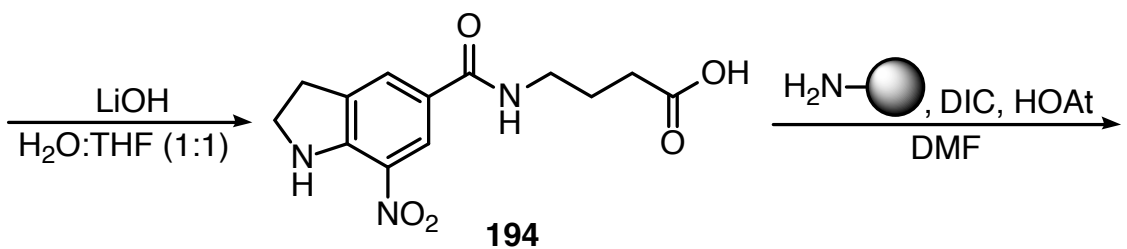<smiles>CC(C)CCC(=O)Nc1ccc(NC(=O)CCCNC(=O)c2cc3c(c([N+](=O)[O-])c2)NCC3)cc1</smiles>

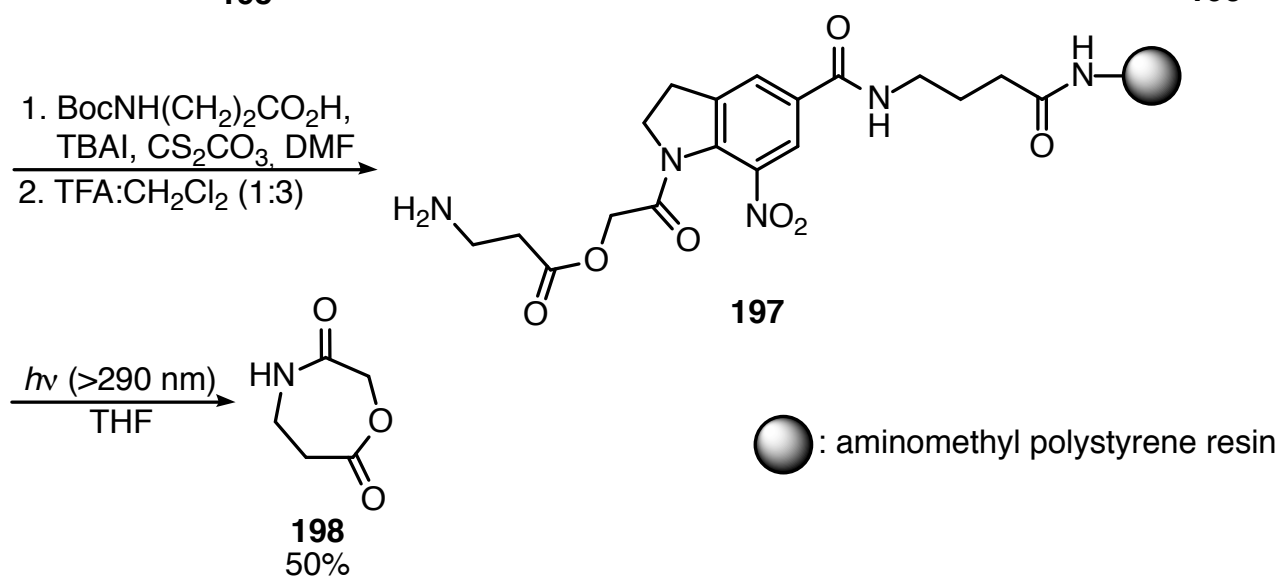




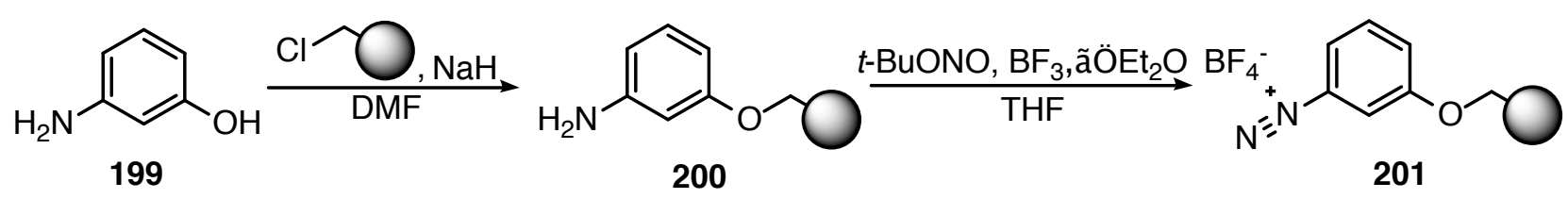<smiles>O=C(C1CCC(C(Cl)(Cl)Cl)CC1)N1CCN(N=Nc2cccc(OCc3ccccc3)c2)CC1</smiles>

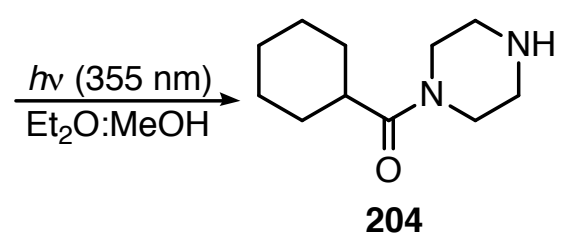

: Merrifield resin 


\section{o-Nitrobenzyl linkers}

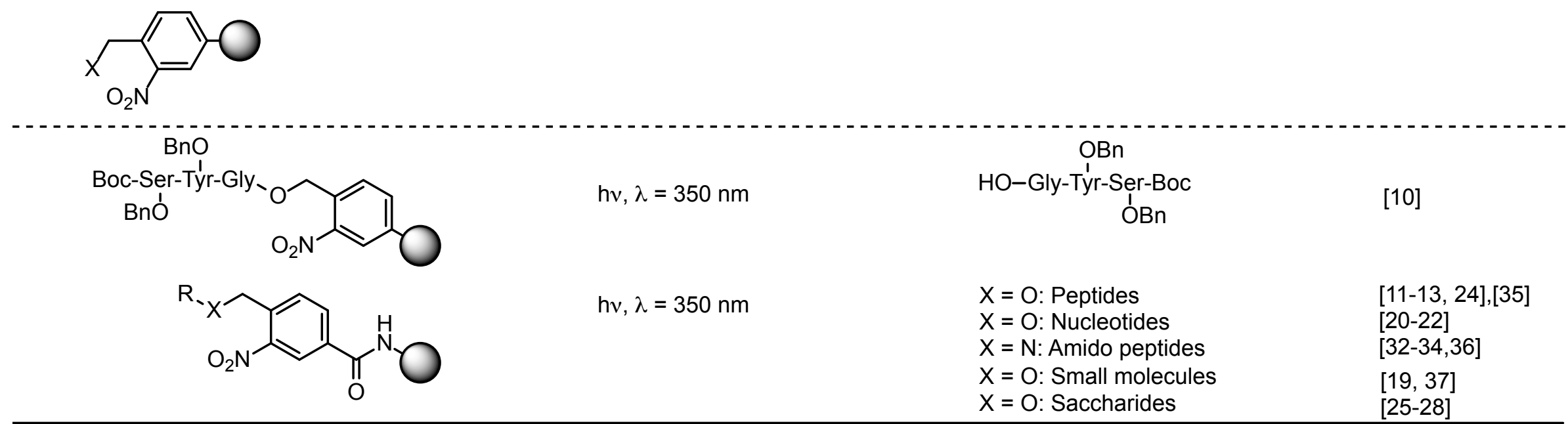

o-nitrobenzyl linkers
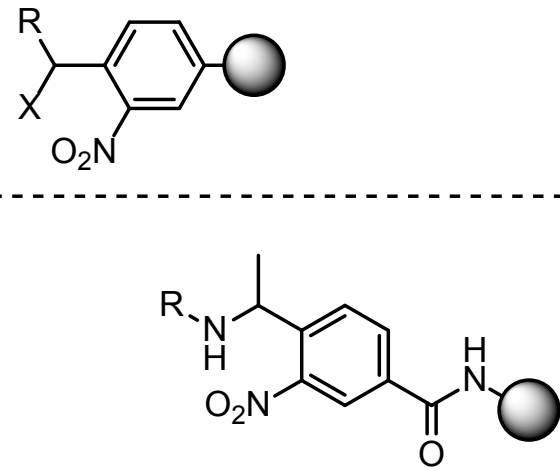

$\mathrm{h} v, \lambda=350 \mathrm{~nm}$

Amido peptides

Glycosaminoglycans

[38-40]<smiles>CCOPOC(c1ccc(OCC)cc1)c1ccccc1[N+](=O)[O-]</smiles>

Peptides

[41]

$\mathrm{h} v, \lambda=350 \mathrm{~nm}$

\section{o-Nitroveratryl linkers}
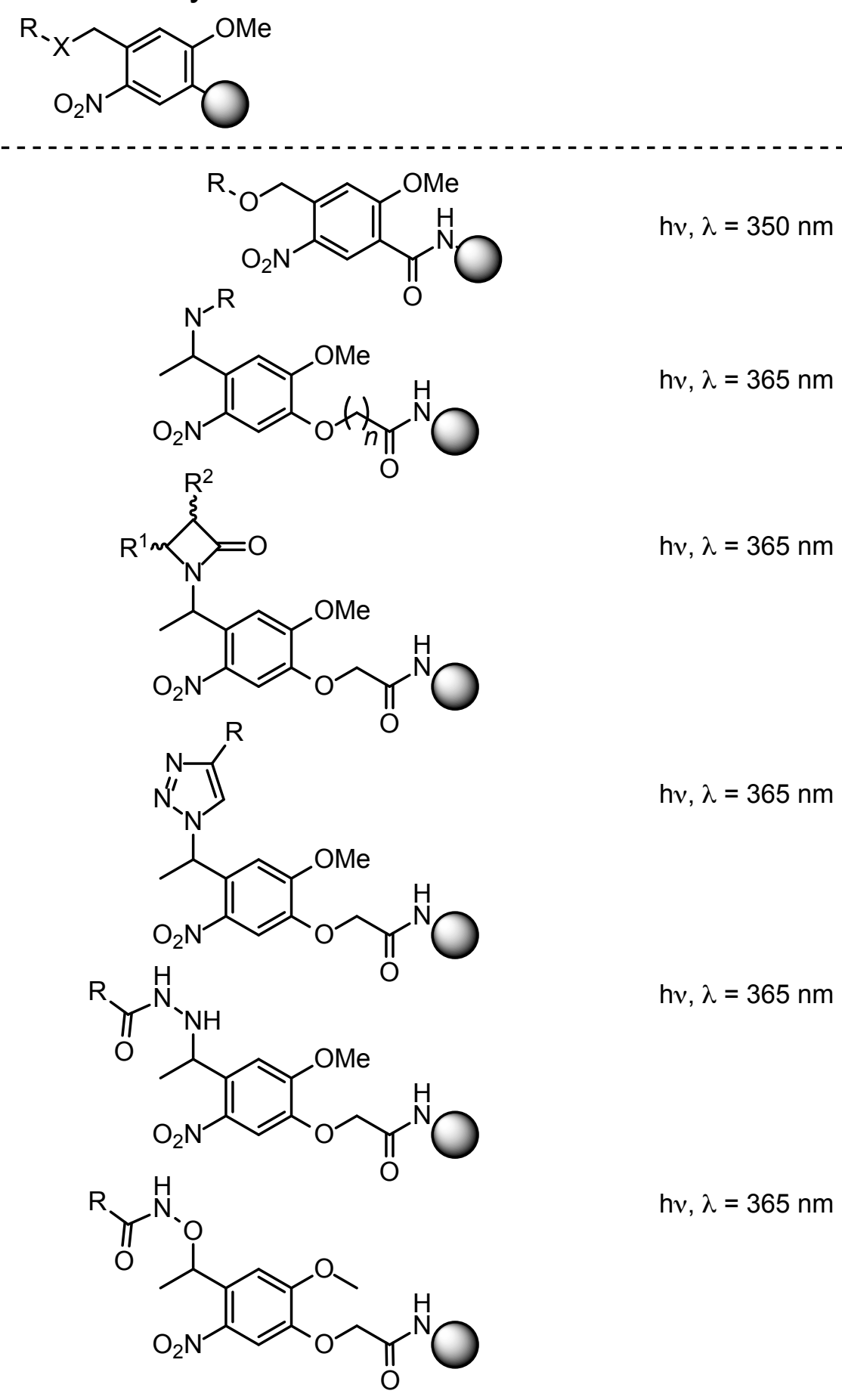

Nucleotides

Saccharides

Amido peptides

Sulfonamidopeptides

[50]

[59]<smiles>[R]C1NC(=O)C1[R]</smiles>

[60]<smiles>[R]c1c[nH]nn1</smiles><smiles>[R]C(=O)NN</smiles><smiles>[R]C(=O)NO</smiles> 
Page 103 of 104

ACS Combinatorial Science

Linker

Cleavage

Product

$\underline{\text { References }}$

Conditions

Phenacyl linkers
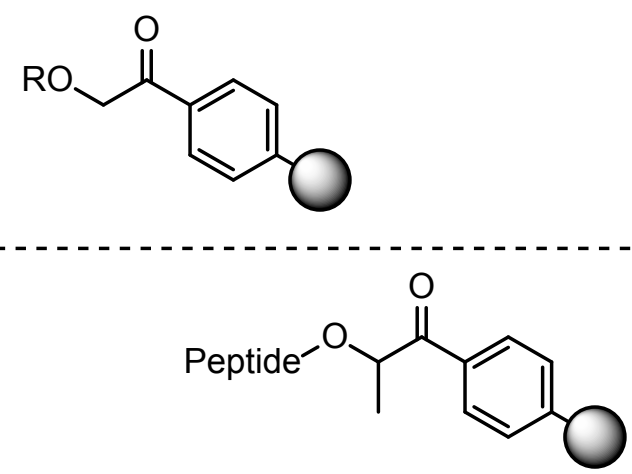

$\mathrm{h} v, \lambda=300-350 \mathrm{~nm}$

Peptides

[67-69]

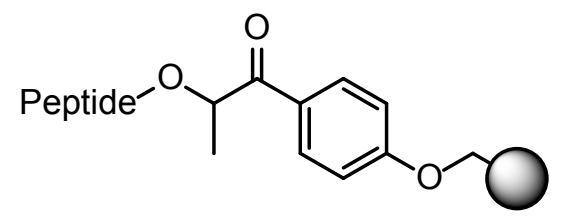

$\mathrm{h} v, \lambda=350 \mathrm{~nm}$

Peptides

[70-71]

Benzoin linkers
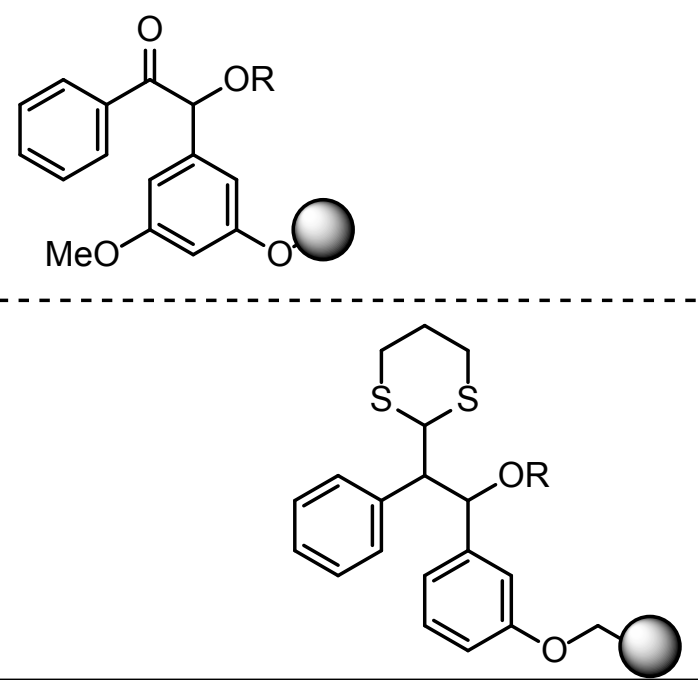

$\mathrm{h} v, \lambda=350 \mathrm{~nm}$

Unnatural amino acids

Pivaloyl linkers
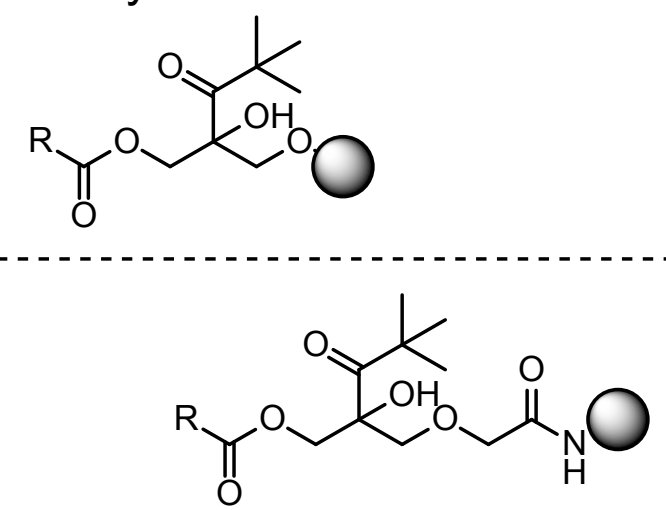

$\mathrm{h} v, \lambda=280-340 \mathrm{~nm}$

Peptides

Small molecules

$[80,82]$

[81]

Other photolabile linkers

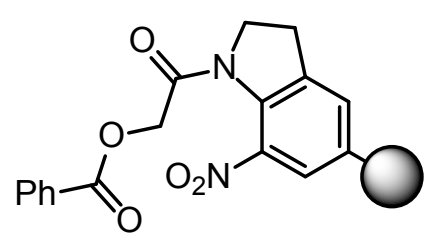

$\mathrm{h} v, \lambda=290 \mathrm{~nm}, \mathrm{R}^{1} \mathrm{R}^{2} \mathrm{NH}$<smiles>[R]N([R])C(=O)COC(=O)c1ccccc1</smiles>

[84]

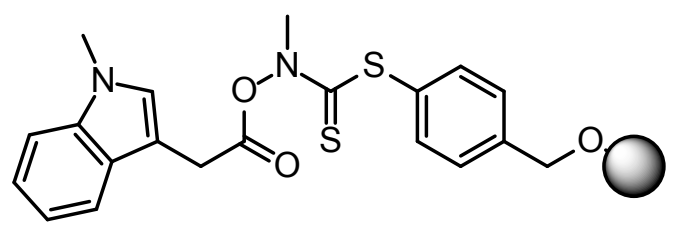

$\mathrm{hv}, \lambda=350 \mathrm{~nm}$, $\mathrm{Bu}_{3} \mathrm{SnH}, \mathrm{THF}$

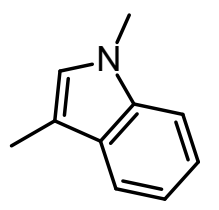

[83)

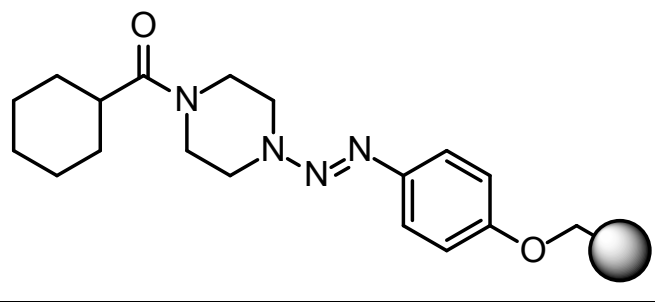

$\mathrm{h} v, \lambda=355 \mathrm{~nm}$

(N)

[85)

ACS Paragon Plus Environment 
Photolabile Linkers for Solid-Phase Synthesis

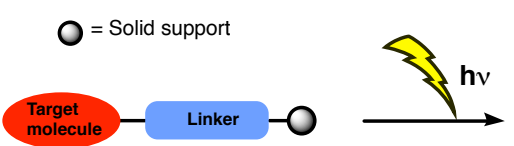

